\title{
WORTELS EN GRONDWOORDEN IN DE AUSTRONESISCHE TALEN.
}

DOOR

R. A. KERN.

\section{Inleiding.}

't Kenmerkende van den woordenschat der Austronesische talen zijn de tweelettergrepige grondwoorden en de éénlettergrepige formatieven. Een grondwoord is die vorm van het woord welke geen verdere ontleding in samenstellende, zelfstandige deelen toelaat, het is het woord, ontdaan van alle daaraan gehechte affixen, het woord in zijn grondvorm. Het kan zonder meer als rededeel optreden, dit is bijvoorbeeld met substantieven het geval: $\mathrm{rumah}$ - huis, la n g i t hemel, enz.. 't Komt ook voor dat het grondwoord nooit alleen gebruikt wordt doch alleen van een affix voorzien, de beteekenis ligt dan, als het ware, in het grondwoord omsluierd en komt eerst te voorschijn in verbinding met een, zijn eigen vormende kracht aan het grondwoord toevoerend formatief. Dit kan zich bij werkwoorden voordoen: Mal. ba ja $r$ is slechts grondwoord, $\mathrm{mambajar}-$ betalen, b a j a r a n - betaling, enz.

Er zijn ook meerlettergrepige grondwoorden, bij dezen is het doorgaans gemakkelijk een scheiding tusschen een oorspronkelijk, tweelettergrepig grondwoord en een niet meer als zoodanig gevoeld of beschouwd affix (of affixen) te maken ${ }^{1}$ ), 't zijn dus secundaire grondwoorden, bv. Jav. bakamal - gezouten = prefix ba, in het Javaansch verloren gegaan, $+\mathrm{k}$ a mal - ingezouten, v. eieren.

1) Het woord „beschouwd" kan hier niet gemist worden. 't Komt wel voor dat men een grondwoord, blijkens de daarvan gemaakte afleidingen, kent en niettemin één afleiding tot een nieuwgemaakt grondwoord terugbrengt, bv. van Soend. i $1 \mathrm{u}, \mathrm{gw}$. van ,mede [gaan, doen, enz.], worden verschillende afleidingen gemaakt, doch milu (um - + il u wordt tot een valschen stam pilu teruggebracht. Dit is geen onwetendheid maar een analogie-verschijnsel. Immers, een begin-consonant $p$ wordt in den actieven werkwoordsvorm $m$, omgekeerd wordt $m$ van $\mathrm{mil} \mathrm{u}$, dat ook actief is, terugherleid tot $p$. 
Door combinatie kunnen twee- en meerlettergrepige formatieven ontstaan: $\mathrm{pa}+\mathrm{k}$ a levert $\mathrm{paka-}, \mathrm{mag}+\mathrm{si}+\mathrm{pag}$ levert $\mathrm{mag}$ s i p a g- (Tag), enz.

In de meeste gevallen is in een grondwoord een éénlettergrepige kern te onderscheiden, welke hetzij door affigeering, hetzij door herhaling of reduplicatie, hetzij door vóórvoeging van een syllabe tot grondwoord is geworden, in het laatste, meest voorkomende geval, zoo ook in het tweede geval, is dus de tweede syllabe die kern, welke wortel genoemd wordt. Vergelijkt men de grondwoorden met zelfden wortel, dan blijken de beteekenissen dezer woorden verwant te zijn, de beteekenis van een woord ligt dus in hoofdzaak in den wortel. Hierbij is in aanmerking te nemen dat er homonyme wortels zijn.

Voorbeelden. In den wortel $\mathrm{dj} \mathrm{u} \mathrm{r}$, in het Soendaasch ook zelfstandig als umpak basa optredende, in het Javaansch z.v.a. ĕ d j u r het verbrijzeld, vermorzeld worden, het in water opgelost worden of smelten, ligt de beteekenis ,,vloeien, stroomen, aldoor in dezelfde rich,ting doorgaan, vervloeien” en van daar ,te niet gaan”, hiermee samengestelde grondwoorden zijn: Soend. a d j u r - vergruisd, gesmolten, tot pap geworden, vloeibaar, a nd j u r - hoosvat, b and j ur overgíeten, b.v. de handen met water, $1 \mathrm{adj} \mathrm{ur}$ - aan iets den vrijen loop laten, $\mathrm{djudjur}$ (met reduplicatie) $=1 \mathrm{adjur}, \mathrm{kudjur}$ de volle lengte van het lichaam, liggende, $\mathrm{udjur}$ - in het lang. De wortel pěl, ook in het Soend. umpak basa, beteekent ,aaneen,,sluitend, dicht opeen”, grondwoorden met dezen wortel zijn: Soend. t a p ěl - grens, vastgehecht zitten (n a pĕ l), du m pěl - een gat dichtmaken, ergens een stop opdoen, toemaken, kĕmpĕ 1 - dicht opeen hangen, v. vruchten enz., ki m pěl - stollen, s u mpěl - stop, kurk, $\mathrm{t} \mathrm{j}$ ĕp ĕl - zich licht hechtend, $\mathrm{p}$ ě $\mathrm{p}$ ĕ 1 - dicht met korrels bezet, v. e. aar, geheel vol, v. e. peulvrucht. (Hier en verder worden alleen de g.w. genoemd)).

't Gelukt niet altijd den wortel te vinden. 't Komt voor dat een aantal grondwoorden de tweede lettergreep gemeen hebben zonder dat de beteekenis hiervan zich laat vaststellen noch de beteekenis dier grondwoorden of een deel ervan iets gemeenschappelijks heeft. Om een enkel voorbeeld te noemen. De volgende woorden hebben in het Soendaasch als-tweede lettergreep ka: ka ka - oudere broeder, door herhaling van $\mathrm{k}$ a gevormd, waaraan dus dezelfde beteekenis schijnt te moeten worden toegekend. Maar dan: buka - openen, ba n g k a - van zelf gestorven, b ung ka - zekere vergiftige slang, 
a $\mathrm{ng} \mathrm{k} \mathrm{a} \mathrm{-} \mathrm{duchten,} \mathrm{d} \mathrm{a} \mathrm{n} \mathrm{g} \mathrm{ka} \mathrm{-} \mathrm{zich} \mathrm{tot} \mathrm{iets} \mathrm{voorbereiden,} \mathrm{d} \mathrm{ja} \mathrm{ng} \mathrm{ka}$ - passer, drievoet, la ka - een houtsoort, la ng ka - zelden, tĕk a t ĕk a - diamantkever, t jika - maagkramp, t j ikat jika - vuurvlieg, t juka - azijn, waka - doorgaan, voortgang hebben, $1 \mathrm{ika}$ een zoetwatervisch, $\mathrm{nan} \mathrm{g} \mathrm{k}$ a - een vruchtboom en zijn vrucht, $\mathrm{r}$ u ka - uit elkaar gaan, s a ngka - meenen, seka - afvegen, s oka zekere bloem, tjarangka - mand, wara ngka - scheede, sa rang ka - scheede, pusaka - erfstuk, sas a ka - idem, ook: desabestuurder, b a la k a - ten eenenmale.

Er komt uit deze woorden geen beteekenis van $\mathrm{k}$ a naar voren, evenmin blijkt dat de syllaben $\mathrm{ka}$ in de verschillende woorden iets met elkaar te maken hebben.

Van een wortel kan men in zoo'n geval bezwaarlijk spreken. Toch komt het mij voor dat na diepergaand onderzoek ook deze woorden groepsgewijze onder denzelfden noemer - om het zoo eens uit te drukken - te brengen zouden zijn. De moeilijkheid is dat de beteekenis van open wortels moeilijk te vatten is omdat de sprekende slotconsonant ontbreekt. $\mathrm{Zij}$ is vaag en door divergeering van beteekenissen verder vervaagd. Met dat al zijn er ook grondwoorden waarin geen wortel aanwezig is. In het vervolg beperk ik den naam ,wortel” tot die welke als zoodanig zijn onderkend.

Onder de wortels zijn er die ook zelfstandig voorkomen, 't duidelijkst spreekt dit in de Soendasche umpak basa, haar beteekenis is uit de werkwoorden waarmee zij, zijde aan zijde, gebruikt wordt te bepalen. Wanneer men bijvoorbeeld vindt dat de wortel be k gebruikt wordt in combinatie met - ik geef de vormen zooals zij zijn aangetroffen - digitik - geslagen (met een riet, een roede e.d.), digěbug - geslagen (met een stok, een roede), ma e ha n - dooden, nönggölan - slaan, ragrag - vallen, nuwar - vellen, dipě dang - met een zwaard geslagen, dikadek - heeft een houw gekregen, ditampiling - kreeg een oorvijg, nangkarak - stortte neder, op den rug, ditumbuk - gestompt, gestooten, dan is het duidelijk dat in běk de beteekenis van het neerkomen van een slag, het aankomen van een stoot, het doen van een plof, ligt, maar tevens dat de u. b. alias een wortel, een vager, minder scherp omlijnd begrip dan elk der woorden waar zij bijstaat, vertegenwoordigt, nog vermeerderd door de omstandigheid dat de wortel ongeleed blijft - daarvoor is hij wortel - en dus bij verschillende afgeleide werkwoorden, bij transitieve en intransitieve begrippen dienst doet. De verschillen kunnen aanzienlijk zijn. 't Is daarom niet uitgesloten dat een gelijk- 
luidende maar overigens ondoorzichtige tweede syllabe van eenige woorden toch tot een beteekenis die alle woorden omvat teruggaat en oorspronkelijk een echte wortel in den bovenomschreven beperkten zin is geweest.

Voorts is ter bepaling der beteekenis van wortels van belang dat wanneer verschillende klinkers tusschen dezelfde consonanten zijn ingeklemd, de wortels in beteekenis verwant kunnen zijn en bijgevolg ook de daarvan afgeleide grondwoorden. Ik geef hier de nevenvormen van het reeds genoemde b ěk en moge overigens naar het artikel: De Soendasche umpak basa, in deel 102 dezer Bijdragen verwijzen.

wortel bĕk: bĕběk - stampen, a mbĕk - woede, woedend;

wortel bak: tĕ bak - met kracht aankomen tegen; b a bak - open, ontveld, v. huid; b a ba ka n - nieuwe nederzetting, d.w.z. een plaats die door kaalslag oirbaar is gemaakt; tumbak - lans; kěbak plassen; kobak - spel met kamirinoten enz., die in een kuiltje moeten worden geworpen; $1 \mathrm{ambak}$ - baar; o mbak - golf; r o mbak opruimen, b.v. een aanplant in een tuin, misschien ook: $\mathrm{tambak}-$ waterkeering;

wortel bik: ĕmbik - stooten;

wortel buk: bubuk - gruis, molm; babuk - in het wilde houwen; t ěbuk - omstooten; t u mbuk - stompen;

wortel bok: bo bok - een gat maken ergens in, doorslaan; t ĕ bok - iets steviger maken door er iets tegenaan te doen; te mbok - metselen; t ja bok - kaakslag.

Deze woorden zijn aan het Soendaasch ontleend, soortgelijke reeksen kan men ook voor andere talen opstellen.

Omtrent de waardij van de slotconsonant voor de beteekenis van den wortel geldt m.m. hetzelfde als vroeger omtrent de umpak basa werd opgemerkt. Hiernaar moge kortheidshalve worden verwezen.

Andere éénlettergrepige woorden zijn o.a. nadrukwijzers, uitroepen, voornaamwoorden, bijwoorden. $\mathrm{Zij}$ laten zich het best met wortels vergelijken en treden inderdaad wel als zoodanig op, d.w.z. dat er grondwoorden van gevormd worden op dezelfde wijze als met andere wortels geschiedt.

De bovengegeven definitie van een grondwoord verdient dus aanvulling. 't Kan immers zijn dat het een wortel bevat die als zelfstandig woord in gebruik is, met name geldt dat voor de umpak basa, in dat geval is een grondwoord nog nader te ontleden. 
Op drieërlei wijze zijn grondwoorden van wortels afgeleid:

L. Door affigeering.

II. Door herhaling en reduplicatie.

III. Door vóórvoeging eener willekeurige, open syllabe.

Van één wortel kan meer dan één wijze van afleiding bestaan.

Hiermede wil niet gezegd zijn dat de taal eenmaal uitsluitend uit wortels zou hebben bestaan en grondwoorden eerst in een later stadium zijn gevormd. Een taal die zich van affixen bedient, spreekt niet in wortels. Verder kunnen wij niet teruggaan.

\section{Affigeering.}

Een aantal affixen welke thans nog als formatieven bij grondwoorden in gebruik zijn, komen ook in verbinding met wortels voor, deze afleidingen zijn ten deele als zoodanig in gebruik, ten deele zijn zij alleen grondwoord in engeren zin, d.w.z. dat zij een nader formatief behoeven. Er is tusschen afleidingen van grondwoorden, zelf uit een affix + wortel bestaande, eenerzijds en wortels met affixen anderzijds in wezen geen verschil, slechts zijn de eersten afleidingen in de tweede macht.

Als formatieven van wortels komen voor-, in- en achtervoegsels voor, van dezen zullen thans eenige voorbeelden gegeven worden.

\section{a. Prefixen.}

$\mathrm{ma}-, \mathrm{a}-, \mathrm{ma}^{\mathrm{ns}}, \mathrm{a}^{\mathrm{ns}}$. In verbinding met grondwoorden gebruikt zijn $\mathrm{ma}-$ en a-, $\mathrm{ma}^{\mathrm{ng}}$ en $\mathrm{a}^{\mathrm{ng}}$ gelijkwaardig, tusschen enkel prefix en prefix met nasaal wordt onderscheid gemaakt. $\mathrm{Ma}$-, a - kunnen possessieve beteekenis hebben, b.v. Oud-Jav. mahayu $=$ ahay u schoon,' goed, van h a y - het schoon, goedheid; 't zelfde vindt men in Mak. en Boeg., Bataksch, de Filippijnsche talen, Samoa, Malagasi enz. $\mathrm{M} \mathrm{a}^{\mathrm{ng}}, \mathrm{a}^{\mathrm{ng}}$ - drukken een handeling uit. Dezelfde prefixen komen tesamen met wortels voor, de juist genoemde onderscheiding geldt voor de wortelafleidingen echter niet, $\mathrm{m} \mathrm{a}^{\mathrm{ng}}-, \mathrm{a}^{\mathrm{ng}}$ - kunnen possessieve beteekenis hebben, omgekeerd kunnen $\mathrm{ma-}$, a - afleidingen actieve werkwoordsvormen zijn; de prenasateering (nasaleering) heeft hier een andere beteekenis.

Van den Javaanschen wortel tut, nog als zelfstandig woord in gebruik: volgende, langs, tut buri - achteropvolgen, is afgeleid ma nut, a nut - volgen; van $1 \mathrm{ih}$, bijvorm van $1 \mathrm{i}$ - ander (V. G. V 50), komt malih en alih * veranderen, in plaats van alih zegt 
men ook ngalih (Wb. s.v. $1 \mathrm{ih}$ ), het eerste staat tot het tweede als een wortelactief tot een door prenasaleering opnieuw actief gemaakt, als grondwoord beschouwd a lih.

Het Soendaasch bezit vele werkwoorden welker actieve vorm uit a + wortel bestaat zooals a bus - binnengaan, a prok $=$ a mprok samentreffen, de wortel prok is u.b. bij werkwoorden die ,elkaar ontmoeten, op elkaar stooten" beteekenen. Doch men vindt ook dat zij als gw. worden opgevat en door prenasaleering geactiveerd worden, bv. $\mathrm{ngabrul} \mathrm{-} \mathrm{in} \mathrm{menigte} \mathrm{aankomen,} \mathrm{nooit} \mathrm{abrul,} \mathrm{van} \mathrm{den} \mathrm{wortel}$ b r ul, u.b. bij werkwoorden die een komen of gaan uitdrukken, steeds van velen gezegd, nga rot - drinken, a r ot komt niet voor, rot is u.b. van „drinken”. A pung van wortel pung waarin de beteekenis „omhoog, de lucht in gaan" ligt, bv. v. e. pijl; v. vliegen gezegd, luidt als predicaatswoord ngapung maar men zegt manuk apung de leeuwerik, enz.

De Filippijnsche talen en talen van Selebes bezitten, afgezien van nadere toevoegingen, twee passieve vormen van het werkwoord, nl. het grondwoord zonder meer en het grondwoord voorafgegaan door p a -, de laatste geldt als duratief, zie bv. Adriani, Tontemboansche spraakkunst blz. 85 (vgl. deze Bijdragen dl. 99 blz. 299), doch het onderscheid wordt niet in het oog gehouden. Dit passief is gelijk aan ons verl. deelw., wat meebrengt dat het verbaal en nominaal gebruikt wordt. Tegenover dit verbreed passief staat de actieve vorm met $\mathrm{ma}$-, deze is dus aan de passieve gecoördineerd en niet gesubordineerd, want men vindt thans nooit $\mathrm{mapa}^{-1}$ ). In Jav., Soend., Mal. is het passief altijd gelijk aan het grondwoord, de verbreede vorm komt in deze talen bij het grondwoord niet voor. In het Soendaasch is het zeer gebruikelijk als verl. deelw. zoowel verbaal als nominaal, in het Javaansch minder, in het Maleisch in het geheel niet, daar is het woord alleen grondwoord en men kan hier dus zeggen dat het actief aan het passief gesubordineerd is ( $\mathrm{tulis}, \mathrm{manulis}$ ). In het OudJavaansch vindt men oud en nieuw naast elkaar: a n paçilā - op den grond gaande zitten (in sila - houding), gesubordineerd, passief verbreed, $=$ ma çilā, gecoördineerd ${ }^{2}$ ). Bij wortelactieven is van dit alles geen sprak, zij zijn rechtstreeks van den wortel gevormd. O.-Jav. $\mathrm{man} \mathrm{j}$ a l, penis is dus rechtstreeks van $\mathrm{t} \mathrm{j}$ l, juister van $\mathrm{n} \mathrm{j}$ a 1 (zie hiervoor hoofdstuk V), doch Jav. mantjal - met de voeten

1) Het causatieve $p a$-, dat een ander prefix is, blijft buiten beschouwing.

2) H. Kern, Kawi-studiën blz. 53, - 's-Gravenhage 1871. 
zich opgeven en met een sprong opstijgen, Soend. ma n t j a 1 - stijgen op, springen op, beiden uit *m a mant j a l, van gw. pa n t j a l, is gesubordineerd. De beteekenis „stijgen op, springen op" is een voortzetting van de eigenlijke beteekenis ,het loskomen van iets", want t j a 1 is ,van iets losgeraakt, - gemaakt”, cf Jav. but j a 1 - wegwerpen, it ja l. verdwenen, weg en vgl. den verwanten wortel tjul. $\mathrm{Pa}$ - + wortel komt in Mal., Jav., Soend. in de beteekenis van een verl. deelw. wel voor, bv. Jav. p a ḍ̆ m, Soend. pa rö m, Mal. pa d a m - uitgebluscht, cf. Jav. ĕ ṇ ḍ̆ $\mathrm{m}$ - verborgen, geheim gehouden, Soend. pöröm - met de oogen gesloten; Jav. padjĕg - vaste belasting (niet een evenredig deel), lett. het vastgestelde, het rechtop staande. - Verdere voorbeelden van $\mathrm{ma}$-actieven van wortels: mabuk, Mal., Bat., dronken, Bat: Kar. ook ,woedend”, Jav. mabuk, mabok - dronken, woedend, Day, mabok - heftig, is $\mathrm{ma}+\mathrm{buk}$, in welken wortel ,woedend aanvallen, in het wilde slaan" ligt. - M a suk, Mal. binnengaan, Bat. idem, Day. $\mathrm{m}$ a s o k - binnengaan, behooren tot, Jav. mas uk, masup - binnengaan, Soend. a sup - binnengaan, behooren tot, Mgd. mas ok, doch Tag. pasok gw. waarvan mag pasok - binnengaan. Doch Bat. Tob. en Mand. dat ma - niet als Jav. en Soend. laat vallen en Soend. a s u p wijzen erop dat $\mathrm{masuk}$ bestaat uit $\mathrm{ma}-+\mathrm{suk}$, in welken wortel de beteekenis ,ergens ingaan” ligt, evenals in s u p, cf Jav. ngěsuk - iemand tot in zijn schuilplaats vervolgen, gw. ĕ s u k Soend. $\mathrm{nj}$ u s u p - ergens in kruipen, gw. s u s u p. - M a sa k Mal. gaar (intrans.), koken (trans.), Soend. a s a k - gaar, Bat. m a s a k - gaar, rijp, droog, waarvan ma r ma sa k (Mand.) - koken, het Bat. heeft dus ma sak als gw. opgevat. - M ang k is, Day. juichen, wortel ki s, gezegd van gedreun bij niesen. - M a p ok I Day. - in de handen klappen, in den wortel pok en nevenvormen ligt de beteekenis -,slaan”, Soend. pu k, k ěpu k, tĕ p u k - slaan, bv. naar een vlieg, Jav. k ěplok - met versterkten wortel, in de handen klappen, gěpuk beuken, een slag geven; mapok II Day. - bloeien, van een anderen wortel p o k - met velen bijeen, Soend. $1 \mathrm{u} \mathrm{m} \mathrm{p} \mathrm{u} \mathrm{k} \mathrm{-} \mathrm{op} \mathrm{een} \mathrm{hoop,} \mathrm{Soend.}$ Jav. t umpuk - stapel, verwant is pěk, Jav. Soend. pĕpěk - allen bijeen. - M a nd j on g Day. - de zielen der rijst naar de sa ng i a ng (luchtgoden) zenden, doch mandjung Bat. Mand. - vooruitstekend stuk grond in de bocht van een rivier, landtong, cf. $\mathrm{d} \mathrm{j} \mathrm{u} \mathrm{n} \mathrm{g} \mathrm{-}$ d j ung - staak of stok waarlangs men een plant omhoog laat klimmen, Soend. d j ung, u.b. van ,opheffen, oprijzen”. Van verwanten wortel Soend. bodjong, ook bobodjong $=$ Bat. mandjung. 
- De Jav. wortel țik, met nevenvoren țak, țuk, țĕk, țok, ook in andere talen verbreid, beteekent ,tikken, kloppen”. De verbreede, passieve vorm komt bv. voor in het Boeg. p a ti' ${ }^{1}$ ), thans gw., lett. getikt, geklopt. De actieve werkwoordsvorm hiervan luidt ma 'pati' tatoueeren. Het Tont. gw. luidt patitj, waarvan mapatitj schrijven, doch hiernaast is matitj in gebruik, rechtstreeks van den wortel gevormd. Mal. pantik, alleen gw., beteekent ,,met iets hards tegen iets slaan of wrijven', de laatste beteekenis is oneigenlijk.

't Is bekend dat de ma-vormen ook de beteekenis van een substantief kunnen hebben, ik behoef slechts te herinneren aan de vele met $\mathrm{ma}$ - beginnende namen van boomen en andere planten, welke in schier alle Indonesische talen voorkomen. 't Zelfde geldt van ma afleidingen van wortels. Voorbeelden:

manuk Austron. - vogel, hoen (Fidji manu-manu - gevogelte). Wortel is t uk, aanwezig in Soend. pat uk - pikken ${ }^{2}$ ), pa mat uk - snavel, man u k beteekent dus ,de pikker”. van der Tuuk is van meening dat het woord oorspronkelijk het hoen aanduidt en de beteekenis ,,vogel” secundair is. Uit de benaming valt dit niet op te maken, daar zij op alle vogels toepasselijk is. Doch in aanmerking genomen dat in een groot aantal talen het woord ,hoen” beteekent, in de tweede plaats dat de naam verhullend is en ten derde dat het hoen een belangrijke plaats in het religieuze, ceremonieele leven der Indonesiërs inneemt, lijkt zijn veronderstelling juist. - Day. ma n d a u - zwaard, Bahnar, Stieng d a o - sabel, ik vermoed dat de wortel eigenlijk , ,vlijm” of iets dergelijks beteekent. - M a ng kuk Mal. kom, kopje, Bat. kopje, Jav. kom, Day. ma n g k o k, Boeg. ma n g k o' kom, Gaj. man g k u n g - ronde kom van aardewerk waarin eetwaren, toespijzen bij de rijst enz. worden meegedragen. In de wortels $\mathrm{kok}$, kuk en de nevenvormen kong, kung ligt de beteekenis ,krom, gebogen", cf. Mal., Jav. be n g kok - krom, Bat. beng kuk, bengk ok, Day. be n g k ok, bi n g kok idem, Mal., Jav. bung k u k - gebocheld, gekromd, Mal. 1ĕng kung - gebogen, gewelfd, d j ong k ong - bootje v. e. uitgeholden boomstam; Jav. b ĕng ku k - krom, leng kongan - bocht, inham, bĕngkung, Bat. Mand. bongkung krom, Toba beugel, Day. buk ong - pot met sterk omgebogen rand. De beteekenis van mangkok is dus ,kromte hebbende, iets wat krom, gebogen is, naar den vorm van het kopje. - Mal., Jav. m ĕn t a h, Bat.

1) Wb. s.v. $2^{\circ}$ pati, onjuist gespeld. Het woord luidt ten rechte pati, cf. apatikěng - tatoueering.

2) Mal. patuk is gw. van pikken, bijten, v. slangen. 
t a t a, mata, Day. m a n ta, Boeg. Mak. ma'ta, Soend. a ta h - rauw, ongekookt, onrijp. Wortel is tah, in het Jav. heeft deze het accent behouden en is de a van het prefix tot ě verzwakt. Gewoonlijk verspringt de klemtoon naar analogie van tweelettergrepige woorden, zoo altijd in het Soendaasch, ook Boeg. ma't a heeft het accent op de eerste lettergreep, doch $\mathrm{m}$ a $\mathrm{n} \mathrm{r}$ - ginder, van het demonstratief $\mathrm{ra}$, dat niet afzonderlijk voorkomt, doch een nevenvorm ro heeft, bv. i y a - r o - die daar, heeft het accent op het hoofdwoord. In de Filippijnsche talen heeft $\mathrm{m}$ a n úk - hoen (zie boven) den klemtoon op het hoofdwoord behouden. - Oud-Jav. a bāng, ma bāng - rood, Gaj. $\mathrm{ma} \mathrm{mbang}$.

Prefix mar-, mara-. Dit prefix komt ook in verbinding met wortels voor, bv. Jav. mă rgag - aarzelen, niet verder durven, in den wortel g a g ligt de beteekenis ,,stoppen, tot stilstand komen”, vgl. g o g beneden, blz. 286, bv. Soend. a g a g - de hand opheffen om te slaan, den voet om te schoppen, doch niet doorzettend, pugag onderbroken, niet tot stand komen, Jav. afgesneden, zonder top; mă rgil - zich afscheiden, afgezonderd P., de beteekenis van den wortel gil is ,er af, ergens van af gedaan”, Soend. rigil - afgevreten, als bladeren aan een boom door rupsen. Verwant is $\mathrm{g}$ ĕ 1 , u.b. bij potong - gebroken, ditug ěl - afgeslagen, Jav. dwars gebroken, gehakt enz.; Soend. ma ra p i t - van weerskanten insluiten, de wortel pit beteekent ,drukken, knijpen”, Jav. idem, nauw aaneengesloten.

Het prefix pa - kan den persoon aanwijzen die zich met het in het grondwoord uitgedrukte bezig houdt, bv. Soend. p a k ěbo n, pa $\mathrm{ng}$ ĕbon - tuinder, p a n j a w a h - boerenarbeider voor de sawah. Er zijn enkele voorbeelden dat pa - tesamen met een wortel aldus gebruikt wordt, bv. Jav. pa muk - voorvechter, van $\mathrm{muk}$, den genasaleerden vorm van den wortel b u k, zie beneden blz. 353, (De genasaleerde wortels worden in het volgend hoofdstuk behandeld); Jav. pamong - verzorger, mong is weer de genasaleerde vorm van wong, cf. winongwong = dimongmong - beschermd, Wb. s.v. wong - mensch, het woord heeft echter met wong - mensch niets te maken; Mal. pa w a n g - deskundige in zaken van landbouw, geneeskunde, jacht, werkende met magische middelen, Bat. Mand. iemand die bedreven is in de kunst honing te halen, iemand die de kunst verstaat krokodillen te vangen, de beteekenis van den wortel is onzeker, misschien te vergelijken met Jav. wangwang, wawang - het 
aanzien bij het aanschouwen, de beteekenis zou dan zijn ,schouwer, ziener".

Verbaal substantief met $\mathrm{pa}^{\text {ng }}$ of $\mathrm{pa-}$, van wortels afgeleid: Jav. parigan - voedsel, wortel kan; Jav. pangreh - bestuur, O.-Jav. reh - orde van zaken; panglong, in den wortel long ligt de beteekenis ,afnemen, verminderen”, het woord zou als substantief ,het afnemen, afneming" beteekenen, doch is als adjectief in gebruik: w u la n pang long - afnemende maan. - Bat. Mand. pantik - een houw, nl. zooveel als men met eenmaal te slaan kan afhouwen (een houwing). - Met instrumentale beteekenis : Jav., Soend. pa n g ot schrijfstift, wortel kot, de beteekenis wordt duidelijk uit Soend. korokot - krabben; Jav. pan on - het gezicht, maar Soend. instrumentaal, oog, datgene waarmee men ziet naar een schouwspel, wortel ton, cf. tonton, Soend. tongton. - Jav., Soend. par ud - rasp, in den wortel $\mathrm{r}$ ud ligt de beteekenis „schrapen, wegvagen”. Bat. pangkur - hak, Jett. waarmee men den grond omwerkt, cf. Jav. kuku r - krabben, Mal. id. - krabber, Soend. id., raspen, Mal. s ungkur - omwroeten, Soend. id. - den grond omwerken, Mal. pangkur - houweel bij het winnen van sago gebruikt (sagokrabber), cf. Jav. patjul, zelfde beteekenis als Bat. pangkur, van t j u 1 - los, losgemaakt v. iets anders.

Prefix ba-, ba r-, bar a -. In het Javaansch thans een dood prefix maar in een aantal, nu als gw. opgevatte woorden bewaard. In het Soendaasch is de toestand zeer eigenaardig. Het prefix leeft nog in uitdrukkingen die een hoeveelheid aangeven: ba rebu-rebu - bij duizenden, en is in dit geval synoniem met $\mathrm{mang}-$, doch als verbaalprefix is het dood, in badami - beraadslagen, vormelijk = Mal. bĕrda ma i, wordt het prefix niet meer gevoeld $^{1}$ ). Deze afleiding kan ook nomen zijn.

't Zelfde geldt van ba - afleidingen van wortels, ook in het Maleisch, hoewel daar b ĕ $\mathrm{r}$ - tot de levende prefixen behoort. Voorbeelden: Jav. ba but - uittrekken, in den wortel ligt dezelfde beteekenis ,uittrekken, aan iets trekken" : r a b u t - uittrekken, lichten; de grondbeteekenis van r ĕbut is ook ,wegtrekken (om strijd)", nog verder verloopen in s a mbut - ter hand nemen, leenen. - Jav. bang $\mathrm{krung}$ - krom, krung is versterkte vorm van kung, zie boven blz. 282. - Jav. bant jang - vastbinden, de beteekenis van den wortel is "gebonden, strak", cf. tj a ntjang - vastgebonden. - Jav.

1) Gewestelijk is het prefix nog levend. 
b a r ěp - de eerste, voornaamste, lett. de vóór-zijnde, r ěp is „vóór”. - Jav. bĕr s ot $\mathrm{P}$ - zich uit de voeten maken, s o $t=t \mathrm{j} \mathrm{ul}$, Wb. s.v. - los, boven blz. 281, vgl. Soend. s ot u.b. vóór: le s ot - los, p o ho vergeten. Het $\mathrm{Wb}$. geeft de spelling brěsot, een gewijzigde uitspraak, ba rěs od s.v., met d als sluiter is foutief, zooals het Soendaasch uitwijst. - Niet geheel zeker is Jav. bĕr d jog - overhaast, overvallen P., het Wb. heeft blĕdjog, wat kan staan voor br ĕdjog, omzetting van běrdjog, doch vermeldt ook balědjog, wat balě- voor bar ĕ- $+\mathrm{djog}$ maar ook versterkte vorm van b ě d j og kan zijn. - O.-Jav. ba r pět - ophouden, verdwijnen, uitdooven, Soend. pět u.b. vóór : afsnijden, afbreken, ophouden, droog komen te liggen.

Soendaasch babuk - in het wilde erop in houwen, wortel buk slaan met kracht - badug - met den kop of de hoorns zijwaarts stooten, wortel dug is u.b. o.a. van het stooten met de hoorns v. e. buffel - band ju r - overgíeten, in den wortel d jur ligt de beteekenis ,,vloeien, al maar doorgaan, den vrijen loop laten (boven blz. 276), a d j u r - gesmolten, vloeiend, vergruisd; $1 \mathrm{adjur}$ - an iets den vrijen loop laten, $\mathrm{djudj} \mathrm{u} \mathrm{r} \mathrm{-} \mathrm{anhoudend} \mathrm{in} \mathrm{dezelfde} \mathrm{richting} \mathrm{gaan.}$ - ba ntjul - schieten met moentjangnoten (spel), wortel tjul b a t i k (aldus, zonder verder voorvoegsel) - batikken. - b a r a n j a j - glinsteren, flikkeren, $\mathrm{njaj}$, u.b. vóór: pikiran t ja ang sa ötik - daar ging hem een licht op. - baradal - uit elkander (gaan, doen), in den wortel d a 1 ligt de beteekenis ,,uit zijn verband geraakt", b.v., met klankverwisseling, b u ra d u 1 - uit elkaar gerukt (Wb. s.v. a m buradul, met oud a-prefix (boven blz. 280), buda 1 - v. velen, naar buiten gaan, (als kinderen uit een school), s ĕn da 1 - ontrukken, Jav. ḍ a ḍ a 1 - weggespoeld, weggeslagen, weggevaagd. - Mal. bĕrkas - bos, schoof, bundel, eig. een bos uitmakende, maar als gw. opgevat, waarvan mĕmbĕrkas - bosselen, Jav, bĕ rkas - bundel, pak; in $\mathrm{kas}$ en de variant $\mathrm{kus}$ (er is meer dan één wortel $\mathrm{kus}$ ) ligt de beteekenis ,inwikkelen, iets ergens indoen”, $1 \mathrm{ik}$ a s - haspelen, b u ng k us - inpakken, Soend. te n g kas - iemand den voet of de handen om de beenen slaan en die naar zich toe trachten te trekken.

Een voorbeeld uit het Bataksch is Kar. běrkat - opbreken, = prefix bĕr - (ba r -, thans door ĕ r -, uit ha r -, verdrongen) + wortel kat waarin de beteekenis ,oprijzen, opheffen”, van iets op- of afgaande, ligt, cf. Mal. Jav. ang kat enz.

Boeg. bampa' - hard, stevig kloppen, de wortel pa' (pak) beteekent ,slaan” (boven blz. 281). 
Prefix ta-, tar-, tara. Javaansch en Soendaasch hebben lang geleden dit prefix bezeten, in het Oud-Javaansch is het reeds niet meer levend, het Soendaasch bezit nog den nevenvorm $\mathrm{t} i$ - in accidenteele beteekenis: titadjong - ergens met den voet bij ongeluk tegenaan stooten, het passieve karakter is verloren. De woorden waarin t a - bewaard is, zijn vaak niet meer passief of nomen, b.v. Oud-Jav. ta rawang - doorboord (waarvan a narawang - doorzichtig, man a rawang - duidelijk (het woord was dus reeds in het Oud-Javaansch (secundair) grondwoord geworden), vgl. k a r a w a n g - gescheurd muziekbekken, Soend. k a r a n t j a n g - vol gaten. - Jav. t a la ngke - geduldig afwachtend, zonder haast te maken, Soend. dralen, talmen, Mak. 1angke waarvan a 'langke - blijven vastzitten, Jav. ta la k up - schutblad, Soend. ta la k op - bamboeschutblad, 1 a k op - klemlat, klamp. In Mak. en Boeg. vindt men m. $\mathrm{m}$. hetzelfde: Mak. angka' - oplichten, tarangka' - opbreken, vertrekken, Boeg. akka', ta rakka'.

De verbinding $\mathrm{ta}$ - met een wortel geeft hetzelfde te zien: Jav. $\mathrm{t} \mathrm{a}$ b ĕt - achtergelaten spoor, de wortel b ět beteekent, ,een spoor vormen, door trekken of slaan", s a b ět - een zwiependen slag krijgen, gras wegslaan, Jav., Soend. 1 a b ĕ t - achtergelaten spoor, met variant : Soend. butbat, van wegen die zich in allerlei richtingen door het land uitstrekken. - Jav. t ěmbu s - doorloopende ergens uitkomen, bus heeft het accent behouden, vandaar klankverzwakking in het prefix, door en door, cf. Soend. bu s, u.b. van ,ingaan, binnengaan”, bubus (Wb. s.v. mubus) - ergens ingaan om er een toevlucht te zoeken, $1 \mathrm{a} \mathrm{m} \mathrm{b} \mathrm{u} \mathrm{s} \mathrm{-} \mathrm{blaasbalg.} \mathrm{In} \mathrm{het} \mathrm{Javaansch} \mathrm{is} \mathrm{de} \mathrm{beteekenis} \mathrm{,er-}$ gens ingaan tot men er weer uitkomt”, vandaar: $\mathrm{d} \mathrm{j}$ ĕb u s - daar iets op uitloopt, uit een opening te voorschijn komen. - Jav. t a n g k ěp op elkaar passend paar, wortel kĕp, varieteit van ku p - vast aaneen; t a s a k - rijp, vgl. ma sak, boven blz. 281. - Jav. (pating) těrtjĕb - (overal) geprikt, prikkeling, Soend. t j ě b, u.b. van ,ergens insteken”, $\mathrm{t}$ a $\mathrm{n} \mathrm{j}$ e b - indringen, Jav. idem, het in den bodem stekende gedeelte van iets. - Soend. ta g o g - op de hurken gaan zitten, in g og ligt de beteekenis ,stoppen, tot stilstand komen”, u.b. vóór: tjang o go - op de hurken gaan zitten, těpung - op iemand stuiten, ta g o g kön - zet neer! stop ermee! t u ga g - ta g o g - telkens blijven staan, panag ogan - roestplaats y. hoenders, plaats waar een koopman met draagbare waar zich opstelt, tagog ook poststation ${ }^{1}$ ). - Andere voorbeelden zijn nog: Jav. ta m bah - iets

1) Het $\mathrm{Wb}$. moet met een en ander worden aangevuld. 
erbij, wortel wah - idem - Jav. ta p ěl - beslag (op een kist), gw. dichtsmeren, Soend. kleven, pěl is u.b. vóór : ta p ěl, r a p ĕt - aaneengesloten, mölit - zich om iets strengelen, te mpel - vastgeplakt, du m pěl - dichtmaken, kĕmpĕl - dicht opeen, enz. - Jav. tĕr $\mathrm{d}$ j a n g, Soend. t a r a d j a n g - Jav. krachtig aanvallen, Soend. id., op iets aankomen, treffen, in den wortel $\mathrm{d} j \mathrm{j}$ ang ligt de beteekenis ,ergens op afgaan", Jav., Soend. rundjang - op iets losstormen, Soend. rondjang - opspringen bij (zooals een hond doet), misschien is ook Soend. radjang - een soort mes of sabel, inz. door vrouwen gebruikt, hiertoe te rekenen. 't Aantal van wortels afgeleide $\mathrm{ta}$ - vormen is vrij anzienlijk.

In het Maleisch is t ĕr - levend prefix, niettemin zijn de $t$ ĕr - afleidingen van wortels actief, bv. tĕ r bang - vliegen, stuiven, b ĕng is Soend. u.b. van woorden die een zich snel verwijderen van een punt uitdrukken, als het afschieten van een pijl, hard wegloopen, e.d. - ter r bit - te voorschijn komen, bit $=$ Jav. wit - oorsprong, kiem, begin. - tĕrdjun - afspringen van iets; $d j u n$ dunkt mij een variant van $\mathrm{djut}$, 't komt nl. meer voor dat tenuis en homonyme nasaal als slotconsonant wisselen, zie boven $k \breve{p}$ en $k e \check{m}$; $d j u t$ is Soend. u.b. van t u r u n - dalen, naar beneden gaan (uit een huis b.v.). Ook t a - komt voor, ongetwijfeld een oudere vorm, bv. t a n g k u p vast tegen elkaar gesloten, in den wortel ligt de beteekenis „omvatten, bedekken, nauw aangesloten".

In het Tontemboan is $\mathrm{ta}$ in veelvuldig gebruik, een voorbeeld van een afleiding rechtstreeks van den wortel is t a $\mathrm{g} \mathrm{k} \mathrm{u} \mathrm{p} \mathrm{-} \mathrm{het} \mathrm{schelp-}$ achtige omhulsel dat onder aan de vrucht van sommige vruchten zit, van wortel kup, hiermee is te vergelijken Soend. talakop, Jav. t a la kup, afgeleid van een gw. la k op ( $\mathrm{akup}$ ), boven vermeld. -

$\mathrm{ta}$ ' $\mathrm{mbe}$ - moeras, bevloeid rijstveld, is van een verloren gegaan $*_{\mathrm{w}} \mathrm{e}$ - water. Merkwaardig is t a k u l - leven of geraas waardoor het wild wordt weggejaagd, de wortel kul of kol beteekent ,slaan op iets zóó dat geraas voortgebracht wordt: Jav., Bal. kulkul, Soend. kohkol - seinblok; Tont. tangkar is ,los, vrijgekomen van zijn omhulsels", denzelfden wortel vindt men terug in Jav., Soend., Mal. bo ngkar - open, losbreken. Tangkal is ,tikken of kloppen op den rand v. iets, om het losser te maken van zijn omgeving", t e n $\mathrm{g}$ kor (volgens het Register te ngkol) is ",slaan op een gong of iets anders met een stok of stuk hout"; $r$ en $l$ wisselen in Tont., door contaminatie van tangkar heeft tangkal de door de onderstreepte woorden aangegeven, gespecialiseerde beteekenis gekregen, 
t engkor staat voor *tengkol. De oorspronkelijke beteekenis van takul moet geweest zijn ,slaan ergens op om geraas te maken"; geschiedt dit met de bedoeling wild gedierte te verjagen, dan geraakt men tot de tegenwoordige beteekenis. Men weet nu meteen aan welke wijze van verjagen oorspronkelijk gedacht moet worden. Men kan thans de jongens op het land in Java nog wel bezig zien met kleine seinblokjes om vogels of andere dieren te verjagen.

Voorbeelden van $\mathrm{ta}$ - in verbinding met een wortel in het Tagalog: t a pos - einde, in den wortel ligt de beteekenis „op, ten einde”, vgl. Mal. pupus - geheel op, v. geld of goed, afgestorven, v. planten, Soend. p u p u s l.p. - gestorven. - ta s u k - prop, pin, de wortel s u k beteekent ,ergens ingaan”, cf. ma s u k - binnengaan enz. - taki p, Bis. t a k o p- deksel, bedekking, de wortel kěp houdt in: grijpen, omsluiten, vast aaneen.

Het Dajaksch bezit de prefixen t a - en t a r a -, het eerste komt veel voor, zij zijn niet meer levend, het aantal met $\mathrm{ta}$ - samengestelde grondwoorden is zeer groot. Er zijn ook afleidingen van wortels. Voorbeelden van g.w.n: tabuni - nageboorte, tarabagi - gedeeld, ta langkop $=\mathrm{tangkop}$, van wortel kop, komen naast elkaar voor, vgl. boven voor Jav., Soend. en Tont., de beteekenis is „met de openingen op elkaar" ( 2 kopjes), dus een geheel andere dan boven, maar evenzeer uit die van den wortel voortvloeiende.

Van wortels: ta bok - uitgehouwen (boomstam tot kano), in bok en verwanten ligt de beteekenis ,,aankomen tegen, treffen, slaan” (boven blz. 277, 278) cf. Jav. b o b o k - ergens een gat in breken, t e m b o k - metselen enz. - t a t u p - op elkaar, van 2 zaken, zelfde beteekenis in den wortel en varianten: tu tup - gesloten, Jav. a těp - dakbedekking v. alang-alang, Soend. en tep-söröh als sirihbladeren op elkaar gelegd, overdr. keurig in orde, - ta r a tĕ p - gesloten.

Het Bat. Mand. heeft ta-, ta r - en tang-, bv. tagor - een onderaardsch gerommel, vgl. Soend. g o r, g u r, u.b. een zwaar geluid aankondigende, taring ot - ergens een herinnering aan ophalen; men zegt martaringot, dus ta $\mathrm{r}$ - wordt als een deel van het gw. beschouwd, ta n g k u p - grijpen, de wortel kup drukt hetzelfde uit. Het Karo'sch heeft t a - en tan g-, bv. t a sa k - rijp, van den wortel sak met gelijke beteekenis, vgl. Soend. as ak, Mal. masak, ta ng k u p - op elkaar sluiten van twee helften, als de schalen v. e. schaaldier.

Naast ma-, ba-, t a-, die men de standaard prefixen zou kunnen 
unemen, staan nevenvormen met anderen klinker, ten deele nog hier en daar in gebruik, voor een ander deel alleen nog in secundaire grondwoorden aan te wijzen; in het laatste geval is de formatieve kracht moeilijk te bepalen, temeer als de beteekenis van het eigenlijke grondwoord onbekend is. Verder is het vaak niet uit te maken of men met een (verloren) zelfstandig prefix te doen heeft dan wel met een onvaste of gewijzigde uitspraak. Zoo schijnt bv. Soend. bo - in bolen a ng - kaal, glad, lenang - schoon, zonder vuilnis enz., niet te onderscheiden van ba-; ook in Soend. bohowang - hinniken, gw. howang, waarvan ngahowang - idem, is bo- = ba-, bi - in bihari = bahöla - weleer, = ba- (de beteekenis van hari is niet bekend), maar in bilintik - sparen, verzamelen, balantik - makelaar in vee, heeft men een geval van klankverwisseling dat oogenschijnlijk niets met een prefix bi - te maken heeft. Zoo vindt men ook bi-gevolgd door een wortel, bv. bid jil - naar buiten komen; Jav. wid jil toont echter aan dat bi hier geen prefix $=\mathrm{ba}-$ is. Naast $\mathrm{ta}-$ komt een prefix $\mathrm{t} \mathrm{u}-$ voor, bv. Soend. pat ulajah - door elkaar verspreid liggen, katalajah aan zichzelven overgelaten, hier is $\mathrm{tu}=\mathrm{ta}-; \mathrm{tungguluk}=$ $\mathrm{ta} \mathrm{ng} \mathrm{g} \mathrm{u} \mathrm{luk} \mathrm{-} \mathrm{op} \mathrm{een} \mathrm{hoop} \mathrm{liggen,} \mathrm{a} \mathrm{is} \mathrm{in} \mathrm{u}$ overgegaan als gevolg van assimilatie, zoo ook t ung gulung - oprollen, van g u lung opgerold, waarnaast *tang g ulung ontbreekt. Van een beteekenis van $\mathrm{t} u$-, afwijkende van $\mathrm{t} a$, blijkt niets, ja zelfs van een zelfstandig bestaan is geen zekerheid. 't Lijkt daarom geboden zoolang omtrent deze verloren prefixen nog geen klaarheid is verkregen, de vraag of zij tesamen met wortels optreden, te laten rusten. De mogelijkheid mag men zeer zeker aannemen, mochten er zulke woorden gevonden worden, dan zouden zij het boven betoogde slechts versterken.

De eenige duidelijke nevenvorm welke in het Soendaasch nog bestaat is t i -, t a - is sedert lang verloren. De beteekenis (bij grondwoorden) is uitsluitend accidenteel, daarbij actief, de agens verricht de handeling ongewild. Dit prefix komt met wortels voor, bv. tig a s - afgesneden, afgedaan, de wortel beteekent ,,er af, afgescheiden" bv. 1 a g a s - zonder echtgenoot(e), lugas - ontbloot, pagas - afslaan; timbul - oprijzen, Mal. aan de oppervlakte komen, de wortel bu 1 is u.b., wordt van het opwolken van wierook gezegd, doch tingkěb wisselt met ta ngkěb, gezegd o.a. v. d. luiken v. e. waroeng, e.a.m.

Het Tagalog heeft een nevenvorm $t i$, gebruikt tot vorming van distributieven, waarvoor andere talen $\mathrm{ta}$ - bezigen, het komt ook in verbinding met wortels voor, er is geen verschil met $\mathrm{ta}$ - op te mer-

D1. 102. 
ken, bv. t i pùn - vergaderd, zelfde wortel in Mal. himpun - vergaderen, verzamelen - t is od - uitgegleden, in den wortel su r ligt de beteekenis ,opschuiven”.

\section{b. Infixen.}

De in de Indonesische talen nog gebruikelijke infixen zijn - u m -, - in - en - a n. De beide eersten zijn bekend genoeg, het laatste komt voor in het Iloko. Deze taal infigeert - an - in het verbaal substantief : panaglako - wijze van handelen. $\mathrm{Nu}$ is het verbaal substantief vormelijk passief, het infix schijnt dan ook niet noodig om het passieve karakter duidelijk te maken. De verwante talen volstaan met het prefix pag -, andere Indonesische talen doen $\mathrm{m} . \mathrm{m}$. hetzelfde, de beteekenis van - an - is hier dus slechts het passief karakter nog eens duidelijk te doen uitkomen. Een dergelijke dubbele uitdrukkingswijze is in de Indonesische talen zeer gewoon, men denke aan het dubbele 1e transitief in het Javaansch met -a n + $-i$, dubbel meervoud enz. Vgl. nog Ilk. ka na pon - vereeniging, maatschappij = kappón (uit *kampón), Tag. kampong, $\mathrm{kamp}$ on - clan, stam, troep, Mal. ka mpung. Alle deze infixen en nog verscheidenen meer komen in verbinding met wortels voor om grondwoorden te vormen. $\mathrm{Zij}$ zijn allen terug te brengen tot $-\mathrm{m}$ en - $\mathrm{n}-$, het eerste vormt actieven, het tweede passieven of, wat hetzelfde is, nomina, want de nominale vorm is ook het passief van het werkwoord.

De Austro-aziatische talen maken eveneens gebruik van infixen tot vorming van grondwoorden. $\mathrm{Zij}$ hebben geen bezwaar tegen een opeenvolging van consonanten, een met $\mathrm{m}$ of $\mathrm{n}$ geinfigeerde wortel kan dus monosyllabisch blijven, het monosyllabische karakter dier talen berust voor een deel hier op. De Austronesische talen daarentegen toonen een afkeer van consonantenopstapeling, het is één der kenmerkende onderscheiden tusschen beide taalfamilies. De opeenvolging van 2 consonanten wordt vermeden door tusschen begin-consonant en volgenden klinker van den wortel vóór de geinfigeerde $m$ of $n$ nog een klinker in te voegen, vaak van dezelfde kleur als de vocaal van den wortel, maar dat behoeft toch niet zoo te zijn. Enkele talen dulden twee aansluitende consonanten, mits de volg-consonant een vloeiletter zij $(\mathrm{r}, 1)$, zoo o.a. het Javaansch, maar de meesten scheiden ook dezen.

Wij zullen eerst voorbeelden geven van infigeering in wortels van de nog bestaande infixen. 


\section{Infix - u m -}

In het Tontemboan wordt van de welbekende partikel $\mathrm{ka}$, waarin de beteekenis ,de handeling is geslaagd" ligt, een vorm kuma gemaakt, thans een partikel, ,reeds” beteekenende. Het wordt alleen bij eeñ Perfectum gebruikt en geeft te kennen dat men herhaalt wat men heeft gezegd of aangetoond (Adriani, Spraakkunst blz. 94). Adriani is van meening dat de vorm $\mathrm{kuma}$ dagteekent uit een tijd toen $-\mathrm{um}$ - nog geen andere functie had dan een woordstam tot een predicaatswoord te maken. Inderdaad is de - u m - vorm een actieve werkwoordsvorm, die echter ook de waarde van een naamwoord hebben kan, 't is hiermee hetzelfde als met den m a - vorm.

Voorbeeldenvan infigeering van - um - in wortels:

Soend. d um u k - wonen, wortel duk; aanwezig, met reduplicatie, in Mal. duduk - zitten, wonen, verblijven ${ }^{1}$ ), vgl. Tag. $1 \mathrm{uklok}$ gaan zitten.

Jav. 1 u mut - mos, groen aanzetsel, eendenkroos, Soend. idem mos, mosachtige uitslag op muren, Mal. idem - mos, kroos, wier, schimmel, Bat. idem - mos, Tag. Bis. idem - idem, ook: vuiligheid, slijk, Day. l u mut en, met niet ongewone wisseling van u en i, limut - mos, slijm, modderachtige substantie op het water, Fidji $1 \mathrm{u}$ m i met gewijzigden klinker, de oude klinker is bewaard in $1 \mathrm{umut}-\mathrm{a}-$ besmeren en i - l u m u -smeersel, (V. G. V. 52), de wortel is l u t, waarvan Jav. Mal. pulut - plantenlijm, B.M. pa j o i pulut - kleefrijst, Ibg. $\mathrm{f} \mathrm{ul} \mathrm{ut} \mathrm{-} \mathrm{klevende} \mathrm{honing.} \mathrm{Dezelfde} \mathrm{afleiding} \mathrm{in} \mathrm{Khmer} \mathrm{le} \mathrm{mu} \mathrm{a} \mathrm{t} \mathrm{-}$ kleverig, glibberig ${ }^{2}$ ).

Soend. $\mathrm{rumöh}$ - beslagen, wortel $\mathrm{röh}$, waarvan met vokaalsplitsing rööh - dampig, dof. - Soend. kumur - slijmerig afzetsel, wortel k u r, waarin de beteekenis ,raspen, afschrapen” ligt, cf. k u k u r - raspen, t j uk u r - scheren.

Jav. $\mathrm{t} \mathrm{jumlĕs} \mathrm{-} \mathrm{heerlijk} \mathrm{frisch,} \mathrm{de} \mathrm{wortel} t \mathrm{j} 1 \mathrm{e} s$ is in dezelfde beteekenis in gebruik, hij is de versterkte vorm van $t \mathrm{j}$ ĕ $\mathrm{s}$ - dadelijk frisch. - Jav. k u m a t - weer een aanval krijgen, v. een of ander, in den wortel k a t ligt de beteekenis „van iets op- of afgaande”, cf. a n g $\mathrm{k}$ a t - optillen, p a n g k a t - rang, Soend. $\mathrm{j}$ ĕ n $\mathrm{g} \mathrm{k} \mathrm{a} \mathrm{t} \mathrm{-} \mathrm{zich} \mathrm{oprichten,}$ k a k a t - opbreken, openbreken.

Jav. k u m ě d - vrekkig, wortel k ĕd, waarvan k ěk ĕ d - schriel. Van verwanten wortel kud: k ukud - bijeengepakt, Soend. met de vingers of met de hand iets naar zich toe halen, inhalig zijn, de

1) Over reduplicatie van wortels wordt in het volgende hoofdstuk gesproken.

2) P. W. Schmidt, Die Mon-Khmer Völker, blz. 143 - Brunswijk 1906. 
beteekenis van den wortel is ,tegen iets aan, contact hebbende", cf. Soend. k ěk ěd - iets ergens op doen steunen, k eked - kromgetrokken, v. vingers door rheumatiek, wangkid - grens, ta ng kod zich vastklemmen, kokod - hand (grof), B.M. gakod - binden. - Jav. d u m u k - tot aan, in den wortel ligt de beteekenis : tref, een tref, cf. Jav. anduk - treffen, willen treffen, Soend. t j unduk aankomen.

Jav. g u m ĕ r - luidruchtig, luidruchtigheid, wortel g ĕ r, gezegd van luid gelach, Soend. u.b. van surak - juichen enz., in het algemeen een inzettend gedruisch aangevende, dus voor woorden als: vallen van den regen, spelen van een orkest. - Jav. d jumog - neer-, terechtkomen, wortel djog, nog in gebruik in den zin van „ergens gekomen, beland", vgl. a n d jog - uitkomen op.

Mal. $1 \mathrm{u} \mathrm{m}$ a s - besmeerd, in den wortel 1 a s ligt de beteekenis ,een smeer, een veeg over iets", cf. Soend. p u la s - insmeren, besmeren, witten. - Mal. $1 \mathrm{um} \mathrm{ur}$ - besmeerd, de wortel $1 \mathrm{ur}$ heeft ongeveer dezelfde beteekenis als 1 a s, cf. Soend. b a 1 u r - insmeren.

Jav. s u m e h - vriendelijk, minzaam, v. iemands uitdrukking van gelaat, wortel is $\mathrm{seh}$, waarvan $\mathrm{njeh}$, Soend. u.b. vóór: i mut glimlachen, sö ri - lachen.

Jav. lumung - sierlijk gebogen, de wortel lung is nog in gebruik, beteekent „rank”.

Day. suma p - in waterdamp gekookt [gestoomd], wortel sap. Vgl. Soend. a sö pa n, het kegelvormig mandje waarin de rijst gaargestoomd wordt, wortel söp, waarvan sösöp - opzuigen, Jav. s ěs ěp - in-, uitgezogen, geabsorbeerd, gezoogd, de beteekenis ,,geborgen, verborgen in, tusschen", is verder afgeweken, Soend. zuigen, inzuigen, rooken, Mal. is a p - zuigen, in-, opzuigen. De benaming s u m a p ziet dus op het opnemen van stoom door de rijst.

k.uman - eten, wortel kan.

Fidji $1 \mathrm{umil}$ u mis a - glimmend, blinkend, gepolijst, gw. $1 \mathrm{u}$ $\mathrm{mi}(\mathrm{s})$ van wortel $1 \mathrm{is}$, aanwezig in Day. $1 \mathrm{a} 1 \mathrm{i}$ s ěn, malis ĕn, ba 1 i s ěn - glad, glimmend (V. G. V. 52), Soend. g öl i s - schoon v. gelaat; $\mathrm{v}$, vrouwen.

Mlg. š u m u, in: š u m u n d r a ra - borsten van een jonge dochter (Ferrand, Phonétique comparée du malais et des dialectes malgaches p. 67. - Parijs 1909), wortel s u, waarvan s u s u, Austron. - borsten.

Tag. $1 \mathrm{u}$ mó - zwakkeling, van een wortel 1 o ( $1 \mathrm{u}$ ) waarvan ook Tag. I u n o - onrijp, zacht, week. 
Voorbeelden van infigeering van -in-in wortels: Jav. $d \mathrm{j}$ in ĕm - stil en teruggetrokken; de wortel $\mathrm{dj}$ ĕm houd ik voor een variant van $d \mathrm{j} \check{\mathrm{e}} \mathrm{p}$ (evenals $\mathrm{k} \check{\mathrm{e}} \mathrm{m}$ van $\mathrm{k} \check{\mathrm{e}} \mathrm{p}$, wisseling van tenuis en homonyme nasaal als slotconsonant), Soend. u.b. vóór woorden die ,zwijgen, stil zijn” beteekenen.

1 in ěd - angevloeid slib, in den wortel lěd ligt de beteekenis ,door iets anders meegeyoerd, bij iets anders aangewassen”, cf. w a lĕd - aanslibbing, aangeslibd. Van verwanten wortel: li nud vergezeld van (d.w.z. in zijn gevolg), Oud-Jav. meegesleept, ěl ud is thans gw. van ,volgen, achtervolgen”, cf. kělud - veger, $1 \mathrm{ulud} \mathrm{-}$ meegevend, g u l u d - aangeaard. Vgl. nog met variant: palid - door den stroom meegevoerd.

r in e h - kalm, het niet druk hebben, wortel re h - wijze waarop iets [naar behooren] geschiedt, s a r e h - bedaard, rustig.

țin ik țin ik - popperig klein, wortel țik van kloppen, tikken, ook v. droppelen, stippen gezegd, sațițika - een weinig, Soend. sä̈tik-idem, 1ötik - klein.

minuk-minuk - goed doorvoed, zwaar, de wortel is $\mathrm{muk}$, zelf genasaleerde wortel van $\mathrm{p} \mathrm{u} \mathrm{k}{ }^{1}$ ), cf. Mal. $g$ ĕ $m u k=g$ ĕp uk dik, vet.

Soend. li n u - snerpend van pijn, de wortel $l \mathrm{u}$ (een andere dan boven) is aanwezig in Mal. $\mathrm{ng} \mathrm{g} \mathrm{l} \mathrm{lu}$ - een drukkend gevoel op het hoofd hebben, Jav. idem - hoofdpijn hebben, Mak. ng a 11 o - idem, Tag. ngalo - pijn over het geheele lichaam en in de botten van vermoeienis, Pamp. mang a lo - idem.

Tag. 1 in is - blinken, glad zijn, van den wortel $1 \mathrm{is}$, zie boven.

Day. 1 in u s - kaal, glad, cf. Jav. 1 u 1 u s - bestendig, voorspoedig gedijen, Soend. onbelemmerd.

Tag. 1 i n a w - helderheid, transparantheid, klaarheid o.a. van een watervlak (algemeen Filippijnsch), de wortel is la w ( $1 \mathrm{a} \mathrm{u}$ ), waarvan Tag. il a w - licht, schijnsel, Mal. hila u - terugkaatsing of flikkering van het licht op het water, op regendruppels enz., Mal. k i l a u - glans, weerkaatsing, Mal.běla u - b ěla u - flikkering voor de oogen, Mak. kilo - schitteren, Jav. ng ilo - zich spiegelen, gw. ilo, F. i iloil o - spiegel.

Day. rin ot - uit elkaar geplukt, in den wortel rot ligt de beteekenis ,uit elkaar”, cf. Soend. t jor ot - spatten, porot - loslaten, s o r ot - straal, de variant $r$ ut is Soend. u.b. van $\mathrm{ng}$ is in $\mathrm{g}$ - schijten;

1) De genasaleerde wortels worden in hoofdstuk III behandeld. 
s in a t - versperd, verstopt, van wortel s a t, cf. Soend. kĕs àt stroef op de tong, met varianten: sös öt - stroef, Soend. Mal. kus u t - in de war.

$\mathrm{katinik}$ - een druppel, een weinig, is $\mathrm{ka}+\mathrm{tinik}$, van wortel tik, zie boven Jav. ținik ținik.

Day. $\mathrm{t}$ i n o - aangebrand, wortel is $\mathrm{t} \mathrm{ung}, \mathrm{t} \mathrm{u}, \mathrm{t} \mathrm{u} \mathrm{n}$, Sang. $\mathrm{t}$ i $\mathrm{n} \mathrm{ung}$ of t in un - gezoden, Soend. t u t ung - gezengd, aangebrard, zie V. G. V 84, Tag. 1 u t o - koken. - M. t ö̀ - koken, Khm. ț $\tilde{\bar{a}}$ - verwarmen, koken, Bhn. t ŏ.

Boeg. sining - alle, van s ing, Soend. iedereen, Jav. degeen die.

Bat. Mand. bi n on g - vol staande met water, wortel bo n g, cf. Jav., Mal. k ĕ m bu ng - opgezet, Mal. g ĕ m bung - idem, Soend. bĕn g běng - op één hoogte blijven (water dat niet wegloopt), versterkte wortel blěng, u.b. vóór b a r öh - opgezwollen.

$\mathrm{Tb}$. ri n ěp - dicht, v. planken welke nauwsluitend aan elkander gevoegd zijn, Soend. röp, u.b. v. pöröm - gesloten, v. d. oogen, pa röm - gedoofd.

Bat. Mand. 1 in o m, als gw. beschouwd waarvan mang a 1 in o m de oogen onder water openen, van wortel 1 ěm - het diepe, inwendig; Bat. Mand. li n op - ondergedompeld, de wortel lĕp is gelijk aan 1 ěm.

Bat. Kar. p in ět - dicht, v. weefsel, wortel pĕt, bet. „dicht”, cf. Soend. pĕpĕt - goed dicht, Soend. Jav. r a p ĕt - goed aangesloten, Mal., Bat. Kar. r a p a - idem en verdere varianten.

Voorbeelden van infigeering van - an - in wortels.

$\mathrm{P}$. Schmidt merkt omtrent het infix - $\mathrm{n}$ - in de Austro-aziatische talen op dat het bij voorkeur voor de vorming van instrumentale substantieven en abstracta gebezigd wordt, dat het gebruik ook in de Austronesische talen voorkomt maar het infix hier vaker participia perfecta passiva vormt, wat ook in het Bahnar voorkomt en dat het in de meeste Austro-aziatisch talen van Vóór- en Achter-Indië adjectieven vormt (o.c. p. 43). Van een en ander volgen, wat de Austronesische talen betreft, hier enkele voorbeelden.

Jav., Mal., Day. panah - boog, pij1, schot, Tag. pána, Bis. p a ná - pijl en boog; daarmee schieten, Soend. pijl en boog, pijl, F. va na - schieten, Sam. f a n a - geweer, schieten enz., Mon pō h, $\mathrm{p}$ a $\mathrm{h}$ - steenen werpen met een boog, Khmer p o h - werpen, slingeren, kaarden, Mon p nōh - de boog, Khmer phnō h - kaarde, Bahnar pö n a h, p a n a h - met den boog schieten; Austron. p a n a h drukt dus 
het instrument waarmee geschoten wordt uit. De wortel pah is aanwezig in Indon. s u m pa h - eed, Tag. sumpa - vloek (De Indonesische eed is een vervloekingseed), Mal. pěpah - met een lang voorwerp naar iets slaan. De verwante wortels $\mathrm{pöh}, \mathrm{puh}$ komen voor in Soend. pöpöh $=$ pupuh - slaan, pĕrang pupuh strijd, tweegevecht, ook Jav., t j a m p u h - handgemeen, Tag. h i po tik, stok v. e. blinde, i po-i po - wervelwind.

Indon. kanan - rechts, rechter-, letterlijk ,waarmee gegeten wordt" (De Indonesiër eet met de rechterhand). De juistheid dezer verklaring wordt op aardige wijze bevestigd door het Tontemboan, in welke taal de reduplicatie instrumentalen vormt. Welnu, ,rechts” is in het Tontemboan $\mathrm{kakan}$.

In de volgende gevallen heeft de - a n - afleiding de waarde van een verleden deelwoord. Er werd reeds opgemerkt (boven blz. 280) dat dit meebrengt dat het woord ook als naamwoord kan optreden. In het Jav. en steeds in het Mal. voegt men - a n toe als het woord substantief is, in het Soendaasch behoeft dat niet zoo te zijn. Men zegt: lobana pělak kopi sajuta tangkal - het antal koffieboomen dat aangeplant is geworden (verbaal gedacht) bedraagt één millioen, maar: p ěl a k a d j ĕn g a n - uw aanplant (nominaal, statisch). Zoo is

Austron. t a n a m, t a n ĕ m, gw. v. planten, in den grond zetten, begraven, Maori t a n u - begraven, Mon t n a - plant, de wortel is t a m, Stieng - planten, in den grond zetten, Khmer. t $\tilde{\bar{a}}$ - idem (Schmidt o.c.p. 133). Voor O.Jav. t a n ĕm wordt in Juynboll's Woordenlijst opgegeven : ,het planten, het geplant zijn”, t a n ě m a n - aanplanting, doeh oorspronkelijk moet ta n ěm zoowel ",geplant”, als ,het geplante" beteekend hebben, gelijk met Soend. pělak nog het geval is.

Mal. t a nak - rijst in water koken, Bat. Mand. door koking olie of vet bereiden, Tag. groene rijst roosten, Day. gesmoord (vleeschbereiding), Mal. lo ta k - week, slap, zacht, Bat. Mand. l u nt a k tot modder fijn trappen. Mak. ta na' - smelten, ta n a' min ja' bezinksel v. klappermelk, Tb. $\mathrm{t}$ a $\mathrm{n}$ a $\mathrm{k}$ - bezinken, beklijven. Mogelijk van een wortel tak, doch onzeker daar de beteekenissen elkaar niet geheel dekken.

Bat. Toba, Mand. ta no, Bat. Kar. $t$ a n ěh, Soend. $t a n$ öh grond, aarde. Wortel is těh, töh, vgl. Bhn. teh, St. tẽ h, Mn. ti, doch Khm. ț i j.

Austron. a nak - kind, vóór een klinker is het infix prefix; a $\mathrm{k}$ is de oudste vorm van het pers. vnw. le pers. (deze Bijdragen dl. 98 
blz. 249), a n a k beteekent dus letterlijk ,als het zijne erkend, het als het zijne erkende"; dit komt overeen met dia k u, zooals men thans zegt.

Day. s a n a n - aangezegd, verteld, wortel s a n, waarvan met infix - um-suman - idem. De passieve beteekenis van het laatste is vreemd.

Bat. Mand. 1 a n o m - goed ingedreven, v. e .spijker in het hout, in den wortel 1 ĕ $\mathrm{m}$ ligt de beteekenis ,het diepe, inwendig”.

Jav. wan uh - gemeenzaam bekend, van een wortel w uh, waarvan waw uh - idem, en wĕr uh - kennen, weten; Jav. d j a n u r, zie onder $\mathrm{n} \mathrm{j} \mathrm{i} \mathrm{u} \mathrm{r,} \mathrm{blz.} 343$ v.v.

Mal. da n a u - meer, watervlak, wortel da u. Dit is de zelfde wortel als in Tag. $1 \mathrm{ina}$ u (boven blz. 293) en de beteekenis is in den grond dezelfde: door het licht aangedaan, helder, klaar, licht weerkaatsend. De klanken van de reeks $l-r-d$ wisselen gemakkelijk, bv. Tag., Bis., Bkl., Ilk., Sulu la naw en danaw - meer, Mgd. la naw, Png. danaw, Pmp. danao (dano), naast Mal. dan a u staat het meer R a na u in Palembang, Soend. dano-meer, plas, Jav. ra nu - bergmeer, Tont. r a n u - water, rivier, in deze taal is aan het begin van een woord $r$ steeds de vervangster van $d$ (Adriani, Spraakkunst blz. 35 v.v.). Cf. Tag. du râ $=1$ u râ - speeksel, Mal. 1 u dah; Mal. da hi - voorhoofd, Jav. rahi - aangezicht, Jav. ḍ̆mĕn $=$ rĕmĕn - behagen( subst.), in iets behagen vinden, enz.

Oudtijds zijn m- en -n- nog door andere klinkers voorafgegaan in wortels geinfigeerd, hiervan zijn enkele sporen overgebleven.

- a m- Jav. djamak - algemeen, gemeenlijk, van wortel $\mathrm{djak}$ dat de beteekenis heeft "met den voet op den grond drukken”, vandaar: „vaststaande, algemeen” van eenig gebruik, Mal. djědjak trede, s ĕ d j a k, s ĕnd j a k - sedert, sinds (van af het vaststaande moment, het moment van bekend worden), Soend. s ědja k - manier, Jav. $\mathrm{dj}$ ĕ d ja k - den voet zetten op. Met infix - in - van den zelfden wortel: Mal. Jav, d j in a k - tam (getemd).

Austron. d a m a r - hars, licht, Khmer ǵ a r, hars, Bahnar ǵ a r boomsap, Stieng g á $\mathrm{r}$ - hars, boomsap.

Jav. 1 a muk - waas, wazig, O.-Jav. bedekt, als de maan door een dunne wolk, wortel is $1 \mathrm{uk}$, waarin de beteekenis ligt van ,licht bedekken"; met denzelfden wortel: Jav. b ělu k - damp, nevel (die iets bedekt), g ěl u k - damp, walm, k ělu k - damp, rook (v. tabak enz.), Soend. bul u k a n' - beschimmeld, Soend. 1 uluk - slik op den bodem, 
v. e. vijver, v. e. put, Bat. Mand. zwam op den stam van de suikerpalm, afgeschrapt als tondel gebruikt, Bat. Karo idem, Day. s a m $\mathrm{pulok}$ - damp, uitwaseming.

Jav. d a m a n g - iets goed begrepen hebben, O.-Jav. d a n g - doorzichtig.

Jav. 1 a mong - ijlhoofdig, wortel 1 ong, B.M. bu p ong - bedwelmen; met varianten: Jav. kilung - zich onwetend houden, Soend. ling 1 ung - vergeetachtig, Jav., Soend. lĕng 1 ĕng - verbijsterd van zinnen, 1 ĕ $\mathrm{n}$ g is Soend. u.b. vóór: in zwijm vallen enz.

- im-Jav. djimrah - algemeen gebruikelijk, wortel is $d j r a h$, waarvan a ndjrah - overal verspreid, Soend. sawah kör a n d j ra h - er wordt allerwege op de sawahs geoogst (als de oogst in vollen gang is).

Tag., Bis. $1 \mathrm{imot}$ - vergeetachtigheid, Ilk. limed - in het geheim, occult, Bkl. $1 \mathrm{imod} \mathrm{-} \mathrm{in} \mathrm{het} \mathrm{geheim} \mathrm{eten,} \mathrm{Pmp.} \mathrm{a} 1 \mathrm{imit} \mathrm{-}$ iets in het geheim gezegd of gedaan, $1 \mathrm{imid}=$ Bkl. $1 \mathrm{imod}$. De wortels 1 - (vocaal) - $t$ (d) zijn verwant maar niet gelijk wat den klinker betreft, $t$ en $d$ kunnen als slotconsonant wisselen. Cf. Soend. 1 a t, u.b. vóór: vergeten, zich niet herinneren, verdwenen.

- ĕ $\mathrm{m}$ - Mal. kĕ m a s - gepakt in iets, klaar voor iets, eig. in ingepakten staat, voor wortel k a s, zie boven blz. 285 .

Mal. k ĕma m- in den gesloten mond houden, de wortel k ĕm $=\mathrm{k}$ ĕ $\mathrm{p}$ (V. G. V 40), cf. Mal. bung k a m - tijdelijk van de spraak heroofd, Sdend. bungkĕm - muilbanden, Jav. iemand den mond dicht houden.

Jav. k ěm it - dienst als nachtwacht verrichten ten huize v. e. aanzienlijke, de wortel kit beteekent ,dicht bij elkaar, aan elkaar verbonden", evenals de vele varianten, cf. Soend. rakit - aangebonden. Mal. ikut - volgen, Soend. dököt - nabij, Jav. lengket - vlak tegen elkaar vast zitten, enz. De oorspronkelijke beteekenis van k ĕ$\mathrm{m}$ it is dus: een persoon die zich in de nabijheid van een ander ophoudt, als volgeling, ter bewaking.

- ĕ n - Mal. s ĕn a k - benauwd door ophooping van stoffen, wortel sak of š̌k, Jav. sěsak en sĕs ĕk - te nauw, klemmen, Soend. sĕ s ě k - beklemd, benauwd, cf. Mal. man g a s a k - verdringen, Tb. s u měk s ěk - dicht aan elkander.

Jav. Mal. tĕn un - weven, wortel is t un, waarvan Soend. un t u n - vlecht, Cf. Khm. pa nțāń - vlechten, Bhn. tān - weven, vlechten, St. $\mathrm{tan}$ - weven. Er is een wortel $\mathrm{tun}$, waarin de beteekenis „laten zakken, neerlaten" ligt (V. G. IV 317), het is echter de vraag of 
dat dezelfde wortel is. Men kan eerder aan t u n, wortel v. geleiden denken.

Jav. ĕn ĕs - verdriet hebben, wortel ĕs waarvan O.-Jav. ng ĕs $n g$ ěs - neerslachtig zijn.

Tont pĕn ěs - stil, zwijgend, pĕs is Soend. u.b. vóór: d i p a r ö ma n - gedoofd, pěp ěs - dooven.

Tb. pěnĕt, Tag. pinid - toe doen, de deur dichtmaken, Bis. po nod = ,barra”; in den wortel pĕt, pĕd ligt de beteekenis ,,dicht aansluitend", cf. Jav. r a pĕt - dichtgesloten, enz.

Tb. 1 ěn a s - rein, van den wortel 1 a s - op, weg, zie nog beneden onder - un -.

Jav. d jĕnĕng - stand, het staan; de wortel beteekent ,recht staand, recht omhoog", Soend. lěnd j ĕng - recht naar de hoogte.

- un - Jav., Soend. 1 un as - voldaan, afbetaald, van den reeds genoemden wortel las - op, weg, voorkomende in Jav. tělas - op, voorts in het Soend. u.b. vóór: dibalur - ergens mede besmeerd, d i ula s a n - besmeerd, gewit, geverfd zóó dat het voorwerp ermee bedekt is, de beteekenis van u la s is dus eigenlijk, ,het oorspronkelijk aanzien wegmaken, afdekken". Varianten zijn : 1 ěs, Soend. u.b. van : ,weg, verdwenen, bewusteloos, overleden”; 1 os, Soend. u.b. van: ,heengaan, maken dat men wegkomt, overleden.

Van denzelfden wortel met infix - ěn - : Soend. 1 ěn a s - niet zijn, weg zijn; met infix - a n-1anas - wormpje dat meel uit de knol van aardvruchten eet, d.i. waardoor zij lens worden.

Austron. t u n u - branden, wortel t $\mathrm{u}$ - gezengd, aangebrand (V. G. V 84).

Soend. t un un - aan een draad rijgen, van een anderen wortel t u n waarin de beteekenis ,geleiden, tot leiddraad strekken" ligt, cf. $\mathrm{t}$ u n g t u n - geleiden.

Tb. ku nut - iets vast grijpen, aan het haar trekken, de wortel is $\mathrm{k} \mathrm{ut}$ dat evenals de nevenvormen ,,aan elkaar verbonden, dicht bij elkaar" beteekent. .

Mal. enz. bunuh - dooden, Boeg. w unu; in buh (wuh) ligt de beteekenis ,vallen” (V. G. V 75, 78), de letterlijke beteekenis is dus ,geveld”.

Tag., Bis. punò - een volkshoofd, Png. pun o - oudtijds hoofd van een groep, van $\mathrm{po}=$ Austron. $\mathrm{p} \mathrm{u}, \mathrm{mpu}$, heer, baas, meester.

Tag. $1 \mathrm{u} \mathrm{no}$, zie boven bij $1 \mathrm{umo}$.

- on-. Jav. on ar- overal verspreid, misschien staat dit voor 
w on a d daar w wel meer afvalt, de wortel zou dan wa $r$ zijn waarvan $\mathrm{uw}$ a $\mathrm{r}$ - algemeen bekend maken.

Deze versteende infixen zijn op de zelfde wijze als de nog gebruikelijke - um-, - in-, - a n, ingevoegd en vertoonen ook hetzelfde karakter. Op dezelfde wijze als door middel dier laatste infixen afleidingen van grondwoorden worden gemaakt, hebben allen gediend om afleidingen van wortels te maken, nu als zelfstandige grondwoorden, een enkel maal als grondwoord in engeren zin, d.w.z. een nader affix behoevende, in gebruik.

Andere infixen zijn $r$ en $l$. Beider waarde is een meervoud, intensief of frequentatief te vormen, samen te vatten onder den naam ,,sterke vorm”. De invoeging geschiedt, als bij $m$ en $n$, tusschen de beginconsonant en volgenden klinker van het grondwoord. Er is geen onderscheid in het gebruik van beide infixen, zij zijn gelijkwaardig en treden wel in elkaars plaats: Jav. blongs ong = brongs ong - overtrek, vlechtwerk ter bescherming. De enkele consonant kan alleen ingevoégd worden in talen die geen bezwaar maken tegen het uitspreken van twee opvolgende consonanten (nasalen daargelaten) waarvan de tweede een vloeiletter is, met name in het Javaansch. Elders wordt tusschen beginconsonant en $r$ of $l$ een scheidklinker ingeschoven. De normale klank is $a$ maar andere klinkers komen veelvuldig voor, somtijds van volgende klinkers volgens bepaalde regels afhankelijk, somtijds is geen regel aan te geven. In allen gevalle heeft de klinkerwisseling alleen fonetische beteekenis, men kan dus stellen: $-\mathrm{r}-=-\mathrm{ar}-=-\mathrm{e} \mathrm{r}-$ enz., evenzoo: $-\mathrm{r}-=-1-$, - a $\mathrm{r}-=-\mathrm{a} 1-\mathrm{enz}$.

In het Soendaasch is - a r -, - a 1-, altijd met den klinker $a$, levend meervoudprefix. 't Gebruik is zeer vrij, 't formatief kan bij alle woordsoorten ingevoegd worden: $\mathrm{budak}$, barudak - knapen, t ihöla - ti h a röla - vooraan (velen), didi jö, dida ri jö - alhier (van velen). Een aldus meervoudig gemaakt werkwoord kan op een meervoud van subject, van object en van handeling zien, of een combinatie van dezen, maröli, van möli - koopen, kan dus bedoelen, al naar het zinsverband is: velen koopen, iemand koopt vele zaken, er wordt herhaaldelijk gekocht. Zoo ook bij eigenschapswoorden: ing gis - beangst, a ringgis - velen zijn beangst, iemand heeft vele angsten. In bepaalde gevallen, in het bizonder wanneer het grondwoord op - $r$ uitgaat of met 1 - aanvangt, luidt het infix -a 1-: $\mathrm{ma} \mathrm{la} \mathrm{jar,} \mathrm{van} \mathrm{ma} \mathrm{ja} \mathrm{r} \mathrm{-} \mathrm{betalen,} \mathrm{ka} \mathrm{pa} \mathrm{la} \mathrm{sa} \mathrm{r} \mathrm{-} \mathrm{(wij} \mathrm{gaan)} \mathrm{naar}$ de pasar, 1a lömpang, van $10 ̈ \mathrm{mpang}$ - gaan. 
Het Dajaksch kent een prefix ba ra - dat nadrukkelijker is dan ba: babalik - een weinig omgekeerd, barabalik - gansch omgekeerd, a ku barahuma - ik heb een huis, zelden a kubahuma, in andere gevallen weer gebruikt men ba- en ba r a - door elkaar (Hardeland, Spraakkunst blz. 29 v.v.). B a ra-bevat geen infix - a r -, het is een dubbelprefix, bestaande uit ba- + ra-, ra-is de meervoudsvormer als prefix. Zooals bekend komt dit $\mathrm{ra}$ - over het gansche Austronesische taalgebied als meervoud resp. honorifiek prefix voor. In het Soendaasch vormt het het meervoud van umpak basa: bul vóór: (aankomen), rabulidem, v. velen.

Voor het overige maakt $r, l$, c.q. - $a r-,-a l$-, enz. van de woorden waarin het voorkomt een vast bestanddeel uit, dat niet, als de genoemde Soendasche meervoudsvorm, naar willekeur kan ingevoegd en weggelaten worden. Met dat al is het gevoel voor het emphatische van den geinfigeerden vorm in meerdere of mindere mate behouden, wat hierin uitkomt dat de sterke vorm somtijds als krachtiger dan de niet-sterke daarnaast in gebruik is. Men zou zulke sterke vormen secundaire grondwoorden kunnen noemen, als men wist dat de sterke vorm van den niet-sterken was afgeleid, dat is meestal onbewijsbaar en behoeft zelfs in het geheel niet het geval te zijn geweest, hij kan als zoodanig uit den wortel zijn ontstaan. (Vgl. hiervoor het in ,De Soendasche umpak basa”, d1. 102 dezer Bijdragen, opgemerkte). Voorbeelden: Soend. g e r e leng en ga releng - rollen, g e l eng - omdraaien intr., rijden over, draaien om; wanneer het eigenlijke gw. in beide syllaben den zelfden klinker heeft, wordt die van het infix in deze taal gewoonlijk daaraan geassimileerd, doch $a$ blijft ook wel behouden; piringkil - krinkelen, *pingkil komt niet voor. In Javaansche geschriften is de sterke vorm wel drielettergrepig, de vocaal van het infix is dan gewoonlijk $a$ of, verdoft, $\breve{e}$, de gesproken taal volstaat, als gezegd, met de enkele consonant, maar een breedere uitspraak met $\breve{e}$ komt toch ook voor. Het $\mathrm{Wb}$. is in dit opzicht willekeurig, geeft tĕrant j a ng naast $\mathrm{trant} \mathrm{jang}$-doorzichtig, ta ri $n t j i n g$ naast $t r i n t j$ ing - vlug en los, v. beweging, naast $t a l u t u h$ geen $t 1 \mathrm{utuh}$ - voortgevloeid. Pigeaud geeft doorloopend den vorm met enkel de consonant. Naast g o m bol staat ga rombol (in poëzie) -struikgewas $=\mathrm{grumbul}$ waarnaast ${ }^{*} \mathrm{gumbul}$ ontbreekt. $\mathrm{T} \mathrm{j}$ a ng a p - de gaping van een open muil, is onderscheiden van tj la n g a p - wijde mond v. e. put of grot, opening, breedte tusschen de oevers, breedte tusschen de boorden v. e. prauw, kanaal of uitwatering uit een rivier naar zee; $\mathrm{t} 1$ o r e $\mathrm{n}$ g - gestreept als een tijger, 
tjoreng - vuile vlek, Mal. t juring - streep; djroṇ i i is bepaaldelijk frequentatief van $\mathrm{dj}$ on nd $\mathrm{i} 1$ - het achterste in de hoogte gooien. Overigens valt te rekenen met de mogelijkheid dat de quasiniet-sterke vorm slechts een verzwakte uitspraak van den sterken is, men zegt ook pija ji voor $\mathrm{prijaji,} \mathrm{Panaraga} \mathrm{voor} \mathrm{Prana-}$ ra ga enz. - Het Maleisch heeft steeds - ĕr - of -ě I-: g ĕlakak schateren, vgl. Soend. t j a k a k a k; g ĕlĕt a r - bibberen, sidderen = g ĕ t a r - sidderen, beven, daveren, Jav. g ět ĕ r - beven, de p ěp ĕ t van het infix is hier oorspronkelijk; g ĕlig i t wordt als herhaling van gigit - bijten, opgegeven, schijnt dus als frequentatief in gebruik; kĕrosok - ritselen, schuifelen, Soend. koros ok, eenige vorm. De $\breve{e}$ is in de beide laatste gevallen uit a of den homonymen klinker verdoft. Het Dajaksch heeft - a r - : g a ris i k ritselen, ${ }^{*}$ g i s i k ontbreekt, ga raga p - geraas maken, *ga ga p ontbreekt. - Het Tontemboan heeft - a r -, - a 1-, ook met anderen klinker: ke'ke' lachen, k a l e' k e' - freq.; k a le' ke w (Tons. ka lĕw k ěw) - spartelen, *ke'ke w ontbreekt; k ělis it $=$ k ul is it - gekruld, v. bladeren, groenten, geen grondwoord; k ĕ r ĕ s ĕ $\mathrm{m}$ - scherp, zuur, geen grondwoord, wortel is s ěm. - In het Tagalog zijn - a r - en - a 1samengevallen in -a 1-, andere Filippijnsche talen kennen beiden.

Voorbeelden: Tag. g a la g a d - de armen bewegen, grondwoord ontbreekt, er is een wortel $\mathrm{g}$ a r waarin de beteekenis ,los staan, met ruimte" ligt, b.v. Soend. 1 u g a r - losgaan, b.v. het haar, Mal. 1 e g a $r$ - ruimte om zich te kunnen verroeren, Tont. g o g a r, og a r - losmaken. Cf. Soend. 1 o g o r - los zittend (spijker in een gat, kleeding), Jav. la g u r - uitvallen, v. bloembladeren; Tag. ha $1 \mathrm{ak} \mathrm{hak}$ - in lachen uitbarsten, grondwoord ontbreekt; Png. Pmp. g a la kg á k, Ilk. g a ra kgák - luid gelach; Tag. pa la k pák, Bis. Hil., Bkl. pa lakpak - applaus, Bis. Sam. Ley. parakpak - idem, is van. een wortẹl p a k, Soend. u.b. vóór: uitbarsten v. e. geluid; een enkel maal komt - a g - voor: Tag. s a $\mathrm{g}$ i t s i t-geraas, door braden gemaakt, Mal. t j it j it - piepen, v. muizen, v. iets dat brandt.

De klanken $r$ en $l$ worden nog op andere wijze als infixen aangewend, thans als twee onderscheiden klanken, in dier voege dat bv. - a $\mathrm{r}$ - of - a l-, in een zelfde grondwoord ingevoegd, verschillende woorden vormen.

Een wijziging der beteekenis van het grondwoord in bepaalde richting is niet aan te geven, men kan slechts zeggen dat de afleiding van het grondwoord afwijkt en dit is dan nog alleen mogelijk als de be- 
teekenis van het laatste bekend is. Immers, het woord zonder infix ontbreekt veelal. Verder komt het ook voor dat de beteekenissen van grondwoord en geinfigeerden vorm niet verschillen.

Bestaat er een sterke vorm van een grondwoord, dan kan het zijn dat hij niet alleen het begrip van het grondwoord op intensieve wijze of als frequentatief vertolkt, maar tevens in de toepassing van beide woorden, bv. wat betreft de voorwerpen waarvan zij gebezigd worden, in het spraakgebruik verschil wordt gemaakt. De grens met beteekeniswijzigend - a r - of - a 1 - is dan niet altijd meer te trekken. Zoo is van Soend. gěndĕng - pruttelen, grommen, het frequentatief g ĕ lĕ nd ĕng, doch gĕr ĕnd ěng, kennelijk hetzelfde, is ,,doffe klank, geluid van spreken in een aangrenzend vertrek; Soend. gila p is „blinken”, g u rila p - licht van zich geven, enz.

Hier volgen thans eenige voorbeelden van door infigeering van $r$ en $l$, al dan niet door een vocaal voorafgegaan, gevormde nieuwe woorden. 't Aantal is onbeperkt.

Jav. platjěk - (rij)paaltjes (op akker om plantwijdte aan te geven) P, p a t j ĕ k - stok, penwortel; p la t u k - specht, p a t u k pikken; plupuh - platgeslagen bamboe, pupuh - gebeuk, gevecht; $\mathrm{s} l \mathrm{a} \mathrm{m}$ p a r - touw met voetlussen, gebruikt bij het beklimmen v. boomen, s a m par - met den voet raken door er snel bij langs te strijken; s la rak - sluitboom, *sarak ontbr.; Soend. djaridji - ringvinger, Jav. djridji, Mal. djari, Tag. daliri' - vinger, het Maleisch is gevormd van den wortel $\mathrm{dj} i$ met infix $-\mathrm{ar}-$, Soend. Jav. Tag. met infix van den herhaalden wortel, het infix is in het Tag. steeds - a 1 - ; Soend. k a r ĕ m b ě n g - cylindervormige rijst - (1. padi-) schuur, Gaj. kĕbön - bergplaats voor padi, bestaande uit een ronde omwanding van boomschors of gevlochten bamboe, staande op een bodem van gevlochten bamboe en van boven gesloten met een deksel, eveneens van gevlochten bamboe, een of meer zijn geplaatst in een, in den regel, op palen gebouwd huisje. In Atjeh hebben deze, aldaar köpō' geheeten bewaarplaatsen een deksel en een bodem van hout, Bat. Kar. kĕ b ĕn ${ }^{1}$ ), Soend. *k ě m b ěn g ontbr., doch vgl. k ěm -

1) Afbeeldingen van zulke bewaarplaatsen in Madjapait, staande op gemetselde voetstukken, in: Galestin, Houtbouw op Oost-Javaansche tempelreliefs, blz. 181, 182. - 's-Gravenhage 1936. Hier staan zij niet onder afdaken, maar elk heeft een eigen dak. - Open, buikige manden van zeer groote afmetingen, waarin padi bewaard wordt, in principe gelijk aan deze bewaarplaatsen buitenshuis, kan men op Java hier en daar in de huizen aantreffen, zij heeten krĕmběng ! Ook Jav. $1 \mathrm{umbung}$ beteekent zoowel een padischuur als wijde, hooge cylinder v. vlechtwerk, bewaarplaats v. padi binnenshuis, 
b u ng opgezet, gezwollen en K.B.Wb. s.v. k ěmběn g, zie boven blz. 294 s.v. binong; Soend. galabag - zonnehoed van breede bamboereepen, Jav. gabag - zeer grof bamboevlechtwerk; Jav. dlurung, Soend. dalurung en darurung - vloerligger, Jav. durung is een ander woord; Soend. s a l̆ $\mathrm{mpaj}$ - neusdoek, zweetdoek (eig. doekje dat men over den schouder draagt), s a mp a j - hangen over; Soend. b ě lě n in g - zeer schoon (erf), Soend. Jav. bĕ n ing - helder, zuiver; Mal. b ěl a k a n g - achterzijde, achterste deel rug, *b a k a ng ontbreèkt, doch vlg. b o k on $\mathrm{g}$ - achterste voren gekeerd, Jav. achterste (billen), Soend. iets zoo achter zich houden dat het niet gezien wordt bo bo kong - stuit. Mak. bo ko, Boeg. b o k o' - achterdeel, hetgeen achter iemand is; Mal. d j ěr a i t - zich aan iets vasthechten, $d j a(h) i t$ - naaien; Mal. b ěla la ng - sprinkhaan, Jav. w a la ng; Mal. g ěl e be r - omgekruld neerhangen, Soend. g e be r - lel, v. e. haan; Jav. halskwab (rund); Mal. pĕ r ğ k a t - lijm, cement, pěkat - dik, v. vloeistoffen, in den wortel kĕt ligt de beteekenis ,aaneen”. Day. sa la mpai - over den schouder of om den hals gedragen doek, "sampai ontbr., Mal. sampai - hangen op, over $=$ Soend., Day. sampaj; ba ladau - kleine, tweesnijdende dolk, vgl. mandau - zwaard; garigir - horizontale balken of latten aan de wanden v. e. huis, Soend. gi g i r - zijde; Day. ka ra it, $\mathrm{krait}$ - ergens mee vervlochten, ergens in verwikkeld, meegedaan hebben, Mal., Soend. kait - haak; Day. bar untong - afgebroken, Jav. buntung - idem; Day. salisih - verkeerd, Jav. sisih ernaast.

Wanneer het infix woordvormend optreedt, niet als meervoud, schijnt het in het Dayaksch steeds breed te worden uitgesproken: - a 1 -, - a r -

Tont. kěr r ĕ s u t - de naar boven uitpuilende rimpel op het lichaam, ontstaan door stevig binden, Ts. kĕsut - de pit uit een vrucht, de etter uit een wond drukken; kolowit, Ts. kalawit - werpspies met tanden met weerhaken, kow it, Ts. koit - bamboe, gebruikt bij godsd. feesten om er water in te doen, aldus genoemd omdat het open einde schuins is afgesneden; k u ra' is - totaal gebrek hebben aan iets zoodat het als het ware geheel is weggevaagd, ka' i s - vegen, openkappen; kě'k ěs - vleesch enz. in blad gewikkeld, goed stijf met een touw omwonden, k a l ě' k ěs - soort tor, naam gegeven naar de gele strepen die rondom haar lichaam loopen en waarmede het dier als omwonden is; wa ru'mbu' - wond in het oor, wu' $\mathrm{mbu}$ ' een klein gat. Kolowit, kura'is, kalě'kĕs kan men ook als 
sterke vormen opvatten; Ibg. $\mathrm{k} \mathrm{u} \mathrm{ram} \mathrm{a} \mathrm{j} \mathrm{-} \mathrm{vingers,} \mathrm{Bis.} \mathrm{Hil.} \mathrm{kama} \mathrm{j}$ - hand, Iwt. vingers, Bis., Bkl. iemand roepen door met de hand te wuiven. Wortel is $p a j$, genasaleerd, $m$ a j. Iwt. $p a j p a j$ - iemand roepen door met de hand te wuiven, Soend. $\mathrm{g} \mathrm{u} \mathrm{paj-idem} \mathrm{door} \mathrm{met}$ de hand te wenken, Tag. pa j paj - waaien, Tag. ka pa j - de hand bewegen, enz.; kala baw - buffel, Jav. kĕbo, Mal. kĕrba u, Bat. Kar. kĕrbo, Tag. kabaw - spieren (nervio) v. d. buffel; ka liwa' - linkerhand, Jav. kiw a - links, linker. Het infix beteekent niet altijd verandering: Tag. $\mathrm{kalawit}=\mathrm{kaw}$ it - haak, Tb. ka it haak en vgl. boven Day. karait, Bis. Sam. Ley., Mgd. kawit $=$ kahit - haak, Bkl. kawit - haak doch kalawit harpoen; Tag. s a li p s i p - iets tusschen huid en vleesch plaatsen, s i p sip - zuigen, in den wortel sip en nevenvormen ligt de beteekenis „binnengaan, in iets gaan”; Tag. d a 1 a g a - jonge vrouw, Bis. Sam. Ley., Bkl. da r a ga Mal. d a r a - maagd, Jav. ḍ a r - halfvolwassen, Soend. d a r a - vrouw die haar eerste kind heeft, ook v. dieren; Tag. p a 1 a ko 1 - bijl, *pa kol ontbr., in den wortel kol, k u 1 ligt de bet. „slaan op iets zóó dat geraas gemaakt wordt”, Soend. t a kol - met een voorwerp slaan, bv. op een slaginstrument, Jav. kulkul - seinblok.

Evenals dat bij de infixen $m$ en $n$ het geval was, komen $r$ en $l$ ook in wortels geinfigeerd voor. Voor wat het maken van sterke vormen van wortels betreft, kan op de Soendasche umpak basa gewezen worden. Het infix bestaat uit de enkele consonant en $r$ en $l$ zijn gelijkwaardig. In het artikel over de Soendasche umpak basa waarheen verder wordt verwezen (deel 102 dezer Bijdragen blz. 81 v.v.) is reeds opgemerkt dat er tusschen gewonen en sterken vorm nauwelijks verschil is. Dit laat zich begrijpen daar het aanwenden van umpak basa op zichzelf reeds een emphatische wijze van zich uit te drukken is.

Het invoegen van $\mathrm{r}$ en 1 in wortels tot vorming van nieuwe woorden komt eveneens en op zeer uitgebreide schaal voor. In dit geval is het infix steeds vocaal $+r$, vocaal $+l$ en zijn $l$ en $r$ niet gelijk te stellen. Een verschil met grondwoorden is dat de keuze van klinker tot de beteekenis bijdraagt. 't Is dus niet zoo dat de eene taal bv. -a 1- infigeert en een andere in hetzelfde geval -ěl- en in eenzelfde taal heeft -a 1- een andere uitwerking dan -ěl-, dan - $\mathrm{u} 1$ - enz. 


\section{Voorbeelden :}

Javaansch djaluk - om iets vragen, is wortel djuk met infix - a 1-, andjuk - borgen; bělak (ĕn) - kloven hebben, in huid v. hand of voet, wortel ba k, b a bak - rauw, ontveld, doorgereden, $\mathrm{bubak}$ - den grond omwoelen, rombak, rumbak - verbroken, $\mathrm{b}$ ĕ b a k - tot gruis stampen, in den wortel b a k ligt de beteekenis ,uit elkaar gaan" (er is meer dan één wortel b a k); g i r a s - schuw, wild, g a g a s - zeer ontroerd, door een gedachte gekweld, Soend. zeer bewogen, i n g g i s - beangst, in de wortels $\mathrm{g}$ a s, $\mathrm{g}$ i s ligt de beteekenis van ,bewogen, getroffen, van het gemoed”; t u r u t - volgend, t u t volgend, O.-Jav. $t \bar{u} t$, de omgekeerde ontwikkeling, van $t u r u t$ tot t u t komt mij onaannemelijk voor: t j ulat - voortspringen, Soend. $1 \mathrm{unt}$ j a t - springen, but j a t - doorbreken, uiteenbarsten), Jav. p é $t \mathrm{j}$ a $\mathrm{t}$ - afgescheiden worden $\mathrm{v}$. iets dat aan iets anders verbonden en ermee vereenigd was, losgemaakt uit verband, in den wortel $\mathrm{t} j$ at ligt de bet. ,zich losmaken, v. iets wegspringen”; k u r ě b - holle onderzijde, k ě k ĕ b - los, bol deksel op rijststoommand, t a n g k ĕ b - overslaande klep, in den wortel ligt de beteekenis ,afdekkend met bolle zijde onder". Verwant is kub: Filipp. kulob - onderste boven, Ta ngkubanparahu - de bekende berg die er als een omgekeerde prauw uitziet. Variant is $\mathrm{k} \breve{\mathrm{m}}$ : t ě k ĕm - toegesloten hand.

Soend. d ja rah - in het wild loopende (buffels), randjah - v. dieren, in een aanplant komen en daar schade aanrichten, $\mathrm{djadjah}$ - de ronde doen, Mal. mĕndjaṛhi - plunderen, rooven in den oorlog, wortel $\mathrm{djah}$; $\mathrm{dj}$ irĕt - strik v. touw om dieren te vangen, afleidingen van djět ontbreken in het Soend., Mal. d j ĕrat - strik, strop; vgl. van wortel $\mathrm{d} \mathrm{j}$ ot: $\mathrm{k} \mathrm{o} \mathrm{d} \mathrm{j} \mathrm{o} \mathrm{t} \mathrm{-} \mathrm{zich} \mathrm{verstrikken} \mathrm{en} \mathrm{tuimelen,}$ $\mathrm{g}$ ĕ $\mathrm{d} \mathrm{j} \mathrm{ot} \mathrm{-} \mathrm{een} \mathrm{snellen} \mathrm{ruk} \mathrm{aan} \mathrm{iets} \mathrm{doen,} \mathrm{ĕn} \mathrm{d} \mathrm{j} \mathrm{ot} \mathrm{-} \mathrm{snelle} \mathrm{beweging}$ vóór- en achterwaarts verrichten, u.b. $\mathrm{n} \mathrm{j} \mathrm{od,} \mathrm{van} \mathrm{trekken} \mathrm{a.} \mathrm{e.} \mathrm{sigaar}$ gezegd; d jolor - lang uitgestrekt liggen, londjor - uitgestrekt liggen, met verwante wortels: sanghundjar - zitten met uitgestrekte beenen, b a d jĕ r - boonestaak, tuinstok, löndjö r - lang en recht, u j u r - in het lang, in alle wortels ligt de beteekenis van iets dat een zekere strekking heeft, hierbij sluiten aan: Mal. dj ěla r (wortel d jěr) - uitgestrekt liggen, b.v. een slang, $d \mathrm{j} u 1 \mathrm{ur}$ - recht vooruit steken; g ĕ r u ng - grommen, kreunen, stenen, h a r ĕg u n g, sterke vorm van h ěg u ng - stenen, děg ung - hangende gamĕlan, g u n g, u.b. (slaat de gong). Nevenvormen zijn h a rěg ĕ $\mathrm{m}, \mathrm{g}$ ĕ r ĕ m, wortel g ěm. Cf. Tb. t u n g g o g o n g - suizen, gonzen, fluiten, Soend. g o ng g o ng - blaffen, g o ong (met vocaal splitsing) - een gong. 
Maleisch bila s - afspoelen, uitspoelen, de wortel is b a s - eraf, weg, b a ba s - afgedreven, verstrooid, be bas - vrij, onbelemmerd, Jav. b i ba s - op, k ĕb a s - afslaan v. stof of vuil der kleederen; d j a 1 i r - vloeien, vooral v. gesmolten metaal, Jav. d j i r - smelten door hitte of vuur, ba nd j i r hoogwater; g a li r - los zittend, goed glijdend, wortel is g i r, waarvan geen andere afleidingen bekend zijn, wel van nevenwortels: l e g a r - ruimte om zich te kunnen verroeren, Soend. lo g o r - los zittend, ung g ěr - los staan (tand, boom enz.), de beteekenis van den wortel is "los staan, met ruimte”; zie verder boven blz. 301 bij Tag. s.v. galagad; kurung - kooi, wortel is kung: bĕngkung - omgebogen, Jav. bakungkung - tijgerval, kung k un g - gevangen houden, Soend. d j u n g k u n g - gebukt, d j u k u n g - een vaartuig (naar oploopenden voor- en achtersteven), B.M. (i) t engkong - boogsgewijze gemaakt, Tag. 1 u kóng - concaaf, een variant van den zelfden wortel is $\mathrm{kuk}$, dit komt meer voor, tenuis of muta en homonyme nasaal wisselen als slotconsonant van wortels (boven, Jav..s.v. kurĕ b, kĕb= kĕm), Mal. k uk - juk voor lastdieren, Soend. kuuk (met vocaalsplitsing) - engerling, $\mathrm{kukkuk}$ (Wb. kukuk - fleschvormige kalebas).

Day. kalong - omsingeld, wortel is kong (= elders kung), b a n g k on g - schedel, ba beng kong - krom, k urong - opgesloten; in g k o k - krom. Verwante wortels zijn kang, k ĕng, king, $\mathrm{keng}$, k ong, waarvan vele afleidingen; in allen ligt de beteekenis „gekromd”. Cf. Khm. kang - rad, St. kong. Zie verder boven blz. 282 s.v. mangkuk; ka rap - gegrepen. Wortel is ka p, singkap Day., B.M., Pon., Bent., Tons. singkap - vatten, B.M. kulika pschutbladeren, Day. kakap - bevoelen, betasten. De nevenwortels hebben dezelfde beteekenis: Bis. da k op, Tag. da k i p (wortel kěp) - pakken, enz.

Tont. k i r i n g - gezegd v. e. arm die niet meer recht kan gestrekt worden, kromgetrokken vingers, wortel is king, nevenvorm van $\mathrm{kung}$, waarvoor men zie Mal. kur ung; k u r is - scheren, wortel is ki w waarvan ki' kis - vijl, Tb. kiskis - afkrabben, afscheren, kĕr ĕs - ompakken, omwikkelen, wortel is k ĕs waarvan k ĕ'kĕs, Tons. kĕskĕs - vleesch, tabak, visch, in blad gewikkeld en goed stijf met een touw omwonden, w a w a 'k ĕs (v. w a 'k ěs) - datgene waarmee men iets vastbindt; verwant is kus, Mal. Jav. bungkus - inpakken; s ěr ěp - doordringen tot in alle deelen van iets, wortel is s ěp waarvan Tont. s ě's ěp $=$ opzuigen. De wortel 
met nevenwortels is zeer verbreid, de beteekenis is ,indringen, in iets gaan".

Tag. pulong - menigte, in den wortel pung ligt de beteekenis „,bijeenbrengen, verzamelen, Jav. Soend. gampung - aren lezen, Soend. pang pung' - in menigte komen, Soend. gěm pung - zich verzamelen. De nasalen $n$ en $n g$ wisselen als slotconsonant: Jav. i mpun, Soend. i mpung - verzamelen, Tag. kampóng $=$ kampón clan, stam, volgeling; gilid, tagilid - zijde, wortel is gir, Jav. ping g i r - rand, kant, Jav. gi g i r - rug, bergrug, Soend. gi gi r zijde, Jav. 1 in $g$ i $r$ (met genasaleerden wortel) - scherpe rand, ribbe; palad - handpalm, Soend., Daj. a mpar - uitgestrekt, gespreid, Soend. $1 \mathrm{a} \mathrm{m} \mathrm{par} \mathrm{-} \mathrm{zich} \mathrm{ver} \mathrm{uitstrekken,} \mathrm{g} \mathrm{ĕ} \mathrm{m} \mathrm{par} \mathrm{-} \mathrm{uitgestrekt}$ nederliggen, Jav. 1 ĕm par - vlak, ruim en effen; pul ot - opgepikt, van een wortel pot (put), Jav. djuput - nemen, wegnemen, Mal. d j ěmput - met de vingers iets nemen; Tag., Bis. pa la j, Ilk. pa ga j, Bkl. paroj, palaj, Png. pagé j, Pmp. pale, Iwt. paráj, Soend. pare - rijst in de aar (padi). Ik houd het ervoor dat dit met infix - ar - is afgeleid van een wortel pa j, poj, cf. Khm. pāj - bereide rijst, Bhn. po i. - 't Verschil in beteekenis maakt de gelijkstelling onzeker, maar zulke overgangen van beteekenis zijn niet uitgesloten, bv. Soend. huma - droog rijstyeld op boschgrond, Gaj. umösawah, Soend. me j on g - tijger, doch gewestelijk kat. Een voorbeeld dat palatale en gutturale $r$ verward zijn levert Tag. pigís - samendrukken $=$ wortel p i s met infix -ig-, Bkl. p i r i s, vgl. Jav. dĕp i s - plat weggedoken, Austr. tipis, ip is - dun, Jav. pip is - fijngeweven, op wrijfsteen. Voorts Tag. pigit - nauw, Bis. Seb. pig'it iemands hand drukken, wortel is pit, waarin de beteekenis ,drukken, knijpen" ligt. Een enkel maal komt in het Tag. vocaal $+r$ voor: k u rok - kuikens roepen (algemeen Filippijnsch), ; van den wortel kok, Jav. kokok - geklok v. hanen en hennen, Tag. kukook kakelen; Tag. tig is - sap dat uit de kokospalm vloeit, Mal. tiri s doorsijpelen, wortel is ti s, waarvan Tag. tit is - vloeien v. h. zweet, druppel vóór druppel, Day. Tont. afdruipen.

Evenals voor de infixen $m$ en $n$ geconstateerd werd, blijken de infixen $r$ en $l$ op dezelfde wijze als dat bij grondwoorden het geval is, in een vroeger stadium der taal in wortels te zijn ingevoegd, de aldus geinfigeerde wortels zijn grondwoorden geworden. 


\section{c. Suffixen.}

Er zijn slechts een paar voorbeelden te noemen van wortels waaraan een suffix zóó is vergroeid dat zij thans grondwoorden vormen, nl. Jav. 1 i j a n - ander, anders, van den wortel $1 \mathrm{i}+$ a n (V. G. V 50) en Jav. Soend. kĕtan - kleefrijst, van kĕt + - a n, kĕt, variant van kit (blz. 297), ,aan elkaar verbonden, dicht bij elkaar, cf. Soend. $1 \mathrm{ikĕt} \mathrm{-} \mathrm{kleven,} \mathrm{Jav.} \mathrm{rukĕt} \mathrm{-} \mathrm{nauw} \mathrm{verbonden,} \mathrm{enz.} \mathrm{De} \mathrm{suffixen}$ behooren tot een later stadium van ontwikkeling der Austronésische talen.

Het maken van afleidingen door affigeering van wortels moet geschied zijn in een vroeger tijdperk van het Austronesisch, toen de wortel aansprak als later en nu nog het grondwoord. Men kan hier een vergelijking maken met de Austro-aziatische talen die, in haar ontwikkeling bij de Austronesische achtergebleven, aan den wortel als zelfstandig gebruikt woord nog een ruime plaats toekennen.

\section{Herhaling en reduplicatie.}

Als tweede wijze waarop grondwoorden van wortels zijn afgeleid, noemden wij de herhaling en de reduplicatie.

Herhaling en reduplicatie van grondwoorden zijn in schier alle Austronesische talen nog in zwang of uit het verleden bekend. Van dezen heeft woordherhaling in het algemeen versterkende of verzwakkende beteekenis. De eerste ligt voor de hand: wordt een woord herhaald, dan valt daarop de aandacht, 't begrip zet uit en wordt een meervoud of een intensief. Minder gemakkelijk te begrijpen is het dat de herhaling ook verzwakkend werkt. Men schijnt zich hierbij te moeten voorstellen dat het begrip, door het te herhalen als het ware buiten zijn begrenzing tredende, daardoor minder scherp omlijnd wordt, 't wordt vager, zwakker. De verandering welke de herhaling teweeg brengt, is voor alle woordsoorten niet dezelfde en ook in de verschillende talen ongelijk. Herhaling van een werkwoord kan beteekenen, als zij versterkend werkt, dat de handeling meer dan eens geschiedt, een meervoud dus, maar ook dat zij intensiever plaats vindt, beide begrippen gaan gemakkelijk in elkaar over. Bij substantieven daarentegen vormt de herhaling een meervoud, niet als collectief maar als een verscheidenheid gezien. De verzwakkende beteekenis uit zich bij beide woordsoorten ongeveer op dezelfde wijze. De adjectieven sluiten zich hierbij aan. Hier volgen enkele voorbeelden: Herhaling van een adjectief kan een-meervoud zijn, bv. Mal. roe- 
mah jang běsar běsar - verscheidene huizen, allemaal groot, doch verzwakkende beteekenis komt ook voor, bv. Tont. se kaju an duruan rangka-rangka' se ang kuntung kuntung ja kolě-kolěk - de boomen aan de kust zijn tamelijk hoog, die in de bergstreken (meervoud!) zijn nog al laag (Adriani, Tontemboansche spraakkunst blz. 47) ${ }^{1}$ ). Uit deze voorbeelden blijkt tevens dat bij de woordherhaling klankwijzigingen kunnen optreden zóó dat zij niet volkomen is. Dergelijke wijzigingen, in verschillende talen voorkomende en van uiteenloopenden aard, raken het principe der herhaling niet en kunnen daarom hier onbesproken blijven.

Herhaling van een substantief kan diminutieve beteekenis hebben in het Makassaarsch en Boegineesch, bv. Mak. montjong - berg, montjongmontjong - heuvel; Boeg. bola - huis, bolabola - huisje, kribbe.

In deze talen komt ook diminutieve beteekenis van werkwoorden voor, bv. Mak. renreng - bij de hand leiden, renrengrengreng - zachtjes bij de hand leiden; Boeg. ma'djama - betasten, ma'djamadjama slechts even betasten. 't Zelfde in het F.: yana-yana - los gevlochten, yana $=$ Indon. anam - vlechten (V. G. V 100). Daartegenover staat versterkende beteekenis die eveneens bekend is, bv. Mak. kalatta' bijten, kala kalatta' - met kracht bijten; Boeg. ma'sappa' - zoeken, $m a ' s a p p a^{\prime} s a p p a^{\prime}$ - gedurig zoeken. Het verschil in beteekenis, nl. verzwakkend of versterkend, wordt uitgedrukt door den toon waarop het herhaalde woord uitgesproken wordt (Matthes, Boegineesche spraakkunst blz. 116 - 's-Gravenhage 1875).

Van adjectieven geldt hetzelfde, bv. Mak. kammu - warm, kammukammu - lauw, v. versterkende bet. geen voorbeelden, Boeg. pělla warm, pĕllapĕlla - zeer warm, unji' - geel, unji'unji' - geelachtig, een weinig geel.

'Nog een ander gebruik van de herhaling gemaakt is om van een werkwoord een substantief te maken, bv. Mak. anang gw. - vlechten, ananganang - vlechtwerk, horde; Boeg. taněng gw. - planten, taněngtaněng - plantgewas, boom; omgekeerd worden van adjectieven door herhaling werkw. gemaakt: Mak. tinggi-tinggina pi bulang, terwijl de maan nog hoog aan den hemel staat.

In het Soendaasch werkt de herhaling van een werkwoord versterkend, bv. ngabedjakön - iets berichten, ngabedja-bedjakön -

1) De titel luidt: N. Adriani en M. L. Adriani-Gunning, Eenige hoofdstukken uit de spraakkunst van het Tontemboansch. - 's;-Gravenhage 1908. 
rondbazuinen. (De affixen plegen niet mede te worden herhaald, geschiedt dit toch, dan is de versterking krachtiger.)

Herhaling van een substantief is een meervoud met verscheidenheid, er zijn echter voorbeelden dat zij verzwakkend werkt, bv. ilat tong, ilat ilat - evenaar van een weegschaal. Er is een waarneembaar verschil in intonatie in de twee gevallen, in het eerste geval is er ook een hiaat. De uitspraak van het herhaalde woord in verzwakkende beteekenis staat met woorden die steeds herhaald worden zooals a l u na l u n gelijk. 't Maken van zulke fijne onderscheiden is één der schoonheden der Indonesische talen.

In het Fidji kan de herhaling van een substantief diminutief zijn, bv. buke - berg, bukebuke - een kleine berg; ook versterkend: manumanu - gevogelte, manu ontbreekt.

De reduplicatie zou men een onvolkomen herhaling kunnen noemen.

Een geredupliceerd werkwoord drukt vaak uit dat de handeling zich herhaalt maar deze herhalingen worden tezamen als één beeld gezien. Stelt men de herhaling als een rij evenwijdige, los van elkander staande lijnen voor, dan is de geredupliceerde vorm een zigzaglijn, bv. Soend. tjarita - verhalen, een verhaal doen, tjatjarita - allerlei verhalen. In het Tontemboan zijn de met reduplicatie gevormde zelfstandige naamwoorden zonder uitzondering werktuignamen, bv. ̌̌ $\breve{l e ̆ p ~-~ d r a n k, ~ d a t ~ w a a r m e e ~ m e n ~ d r i n k t, ~ A d j e c t i e v e n ~ m e t ~ r e d u p l i c a t i e ~}$ en achtervoegsel - $a n$ hebben de beteekenis van een betrekkelijk overtreffenden trap, bv. lambat - lang, lalambatan - zeer lang. In het Soendaasch kan de reduplicatie van een werkwoord reflexieve beteekenis hebben, bv.. batěk - uitrekken, uittrekken, babatěk - zich uitrekken. Voorts die van een onvolkomen meervoud, bv. bantu - helpen, babantu - behulpzaam zijn. Een werkwoord kan door reduplicatie o.a. van een substantief gevormd worden en heeft dan de beteekenis ,zich bezighouden met, hanteeren”, bv. běbědil - met een geweer (bědil) op jacht gaan, sasapu - aanvegen (intrans.), $s a p u$ - bezem, van een transitief : nitah - iemand bevelen, titah - bevel, ninitah - iemand bevelen uitdeelen.

Reduplicatie + -an vormt collectieve werkwoorden, van de vorige slechts hierin onderscheiden dat -an een meervoudig element toevoegt, bv. papanahan - met pijl en boog schieten, van panah - pijl en boog, voorts kan de beteekenis die van een nabootsing zijn, bv. wazvarungan - waroenkje spelen, van warung. Zoo ook bij substantieven, bv. gugunungan - kunstmatig heuveltje, van gunung - berg. 
Zelfstandige naamwoorden met reduplicatie zonder meer van substantieven gevormd kunnen beteekenen, ,iets wat niet is wat het grondwoord aangeeft maar daaraan doet denken", bv. lilingga - knop van een houten klots, van lingga - de phallus, voorwerp van vereering. Van het grondwoord van een werkwoord afgeleid is de beteekenis ,het voorwerp dat een eigenschap vertoont die ook in het werkwoord te vinden is", bv. kotjop - bijeentrekken, dicht doen, kokotjop - de voorhuid.

Bij substantieven van adjectieven afgeleid vindt men hetzelfde, bv. bodas - wit, bobodas - het wit van een ei.

Ten slotte kunnen zelfstandige naamwoorden, door reduplicatie van het grondwoord van een werkwoord afgeleid, instrumentale beteekenis hebben, bv. kesed - vegen, kekesed - voetenveger.

In het Dayaksch vormen herhaling en reduplicatie van adjectieven beiden diminutieven, bv. hai - groot, hahai - tamelijk groot; humong - dom, humonghumong - tamelijk dom. Herhaling van een werkwoord bewerkt hetzelfde, bv. batiroh - slapen, batirohtiroh - een weinig slapen.

Hardeland vermeldt hierbij dat de herhaling met diminutieve beteekenis als één woord uitgesproken wordt, die welke een meervoud aangeeft als twee woorden: gĭlăgīlă - een weinig dom, gila gila allen dom. Dit is dus als in Soendaasch en Makassaarsch en Boegineesch.

Herhaling van een werkwoord kan ook meervoudige en intensieve beteekenis hebben ${ }^{1}$ ).

Het Iloko kent tweëerlei vorm van reduplicatie, 1e. herhaling van de eerste + beginconsonant der tweede lettergreep, zij drukt bij substantieven een meervoud uit, bv. purak - dorp, purpurak - dorpen, bij adjectieven evenzoo, bv. dakel - groot, dakdakel - meervoud, bovendien kan de beteekenis een comparatief of superlatief zijn, zoo kan dakdakel ook ,de grootste” beteekenen. Op werkwoorden toegepast geeft deze reduplicatie een duratief aan, bv. aglako - verkoopen, aglaklako - verkoopen, handelen in. Deze vorming komt, hoewel zeldzaam, ook in andere Filippijnsche talen voor.

De herhaling der eerste lettergreep vormt duratieve werkwoorden en is met het vorige gelijk te stellen ${ }^{2}$ ).

1) Hardeland, Grammatik der Dajackschen Sprache, blz. 68. - Amsterdam 1858.

2) Harold Williams, Grammatische Skizze der Ilocano-Sprache, blz. 10 v.v, 
Dit zijn, in het kort, de beteekenissen die herhaling en reduplicatie van grondwoorden als grammatische figuren kunnen hebben. Voor bizonderheden moet naar de spraakkunsten verwezen worden.

$\mathrm{Nu}$ zijn, als gezegd, herhaling en reduplicatie ook middelen om van wortels grondwoorden te vormen. De vraag is, wat vinden wij van de geschetste werking van beiden in dit geval weder?

In de Filippijnsche talen is het gebruikelijk den wortel te herhalen; het Jav. geeft de voorkeur aan reduplicatie en heeft deze in ruime mate toegepast, het Soendaasch staat tusschen beiden in. Dit wil niet zeggen dat de Filippijnsche talen geen reduplicatie zouden kennen noch het Javaansch de herhaling, er is hier slechts sprake van een gradueel verschil. Maar er volgt toch uit dat tusschen beiden, op wortels toegepast, geen scherp onderscheid is te maken. Eenige voorbeelden mogen dit toelichten.

Tag. bukbuk - molm, mijt, Jav. bu buk, Soend. bu buk - molm, mijt. (Tb. w ukw uk, Tond. dialectisch w u w uk), wortel wuk (b u k).

Tag. k u p k u p - beschermen, beschutten, Jav. k u k u p - met beide handen bijeenstrijken, Soend. kukup - werpen over, uitspreiden over, wortel kup, bedekken, vgl. met verwanten wortel Soend. kö kö p - toedekken, met den arm omvangen.

Tag. namnam - smaak, Jav. n jamnjam - idem; voor den wortel, zie beneden blz. 317 .

Tag. t a ktak - kappen, slaan, schudden, Jav. t ět a k (met klankverzwakking) -- hakken (besnijden), afhakken, tět ěk - afhakken, afsnijden, Soend. töktök - hakken, afhakken, Day. ta tak, Tont. Tb. taktak.

Tag. butbut - uittrekken, uithalen, Jav. bubut - uittrekken; wortel b u t - trekken, Soend. t j a b u t - uitrukken, Jav. r a b u t - uittrekken, lichten, Bat. Mand. bu but - uittrekken, v. planten, but b u t - uittrekken, v. veeren, de onderscheiding is willekeurig en een voorbeeld van differentieering bij verschillend klankverloop.

Tag. t u g t u g, Bis. t u k t u k - kloppen, slaan, Jav. t u t u k - kloppen, tikken, Soend. toktok - kloppen, tikken, in den wortel t uk ligt de beteekenis ,tikken, kloppen”, Soend. t ug - u.b. vóór ,,iemand het hoofd afslaan"; wortels met tenuis en muta als slotconsonant zijn verwant, zie hiervoor deze Bijdragen dl. 102 blz. 81 v.v..

Tag. b a n g b a ng - kanaal, afvoerleiding, Soend. b a ba n g - wegloopen, vlieden, van een wortel bang, waarin de beteekenis ,zich 
snel verwijderen" ligt, cf. Soend. b a ba ng - wegloopen, zich naar elders begeven en niet terugkeeren.

Tag. dinding en ding ding - wand, Jav. ḍiṇ ḍing - scherm, schut, Soend. dingding - wand, de Javaansche vorm kan zoowel

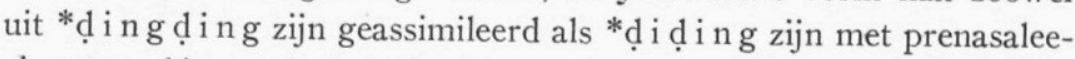
ring van ding; de beteekenis van den wortel is onzeker.

Tag. tiktik - spionneeren, op de loer liggen, Jav. titik - opsporen, Soend. titik - nauwkeurig onderzoeken; wortel onbekend.

Tag. luslus - loswinden, losmaken, Jav. 1olos - lostrekken, Soend. 1olos en roros - een wind laten, uitknijpen, wortel $1 \mathrm{os}$, in het Soend. u.b. bij ma ot - sterven, in dit - vertrekken.

Tag. siksik - tegen elkaar drukken, Jav. s ěs ěg - dicht op elkaar (zijn), Soend. s ĕs ěk - idem, opeendringen, Tb. sěk s ěk - dicht aan elkander.

Tag. bugbug - kapot stooten, beschadigen, wonden, Jav. bo brok - vervallen, bouwvallig, in puin, Soend. bokbrok - oud en vervallen, brok is een versterkte wortel van bok. Nagenoeg gelijkwaardig zijn bro, u.b. vóór: pöpös (breken, v. aardewerk), neerkomen v. e. fluim, tö d a mang (ziek worden, instorten), bru, u.b. vóór : vallen, brug, u.b. vóór : vallen, b u g, u.b. vóór : zich neerleggen om te slapen, buk - u.b. vóór: houwen. Bij de vorming van grondwoorden door herhaling en reduplicatie van een wortel wordt deze vaak versterkt, doch als regel alleen de wortel zelf.

Tag. dag d a g - vermeerderen, vergrooten, Jav. d ja d ja g - ferm van houding, manhaftig, Soend. d j a g d j a g - (weder) krachtig, gezond; de wortel is d j a g - overeind, cf. Soend. t a n d jag - houding, variant is d j ĕg: a d j ĕg Jav. vast, onveranderlijk, Soend. recht overeind.

Tag. laglag - vallen, Soend. ragrag en rarag - idem, de wortel r a g beteekent ,vallen”, Soend. purag - vallen, Tag. h u log (wortel lug $=\mathrm{rug}$ ) - vallen.

Tag. kikil, Bis. kilkil - vijl, rasp, Jav. kikir - vijl, Soend. kikir - idem; het Tagalog toont hier reduplicatie, zoo ook Tag. bu bung - dakvorst, Jav, w u w ung - idem, Soend. w uw ung idem; in den wortel ligt de beteekenis ,schut”.

Tab. bibig - mond, Jav. bibir - de lippen, Soend. biwir idem; wortel onbekend.

Tag. ta ta 1 - spaander, splinter; Jav. Soend. idem; de beteekenis van den wortel wordt duidelijk uit $\mathrm{Tb}$. kětil + afschilferen.

Vergelijk nog: 
Jav. tjĕtjak (met klankverzwakking) - huishagedis, Soend.

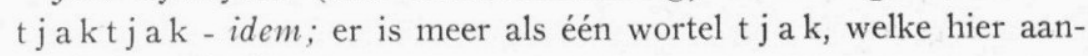
wezig is, valt niet te zeggen.

Jav. děděg - dicht opeen, v. menschen, Soend. dög dög - te hoop loopen.

Jav. djudjug - zich rechtstreeks ergens heen bewegen, Soend.

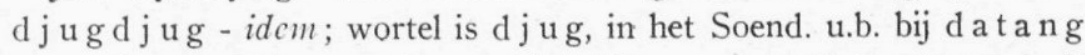
- aangekomen, dis u mpit - met het blaasroer geschoten, ka te joh - benedenwaarts (gevallen).

Soend. b ĕg b ĕg en b ĕ b ĕg - bekommerd, bezwaard.

Een zeldzaam voorbeeld dat het Jav. herhaalt, het Soend. redupliceert is Jav. kulkul - seinblok, Soend. kohkol, in geval van reduplicatie wordt vaak een $h$ ingeschoven, wat den vorm emphatischer maakt; er is een wortel kul die ,slaan met geraas maken" beteekent, Mal. Bat. Day. pukul - slaan, Tag. pukol - werpen, Soend. takol - op iets slaan, b.v. een gong.

Van alles wat herhaling en reduplicatie, op grondwoorden toegepast, teweeg kunnen brengen (waarvan boven een kort overzicht werd gegeven) blijkt bij deze herhaalde en geredupliceerde wortels niets. 't Is waar dat de herhaling of de reduplicatie een andere beteekenis dan den wortel hebben kunnen maar van een bepaalde werking is geen sprake. 't Eenige wat men er van zeggen kan is dat in het aldus gevormde grondwoord iets van de beteekenis van den wortel is terug te vinden maar vaste lijnen zijn niet te trekken.

Een zeer merkwaardig verschijnsel is het dat niet alleen zuivere wortels maar ook hun genasaleerde vormen dienen om er door herhaling of reduplicatie grondwoorden van te vormen.

Hierbeneden worden voorbeelden gegeven die dit kunnen toelichten. Uit den aard der zaak worden de wortels gegeven volgens de hedendaagsche uitspraak in de opgegeven taal. De grondtaal week daar van af. Er bestaat echter omtrent het klankstelsel dier grondtaal te veel onzekerheid om wortels in grondtaalvorm te kunnen reconstrueeren, nog daargelaten dat het woord ,grondtaal” gemakshalve gebezigd wordt voor een taal die uit verschillende dialecten bestond. Voor het doel hetwelk wij ons hier stellen, levert dit echter geen bezwaar op. Wanneer bv. naast elkaar gesteld worden: $\mathrm{muk}$ en buk, wil dit zeggen dat die wortel in de grondtaal welke thans in de vermelde taal $\mathrm{buk}$ luidt als genasaleerde vorm $\mathrm{muk}$ heeft. Hij kan buk of $w$ uk geweest zijn en bij dit laatste is dan nog tweëerlei 
uitspraak van de $w$ mogelijk, als de Nederlandsche of als de Engelsche $w$. Doch aangezien de beginconsonant van een zuiveren wortel nooit op een nasaal teruggaat, blijft de vergelijking: wortel met zuivere beginconsonant tegenover die met de homonyme nasaal beginnende, dus de genasaleerde wortel, haar waarde behouden.

't Is a priori niet te zeggen of een door herhaling of reduplicatie van een genasaleerden wortel gevormd grondwoord uit de grondtaal stamt of een product van latere ontwikkeling in één der talen welke van haar afstammen is. Wanneer men vindt van den wortel $\mathrm{dj}$ ĕng (blz. 318) Soend. d jööng, Png. nĕngnĕng, Mak. d j a nd ja ng, Boeg. $n j$ ĕnnjĕng, dan is het bestaan van beide vormen, t. w. grondwoord uit herhaling van den zuiveren wortel bestaande en grondwoord door herhaling van den genasaleerden wortel gevormd, waarschijnlijk; wanneer over het geheele taalgebied, met inbegrip van het Fidji, n a n a h - etter wordt gezegd, terwijl de wortel da h is (blz. 317), dan is het bestaan van den genasaleerden vorm in de grondtaal zeker; omgekeerd, wanneer het Tont. s ě's ĕ p - opzuigen, bezit, wat wijd verbreid is, maar daarnaast nog nĕ'nĕp, waarvan de afleiding $\mathrm{nu}$ m ĕn ěp een klein verschil in beteekenis met $\mathrm{s}$ ĕ $\mathrm{e} \mathrm{p}$ toont, dan moet de mogelijkheid worden aangenomen dat de genasaleerde vorm in het Tont. is ontstaan.

In het algemeen kan men dus zeggen dat de nasaleering van wortels in de grondtaal haar aanvang heeft genomen en in de loten welke van haar afstammen is voortgezet. Dit is ook wat men verwachten kon; waar het verschijnsel der genasaleerde wortels over het geheele taalgebied voorkomt, moet de oorsprong in de grondtaal gezocht worden. 't Komt mij - de verbreiding dezer vormen in aanmerking genomen - voor dat de meeste nasaleeringen op de grondtaal teruggaan.

De voorbeelden mogen thans volgen.

BAJ, MAJ. Soend. ma r a h ma j - stralen van genoegen, van het gelaat, gloren, met reduplicatie en versterkend infix - a r - gevormd van $\mathrm{ma} \mathrm{j}$; in geval van reduplicatie wordt in het Soend. tusschen reduplicator en wortel somtijds $h$ ingevoegd, wat den vorm emphatischer maakt; Soend. b a r a ba j - stralen, gloren, flikkeren.

BANG, MANG. O.Jav. mang mang - eed en vloek, Bat. Mand. eedsformulier, formuliergebed, Bat. Kar. formulier, eedformule, formule om bv. de gevolgen van een boozen droom te bezweren, N.Jav. ě b a ng - toezegging, belofte, b a ng b a n g - idem, in onbepaalden 
zin. „De algemeene zin van $\mathrm{mang} m$ ang en bangbang zal wel wezen ,luid roepen” (V. G. VI 301). Vgl. nog Boeg. m a m ě - voortdurend gegons eener menigte, ook van bissu-gezang gezegd.

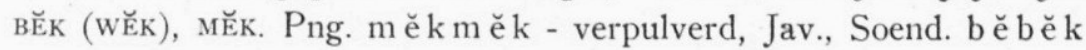
gw. - fijn stampen, Tont. w ĕ ' $\mathrm{m}$ b ĕk - stampen ${ }^{\mathbf{1}}$ ).

BĔNG, MĔNG. Soend. $m$ ělĕ $n g$ m ĕng - onduidelijk, als in een nevel, Tb. r i m bĕng b ĕng - donker ( $r$ i r i mběng b ěngěn - duizelen, duizelig), Tont. $\mathrm{r}$ i $\mathrm{m}$ b ě i m b ĕng - idem.

BIS, MIS. Soend. b i b is, Bis. b is b is - met water sprenkelen, Soend. biribis, sterke vorm van *bibis - motregen, Jav. grimis, Soend. girimis - motregen. - Soend. mimis - hagel (om mee te schieten) behoort bij wortel $\mathrm{w}$ is, zie hier achter.

I во, мо. Tag. $\mathrm{m} \mathrm{u} \mathrm{m} \mathrm{o} \mathrm{-} \mathrm{kleine} \mathrm{kruimels,} \mathrm{kleine} \mathrm{beetjes,} \mathrm{Png.} \mathrm{stomp,}$ v. d. tanden v. e. zaag, Pmp. m u m u - kleine deeltjes brood, zaagsel, stof enz., Tb. Jav. bobo - vermolmd, maar Tb. riw uw u molmig, mo o mo - rijstkruimels. In de Filippijnsche talen worden $\mu$ en $o$ aanhoudend verward, 't $\mathrm{Tb}$. onderscheidt beide klanken, doch hier loopen zij door elkaar.

II во, мо. Bis. $\mathrm{m}$ ù $\mathrm{m}$ ò - zijn gezicht tegen den grond stooten, Soend. b r o, b r u, versterkte wortels met beteekenis ,,neerkomen op, vallen op", Soend. t a m b r u - nederploffen.

III во, мо. O.Jav. m o m o - dwaas, Sang. idem, onnoozele, gebruikt door een moeder tot haar kind, z.v.a. jongenlief, i momo, z.v.a. 't jongske (door een ouderen broeder v. e. jongeren gezegd), Mangarewan $\mathrm{m} \mathrm{u} \mathrm{mu}$ - een dwaas (Tregear), Tag. bo b o - paljas, Bis. idem, lievelingsnaampje voor vrouwen.

BUK (WUk), MUK. Bat. Mand. mu muk - molm, Bat. Kar. half vermolmd, v. hout, Ilk. muk mók - restjes, Tag. bukbuk - mijt, molm, Jav. b u b uk - idem, Bis. b u k bok - idem, verpulveren ${ }^{2}$ ), Bkl. bok bok - houtmolm, Tb. w u kw u k - verrotten, v. hout of bamboe; Khm. buk - verrot (hout).

BUNG, MUNG. Mak. m u ' $\mathrm{mu}$ n g - stug, Bar. $\mathrm{m} \mathrm{u} \mathrm{mu} \mathrm{-} \mathrm{stil} \mathrm{zwijgend,}$ niet meedoende aan vroolijkheid, van een wortel b u $\mathrm{ng}$, $\mathrm{cf}$. Soend. ĕ m bung - het vertikken; een herhaling of reduplicatie van den zuiveren wortel in deze beteekenis is mij niet bekend.

1) Hoogstwaarschijnlijk behoort hier ook toe Ilk. mekmék - fijnheid v. verpoederd materiaal, verpulveren. In de orthographie van het Iloko wordt geen onderscheid gemaakt tusschen $e$ en $\breve{e}$, maar de pěpět komt vóór gutturalen (en nog in andere gevallen) voor.

${ }^{2}$ ) In het Bis. is $o$ de representant van de pěpĕt, buk en běk worden dus eensluidend, cf. BӖK, MӖK. 
BUR, mur. Bat. Tob. burbur - aanslibben, Bat. Mand. mumur . aanslibbing, aangeslibd zand.

But, Mut. Bat. Mand. mum ut - oud, versleten, Mal. bubut (Wb. s.v. mubut, dat de actieve vorm is, $m \mathrm{e}-$ is afgevallen, wat in het Maleisch zelden voorkomt) en $\mathrm{mumut}$ - verlegen, v. papier bv., licht breekbaar.

DAH, NAH. Austron. na nah - etter, Soend. budah - schuim, bobbel (op kokend water), Jav. bẹ̆ a h - opengebroken, doorbroken, Soend. s ĕn d a h - baar, Mal. $1 \mathrm{udah}$ - speeksel. Van verwanten wortel: Jav. duduh - uitgeperst sap, v. vruchten (met dentale d! de verandering is misschien uit differentieering met $\underset{d}{d} \mathrm{u} d \mathrm{uh}$ - omkappen v. rijststroo, te verklaren); Soend. $\mathrm{ud} \mathrm{u} \mathrm{h} \mathrm{-} \mathrm{week,} \mathrm{papperig,}$ t jiduh Jav. idu, id o h - zeever; Bat. Mand. sidada - puistjes op het gelaat; Sas. dadah - dun vloeibaar (v. lijm). Cf. Khm. khdu ḷ - etter, Bahn. dak - duh, St. tōh.

DAM, NAM (DJAM, NJAM). Tag., Bis. n a m n a m - smaak, proeven, Ilk. $\mathrm{n}$ a n a m - smaak, $\mathrm{n}$ a m n a m - proeven, Ibg. $\mathrm{n}$ a n $\mathrm{n}$ a m (uit $\mathrm{na}$ mn a m) - goed smaken. Tont. n a n a m - smaak, lekker van smakk, Bat. Kar. nanam - smaak, Bat. Mand. proeven, Jav. n jam $\mathrm{n}$ j a m ĕ n - de smaak v. iets in den mond beet hebben, Mal. $\mathrm{na}$ m $\mathrm{n} \mathrm{am}$ - een vruchtboom, voor $\mathrm{njamnjam}$, in het Mal. wisselen $n$ en $n j$ aan het begin van een woord, Tag. da m dam - gevoel, ook v. pijn.

. DANG, NANG; DING, NING. Soend. Jav. n a n g n ing - muzikale klanken, Soend. da ng ding - idem, melodie; Soend. n a n $\mathrm{n}$ a $\mathrm{ng}$ - geluid v. e. bel.

DENG, NENG. Soend. Jav. n e n g, ook: n e n g n e n g - muzikale klank, Tb. deng deng - klinken (met bepaalden klank).

DĔNG, NĔNG. Tb. nĕng nĕng - suizen, blazen, dĕng děng - dof klinken.

DUNG, NUNG; DONG, NONG. Jav. ḍ ung, ḍ ong, ook herhaald, klanknabootsing der eindvocalen van pada's, Jav. d ung d ung - Turksche trom, nung, no ng - klanknabootsing van het geluid van de gamĕlan, nongnong gung - idem. Vgl. nog Soend. madungdungkön - „dung, dung!” slaan op de kĕndang. DĔR, NĔR. Soend. nöhn ö r - bol, rond, de wortel is děr (dör), aanwezig in Soend. bunděr - rond, buděr en bu dör - rond omheen, omtrek, id ěr - rondgaan.

DIS, NIS. Tag. nisnís - versleten, ontrafeld, afwrijven, Bis. nis nis - schoon door afvegen, wrijven, Ilk. nisnís - keukenlap, 
Png. nisnis - borstel, Jav. ḍidis - naar ongedierte zoeken, bl i n ḍ is - geheel kaal, naakt, geplunderd, Soend. 1 ĕd is - geheel op, Tb. pĕdis - verslinden.

I DJAK, NJAK. Bat. Mand. $\mathrm{njaknjak}$ - overal bekend, Jav. $\mathrm{dja}$ $\mathrm{mak}$ (met infix - a m-, zie boven blz. 296) - algémeen, gemeenlijk, sadjak - iemands eigen manier v. iets te doen, dus: zijn gewoonte, zooals algemeen van hem bekend is, Mal. s ědjak sedert, sinds (het moment van bekend worden, het moment van gebeuren).

II DJAK, NJAK. Day. njanjak - vroolijk zijn, v. velen. (In het Dayaksch vertoont de geredupliceerde vorm wel eens meervoudige beteekenis), handjak - vroolijk zijn, wortel $\mathrm{djak}$. Misschien is hiertoe ook te rekenen: Bat. Mand. djakdjak - een klaterend geluid maken, v. water.

DJEN, NJEN. Mal. manjenjen - hoonen, smaden, het woord is $n$ j e n j e n, als gw. opgevat en van een prefix voorzien, Bat. Mand. djeng - recalcitrant, twistziek. Cf. Mon. kajān $(\mathrm{j}=\mathrm{dj})$ strijden, Khmer ǵ a ńg én - idem.

I DJĔNG, NJĔNG. Soend. $g$ ĕn $\mathrm{j}$ ĕ $n \mathrm{j}$ ĕng, u.b. vóór (aanpakken en meenemen), 1 ĕ nd j ĕng - recht omhoog gaan. De wortel d j ěng is een variant van djung - oprijzen en weggaan, Bat. Mand. d j ong d j ong - staande, opgericht.

II DJĔNG, NJĚng. Boeg. $\mathrm{nj}$ ĕnnjĕng - ergens naar staren, Mak. d j a nd j a ng - idem, Png. nĕng nĕng - zien, Soend. d jööng (met vocaalsplitsing) - zien.

DJĔP, NJĚP. Jav. n j ĕn j ěp - stil, eenzaam, Oud-Jav. n j ěpn jĕp behoorlijk, d j ĕdj ĕp - stil. De wortel dje ěp is in het Soend. u.b. vóór : repeh - zweeg, d jĕmpe - stil, enz..

DJĔT, NJ̌̌t. Jav. n j ě n j ĕt - doodsch, koud, kil op het gevoel, bv. v. e. lijk; Jav. djĕdjĕt - kil, ijskoud v. h. lichaam bij betasting. DJIP, NJIP. Oud-Jav. njipnjip - stil, Mad. djidjíp - in orde, juist.

DJOH, NJoH. Soend. njahnjah njohnjoh - schrokkende uit de linker-en rechterhand tegelijk happen, Soend. $\mathrm{djodjoh} \mathrm{-} \mathrm{iets}$ sterk, met kracht, met grooten lust of ijver doen, Mal. g a 1 o d j o h - gulzig, met meervoud - infix -a 1-.

Dјот, Nјот. Mal. n j on jot - rekken, v. leder, touw e. d. Vermoedelijk behoort Bat. Mand. n j o n j o t - brandende pijn doen, bv: bijensteken, hier ook toe en heeft men aan door de pijn veroorzaakte trekkingen door het lichaam te denken, Soend. kě djjot - plotse- 
ling een gedachte krijgen of een begeerte om iets te doen, k u m ĕ d j o t - ontstellen, Mal. kĕd jut - schok van het lichaam, schrik, Soend. $g$ ĕn d jot - een snellen ruk a. iets doen, een snellen duw a. iets geven, Day. d j u d j u t - wurgen met een strik, Jav. uitrekken, langer maken, ruwe katoen uitrekken, Day. ka j j u - plotseling afgeloopen, van het water.

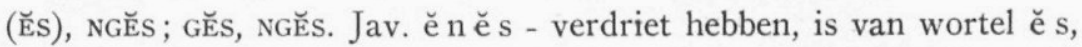
O.Jav. ng ěsng ěs - neerslachtig zijn, zie boven blz. 298. Verwant is wortel gěs, waarvan Jav. ěng ĕs - aandoenlijk, g ĕg ĕs - verkwijnen. Zie nog gas, ngas.

GaL, NGaL. Ilk. ng a lng á 1 - kauwen, Png. ng a $\operatorname{lng}$ a 1 - op iets hards bijten, Ibg. ng a ng ng a 1 - kauwen, Gaj. ng ĕng a 1 - idem, Ilk. galgál = ngalngal, Png. galgál - kauwen, Mgd. galgál idem. Vgl. Soend. g e g e 1 - bijten.

GAP, NGAP; HAP, NGAP. Mal. n g a p en ng a p n g a p - naar adem snakken, Soend. $m$ ĕg a p m ěg a p - hijgen, Jav. ěg a p - naar adem hijgen.

Mal. ngĕng a p - naar adem snakken, Soend. önga p en öngh a p - benauwd op de borst, Soend. měng hap $\mathrm{mĕn} g$ ha p en $\mathrm{m}$ ĕng a p m ĕng a p hijgen, Kkmer ha p - buiten adem.

GAR, NGAR. Bat. Kar. nga rngar - ratelen, als een bord met een barst, Mak. ng a ngar a' - schreeuwen, hard praten, Bis. ng a 1 ng a 1 - kletsen, Tag. ng a ln gá 1 - schreeuwen, Tont. ng a' ng a 1 - gesteun, Mao. ng ang a - lawaai maken, Haw. n a na - huilen, snauwen, Mlg. nan a - hard roepen, Mak. g a' g a r a' - [1. gagara'?] - zoo spreken dat het ergen indruk maakt, hard aanspreken, toesnauwen, Boeg. g a g a', m a n g k a g a' - twisten, a n g k a ga r 1 , ma ng k a ga ri - krakeelen over.

GER, NGER. Maori ng e n ge re - geraas maken, ng e n ge ri - grommen, grunniken, Mal. g e ge r - geraas, tieren. De slot $e$ in Maori is steunvocaal, evenals $-u$ in het volgende geval.

GUR, NGUR. Maori ng u n g u r u - geraas, geruisch, Soend. g u g u r geruisch, geklater, donder.

GĔR, NGĔR. Bat. Kar. n g ĕr n g ĕ r - eeuwig lang op iemand moeten wachten, Jav. g ěg ěr - staan blijven, stand houden, a n g g ĕ r . paal die dient om iets vast te zetten, wetsbepaling, Soend. a ng g ĕr - op dezelfde hoogte blijven, bestendig. Cf. Jav. tugur doorblijven op zijn post.

Gas, NGAS. Bat. Mand. ng a sng a sa n - ongeduldig worden, Soend. 
g a gas - ontroeren, pug a s - hevig aangedaan; Jav. angas weifelen, wankelen, v. moed.

I GAT, NGAT. Tag. ng a tn gá t - kauwen, Bat. Mand. ng a t ng a t - op iets rauws knabbelen, Day. g a g a t - mot.

GAK, NGAK. O.Jav. ngak - klanknabootsend geluid v. (rollende) wagens, N.Jav. klanknabootsing geluid vogel t jangak, ngak$\mathrm{ng}$ a k - snateren, Bkl. n g a kn g a k - een groote roofvogel (naar het geluid dat hij maakt), Png. geluid v. d. karbouw, Tag. g a k gá k - praatachtig(heid), Ilk., Pmp., Png. ga k gák - gekwaak v. kikvorschen, soort eend.

GEK, NGEK. Jav. e n g e k - een muzikaal geluid geven, v. zingenden, v. e. viool enz., Soend. n g e k, u.b. vóór : t a r o m p e t - daar klonk de trompet, Soend. ng okngek - geluid v. d. r ĕ ba b en v. d. tarawangsa, Tb. ngekngek - kraamvrouwenvampyr (ongetwijfeld naar het geluid dat hij maakt), Jav. g e g e k - oprispingen hebben $\mathrm{P}$., rochelend geluid als v. e. stervende.

GIK, NGIK. Jav. in g i k - een muzikaal geluid geven, v. zingenden, v. e. viool, Ilk. Png. gi k gík - een kleine (nacht)vogel, wel zoo genoemd naar het geluid dat hij maakt, dit geldt ook van Pmp. g i k gik - rillen van de koude, doch Tag. gikgik - knorren (of schreeuwen?) v. e. speenvarken, knarsen v. e. deur.

GOK, NGOK. Soend. ngok, u.b. vóór: dit j i jum - gekust, Soend. golokgok - geluid v. water dat uit een flesch gegoten wordt of daarin loopt, klokken, geluid v. braken (sterke vorm van * gokgok).

GUK, NGUK. Bat. Mand. ngu kng u k - snikken, Soend. ng a kn g a k - n g u k n g u k - onsamenhangende klanken uitstooten, Day. n g o k - geluid van snikken, Jav. g u g u k - stuipachtig snikken, van een schreiende, Soend. g u kg uk - snikken.

GĔK; NGĔK. Bat. Mand. n g o k - niet in te slikken, Jav. g ĕ k, g ĕ g ě k - klanknabootsing v. drinken, g ĕ k g ĕ k - klok, klok, P..

GĔNG, NGĔNG. Bat. Kar. g ĕn g g ĕ n g - geduldig, iets lang verdragen, Bat. Mand. ng ong ong - ledig, zonder bezigheid zijnde, maar Jav. ěng g ĕng - ergens zijn of staan blijven zonder aangeroerd of gebruikt te worden.

II GAT, NGAT. Bis. Hil. ngatngat - iemands mond met geweld openen, Bis. Sam. Ley. idem - vergrooten, Bkl. idem - het breken van de ram van een schip, doch Png. idem - twisten zonder tot slagen over te gaan, Bat. Karo g a t g a t - fijn hakken (n g g a t g a t), fijn tjangkollen (ĕ rg a tg a t), term bij de veldbewerking. — Ik vermoed dat 
Tag., Pmp. ng a t ngát - knagen, ook op een zuiveren wortel gat teruggaan, cf. g i t, g ět, g u t (bij k u t), doch of dit dezelfde wortel is, lijkt onzeker.

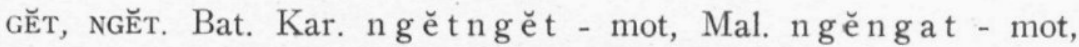
Soend. g ěg ět - knaagmijt, Mal. g ěg a t - mot.

GIT, NGIT. Bat. Mand. ngitngit - kleermot, Mal. gigit - bijten.

Ilk. ng et ng ét - doorsnijden met de tanden.

HA, NGA; HANG, NGang. Mal., Day., Mak., Boeg., Tont. nganga - open v. d. mond, v. e. deur, Soend. ng a n g a h (met emphatische $h$ ) open, gapende, uiteenstaan, als de punten v. e. pen, Bar. ng a ng a - binnenmond, mondholte, stem, Bat. Kar. ng a n g a - wijd openstaạn, v. d. mond, met open mond, Tag., Bis. n g a n g a - geopend, v. d. mond. - Bat. Mand. toont den gesloten vorm: ng a n g a n g - openstaande (mond of deur), mond (grof), evenzoo Soend. bu $\mathrm{n} g$ a n g a n $\mathrm{g}$ - wijd open, b u h a ha n $\mathrm{g}$ - groot, diep, bv. een scheur of wond. De zuivere wortel is dus ha, ha ng, wat bevestigd wordt door Mon, Bahn., St. ha, Khm. hã - den mond openen, het Wb. van Halliday geeft voor Mon hā - openen, gapen v. e. wond, hã pa in - den mond openen.

нав, NGAB. Atj. ng a bngab - begeerig, inhalig, Soend. ha lab hab - (= habhab met infix - al-) dorst hebbende, dorstig, Bar. hoho - inhalig. Cf. Gaj. mĕng a p - vraatzuchtig, gulzig, inhalig.

HAH, NGAH. Mal. ng a hng a h - hijgen v. vermoeienis, Day. ng a ng ä h - stenen, Soend. h u h ha h - hijgen; ha h geeft den klank aan dien men uitstoot als men hijgt, maar ook als men zijn instemming met het gezegde betuigt (grof), vandaar de beteekenis van $\mathrm{h} u \mathrm{hhah}$ als antwoord op vragen steeds maar ,hah” (ja) zeggen.

HANG, NGANG. Bat. Kar. n g a n g n g a n g - boos zijn, twisten, Soend. haringhang (met infix - ar -) - onaangenaam aangedaan, geprikkeld v. humeur.

HEK, NGEK; HOK, NGOK; HUK, NGUK; HĔK, NGĔK. Tont. ng o k - nabootsing geschreeuw apen, ng e k n g o k-idem, Soend. n g u k - idem, ng ĕk - idem, Bis. ha lukhuk - soort muskiet, Jav. t j ĕng u k jonge aap, naar het geluid dat hij maakt, Soend. hok hoka n geluid v. d. pauw, h u k he k - hijgen en stooten van de ademhaling, hakhikhěk - nabootsing geluid apen, hěk - uitroep, i. c. bij het trappen op een slang, huk hak hokhok - jammergeluiden uitstooten, v. e. weeklagende, Day. hak, he k - zich de keel schrapen,

D1. 102. 
bv. wanneer iets in de keel vastzit, hak hak of hok hek - een keelgeluid maken, als iemand iets in de keel vastzit.

HĔL, NGĔL. Bat. Mand. n golngol - zich vervelen, vinden dat iets lang duurt. Wortel is h ěl (höl) blijkens Soend. köhöl - kregel, iets moede zijn, 't verveelt (mij) om het nog langer te doen.

HENG, NGENG. Atj. ngengngeng $=$ hengheng - gonzen. нIH, NGIH. Bat. Kar. ng i hn g i h, d ĕ n g e h dĕ ng i h - hinneken, Jav. banging i h, bang ingeh-idem, Bar. bih i hi, idem.

HING, NGING. Soend. ng ing, u.b. vóór: t j örik - schreien, hing idem. Cf. Tag. haling hing - weeklacht.

кав, NGAB. Tag. ngabng a b, Pamp. ng a bngab-bijten, Bis. Seb. en Bkl. ngabngab - nonsens praten, Bis. Hil. klagen, schreeuwen, Ilk. ng a b ng áb - mond v. e. vat of gat, Bis. Sam. Ley. ngabngab - den mond openen, Pang. verwijding v. e. wond, Soend. k a k a b - een stuk in j j k zooals het in zijn geheel v. d. arenpalmstam komt (dezen omsluitende), Jav. u $\mathrm{ng} \mathrm{k} \mathrm{a} \mathrm{b} \mathrm{-} \mathrm{opening,}$ opengaan v. iets dat met een deksel gesloten is, Soend. si n g kab, Jav. ě n g k a b - opengeslagen, opengezet, ě ng k a b - ĕn g k a b a n - luik, klep. Wortel is $\mathrm{kab}$. Er is een wortel k ěb $=\mathrm{k}$ ĕ p, k ĕ m met varieteiten, waarin de beteekenis ,gesloten, op elkander" ligt. Van deze toont $\mathrm{k} \mathrm{a} \mathrm{b}$ een eigenaardige ontwikkeling in zooverre dat de grondbeteekenis wel aanwezig is maar daaraan is verbonden het open en dicht gaan; het opengaan van iets dat dicht kan of behoort te zijn, het ontsluiten.

KAR, NGAR. Bat. Mand. ng a rnga r - scherf, Boeg. ta'ba li ka'ka' - v. bergen, onderste boven gekeerd en opgebroken. Cf. Jav. ta $1 \mathrm{a}$ w e n g ka r - scherf, Jav. bo ng kar - opbreken, Soend. d ung $\mathrm{ka} \mathrm{r}$ - uit den grond breken.

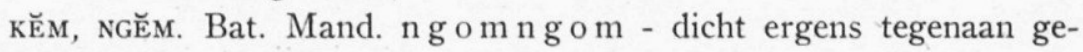
drukt, Jav. k ĕ k ěm - iets, zooals de vingers tot een vuist, samentrekken, Bat. Kar. kĕm k ĕm - geheel insluiten, als bergen een vlakte.

KӖP, NGĔP. Bat. Mand. ng o p n g op - iets stevig vasthouden door het tegen zich aan te drukken, Jav. k ĕk ĕ p - omvatten, in de armen houden. De wortel k ĕp is gelijkwaardig met den vorigen, $\mathrm{k}$ ĕm.

KĚs; NGĔS. Bat. Mand. ng os ng os - ergens dicht tegenaan, stevig aangetrokken, h o s k o s - stijf toegebonden, stijf aangetrokken, $\mathrm{Tb}$. k ĕ s k ěs - bundelen, inwikkelen.

I KIS, NGIS. Tb. rang is ng is - krassen, schuifelen, ritselen (doch 
ri kaska s - ritselen, v. dorre bladeren enz.), Tont. ng i'ng is schoonwrijven, poetsen, Tb. kiskis - afkrabben, afscheren; Tont. k i'ki s - vijl, Tont. ra ng k i' ki s - krassend geluid (twee stukken bamboe tegen elkaar, een griffel op de lei).

II KIS, NGIS. Tag. ng is $\mathrm{ng}$ is - knarsetanden, Bis. $\mathrm{ng}$ is $\mathrm{ng}$ is en $\mathrm{n} g$ is i - de tanden toonen (- $\mathrm{i}$ is hier een oud suffix $=-\mathrm{a} n)$, Pmp. $\mathrm{ng}$ i s ngis en $\mathrm{ng}$ is i - beweging van den mond als van een kind dat wil gaan schreien, een hond die wil gaan bijten, Mak. ki'ki' kauwen, Mad. keke(h) - met den snavel pikken, Soend. kekes - eekhoorn; Tag. ng is ng is vormt een overgang tot de beteekenis van kis I; ' $t$ is mogelijk dat de wortels $\mathrm{k}$ is I en kis II in den grond één zijn.

KIT (GIT), NGIT; KUt (GUT), NGUt. Mal. ng u $\mathrm{n}$ g it - het geluid v. e. viool die gestemd wordt, een houtwurm, onnutte praatjes maken, Mal. ngutngut - leuteren, sammelen, talmen, O.Jav. gutgut ĕn - knarsetanden, Bkl. ng u tng u t - knagen, Tb. kutkut knabbelen, rangutngut - kraken, knarsen, Tont. rangku' $\mathrm{kut}$ - geluid ontstaan door de beweging der ledematen, Soend. ungkut-ungkut - naam v. e. vogel, naar zijn geluid, rek ot - kraken, Tb. rik o tk ot - gekrabbel, geknabbel, knabbelen, Tont. rangko'kot - geluid v. h. gekrabbel v. e. kat, hond, rat, enz. $\mathrm{Kut}$ en $\mathrm{g}$ ut zijn twee uitspraken van een zelfden wortel. Day. $\mathrm{nget}$, ngit - geluid dat een hommel in een gat in een boom maakt, is van get, git, want $\mathrm{g}$ a gat is mot. Waarschijnlijk is Mal. ngutngit ook van een wortel git en het woord een herhaling met klinkerverandering van ngit, doch wegens Mal. d ĕkut - kirren, koeren, is dit niet geheel zeker. Tb. en Tont. hebben wel eens meer $k$ waar het Mal. $g$ heeft. Png. gitg it - knarsetanden. Er is dus een wortel git, terwijl kit voorkomt in Soend. $\mathrm{t} \mathrm{j}$ ĕkit - piepen, als een ongesmeerd wiel.

KUL, NGUL. Bkl. ng u ln g u 1 - geschreeuw, beweenen v. dooden; Jav. Bal. kulkul - signaalblok. Cf. Tont. ta kul, blz. 287. KOD, NGOD. Tag., Png., Pmp. ng u dng od - op zijn gezicht vallen. In den wortel $\mathrm{k}$ od en varianten ligt de beteekenis ,tegen iets aan, contact hebbende", Soend. kok od - hand (grof), ta ngk od zich vastklemmen.

KoK, NGOK. Boeg. ng o'ng o' - kraaien, v. e. haan, Jav. kok o k geklok, v. hanen en hennen, Soend. k on gk or on g o k - kraaien, v. e. haan, Tb. pĕk ok - kakelen.

Kos, NGos. Tag. ngu sngós - bek, snoet, Bis. Hil. ngusngus, 
Png ngusngos - caresseeren door een hond van zijn meester (d.w.z. zijn snuit tegen hem aan drukken), Bis. Sam. Ley. ngos $\mathrm{ng}$ o s - tegen zijn meester opspringen, v. e. hond (als voren), Pmp. ngusngus - kauwen, Soend. kokos - in den bek nemen (ngokos), aan iets knabbelen (ngokosan - lett. met den bek ergens aan zitten), Mak. ko'ko' - kauwen, Ibg. ngang ng ot ( $t$ is representant van $s$ in de zustertalen), Tb. ng a ngo; Bkl. ngosngós - met v. woede geopenden mond, v. iemand die boos is gezegd, gehuil v. e. hond.

PaH, мaн. Mal., Jav. mamah - kauwen, Tag., Ibg. ma má, Bis., Sang. $\mathrm{ma}$ a - idem, Bat. Mand. ma ma - een zuigeling gekauwde rijst te eten geven, Bat. Kar. $\mathrm{mam}$ a h - voederen, als vogels hun jongen, Mad. pa p pa h - pruim, Soend. söpah - sirih kauwen, Boes. s épa' - sirih kauwen en kauwen in het algemeen.

PAK, МАK; ВАK (WАK), МАK. Bat. Mand. ba $\mathrm{u}$ mamak, groote brokken steen, eig. aan stukken geslagen steen, Bis. Bik. makmakslaan, Jav. p a p a k - vlak af, plat (geslagen), Mal. k ĕ p a k - vleugel, gew. v. klapwieken, de naam ziet dus op het klappen met de vleugels, hierbij is wel in de eerste plaats aan het hoen te denken, Soend. k a pa k - de vleugels uitslaan, met de vleugels ergens tegenaan slaan; Tb. wakwak - kapot smakken, Bis. bakbak blaren v. e. boom afnemen (kappen), Bkl., Tag. bakbak - ontschorsen (d.w.z. door kloppen), Jav. babakan - boomschors, nieuwe ontginning d.w.z. een opengekapte plaats, een lichting, in het bosch, Jav. bakbak - met de vlerken slaan, v. e. haan (het Wb. noemt dit een klanknabootsing). De wortels pak en bak zijn gelijkwaardig, Bat. $\mathrm{mamak}$ is zeker van wortel $\mathrm{pak}$, vgl. Soend. bat u pek prek - steenslag, Bat. Kar. pĕkpěk - slaan, pikpik - tikken, pukpuk - grof stampen, Bis., Bkl. makmak kan van beiden zijn.

PANG, MANG. Bis. man $\mathrm{g} \mathrm{man} g$ - koperen bel; muntstuk v. 1 peso, Soend. ba pang - metalen plaat, Jav. tampang - stukjes lood onder aan een vischnet, ook: rol (tabak), Soend. kupan $\mathrm{g}$ - dubbeltje, Tont. kupang - woekerplant met kleine, ronde bladeren. Soend. empang - schoteltje. De beteekenis van dezen wortel pang (er zijn er meer) is ,rond”.

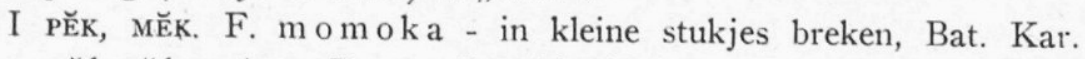
p ĕkpĕk - slaan, Boeg. pěp p ě' - kloppen, slaan, Jav. r ěměk verbrijzeld.

II РӖK, мӗK. Jav. m ĕm ĕk en $m$ ĕmak - dik (donker glanzend) v. h. hoofdhaar, ook $=\mathrm{m}$ ĕ k m ĕ k . golvend, misschien vroeger weel- 
derig (v. d. T.), Jav. Soend. pĕp ěk - voltallig bijeen, Mal. p ĕ $\mathrm{pak}$ - het geheel.

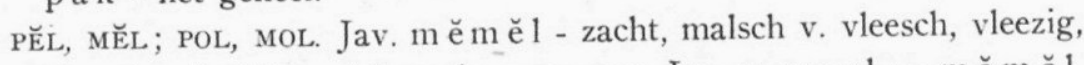
Soend. p ěpěl - vol korrels, v. e. aar; Jav. momol = mĕ m ĕl, ĕm pol; ě pol - het zachte, vleezige gedeelte der jonge kokosnoot bij de steel; popol- murw, week, malsch geworden.

I PĔS, MĔs. Tag. $\mathrm{m}$ is $\mathrm{m}$ is - vleesch en overblijfselen morsen, Tont. pĕ'pĕs - uitslaan, bv. goed waaruit men stof, zand, vuil of beestjes wil slaan, zaad strooien, Tb. pĕs p ĕs - zaad strooien.

II pĔs, MĚs. Png. měs měs - kneden, Tont. mĕ'mĕ $\mathrm{s}$ - iets knedend vatten zoodat het verkreukeld wordt, Jav. p ě pĕ s - kneuzen, kroken, Jav. r a m ěs - door elkander gemengd, a p ĕs - zwak, zonder weerstandsvermogen.

III PĔS, MĔs. Jav. mĕměs - aangenaam zacht, malsch v. groente, Jav. p ěpĕs - geknakt, slap erbij hangen, Soend. pĕs, u.b. vóór : dooven v. vuur, sterven, leeggeloopen rijwielband. Zelfde als II.

PES, MES. Jav. me mes - in pakjes v. blad roosteren, Jav. pe pe s a n - in pakjes v. blad geroosterde kost, ěpes - zoon pakje, Mak. kempe se' - slinken.

PIH, мiн. Soend. mahmahmihmih - schrokken, ĕmah ĕmih - al maar eten, lang eten, ěm $\mathrm{pah}$ ĕmpih - idem.

PIK, MIK. Tag. mikmik - weerstand, Bkl. iets waarop men, loopende, met den voet treedt, Bat. Kar. pik pik - tikken, even slaan, specerijen even kneuzen opdat de etherische olie voor den dag treedt, Soend. höm pik - iets neerdrukken door er wat op te leggen.

PIS, MIs. Mak. mi'mi s i' - zuigen, slobberen, Bar. mimi - sap van uitgezogen spijs in den mond spuwen, iets uitkauwen en in den mond spuwen, Jav. p ip i s - brei, pap, fijnwrijven met wrijfsteen, Day. $\mathrm{h}$ a $\mathrm{m}$ is - uitpersen, uitwringen, Soend. $\mathrm{k}$ a $\mathrm{m}$ p is - boom uit welks zaden men lampolie perst. In het Bare'e is de beteekenis uitgebreid en tevens gespecialiseerd.

PON, Mon. Bat. Mand. m o n m o n - snot, Tont. s ěpu n, Sang. s ĕ mung, Tag., Bis., Bik., Pamp. si pon.

PONG, MONG. Mal. mong mong - ketelinstrument behoorende bij de gamĕlan, ook voor omroepbekken gebruikt (Klinkert), v. R. geeft m ung m ung - klein koperen omroepbekken, Bat. Mand. mong mongan - klein muziekbekken, Oud-Jav. mongmong - bekken, Boeg. mongěng mongĕng - soort bekken, Soend. goong mongmong - soort gong, Soend. pong pong en pong prong - klinken, v. h. geluid v. e. gamelan-orkest. 
PU, MU. Ilk., Png. mumo - rauwe wonden in den mond door zware ziekte, Bat. Kar. p u pu - licht uitvallen, v. tanden, los zitten.

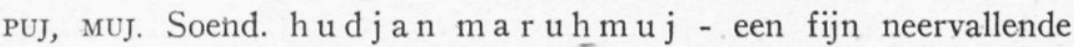
regen $=\mathrm{hudjan} \mathrm{ng} \mathrm{ĕpruj} \mathrm{-} \mathrm{stofregen,} \mathrm{k} \mathrm{ĕpruj,} \mathrm{versterkte}$ vorm van kĕpuj, is ook: mul, fijn, v. aarde of zand.

I PUK, MUK. Bis. $\mathrm{muk} \mathrm{mok}$ - slaan, Ilk. $\mathrm{m} \mathrm{u} \mathrm{kmók} \mathrm{-} \mathrm{kruimels,} \mathrm{over-}$ gelaten zaken, vgl. Tag. $\mathrm{mumo}$, sv. I bo, mo, Tont. pu'puk verbrijzeld, stuk, geheel kapot, Bat. Kar. pukp u k - grof stampen, Jav. Soend. r ĕmuk - verbrijzeld, vergruisd, Bat. Kar. ripuk aan gruizels.

II PUK, MUK. Tag. $\mathrm{mukmó} \mathrm{k}$, als beteekenissen worden opgegeven: zich bemoeien met, verbergen (Institute of National language), herhaaldelijk met elkaar als in het geheim spreken (de Noceda), met elkaar praten in een hoekje (Laktaw), dus: samenscholen, Bis. mukmuk - laken, verwijten, beschuldigen, berispen (Institute), openbare weg waarlangs veel menschen passeeren (de la Encarnacion), Png. mokmók - troepje menschen die een buurpraatje maken, Day. pupok - allen zijn gekomen, allen zijn verzameld, Jav. t u m p u k - stapel, kl u m p u k - bijeenzamelen.

I PUS, MUS. Ilk. musmós - goedkoope tabak, muntstuk met afgesleten beeldenaar, Bkl. mosmos - langzaam vervallend, Mal. pupus - geheel op, van goed of geld, afgestorven, v. planten, Jav. p u p u s - overleden, Bat. Mand. uitwisschen. Een andere betekenis is Tag. musmós - kind, onschuldig, eerlijk, Ilk. dom, Png. dom, onwetend; ik houd dit voor een anderen wortel.

II pUS, MUS. Bis. Seb. mus mos - iemands gezicht in woede over den grond wrijven, Bis. Sam. Ley. musmus - hevig, intens, Bkl. mosmos - verbrijzelen, gewoonlijk op iemands gezicht toegepast, Bkl. pospos - slaan, zweepen, met woede, Cf. Soend. pö pös breken, verbrijzelen, Jav. pěp ěs - geknakt.

I PUT, MUT. Bat. Mand. m u m u t - oud, versleten, Jav. puput - tot het einde, dood, Soend. uit, afgedaan.

II PUT, MUT. Soend. ma jut mut (aldus te lezen voor Wb. maj u$\mathrm{mut}$ ) - als met een wollige wade overdekt, zich wollig voordoen, Bis. potpot - slib door rivieren na een overstrooming op de oevers achtergelaten. Van een wortel put waarin de beteekenis „drukken, bedekken” ligt, vgl. Tjam sampot - sorte de pagne (Maspéro, Royaume de Champa p. 35 nt. 5), Boeg. sampu' sarong, overtrek, O.Jav. sa put - bedekking, Soend. su m put verbergen enz. Varieteit van wortel pit. 
$\mathrm{RAB}, \mathrm{NAB}$. Bat. Mand. $\mathrm{n}$ a n a $\mathrm{p}$ - in menigte iets bedekken, geheel bedekt, O.Jav. rarab-dalen, vallen, Soend. $r a r a b$ in kara ra ban, bv. sapowe djĕput hĕntö kararaban sangu saremoh - den ganschen dag is mij geen kruimel rijst toegevallen, d.i. heb ik nog geen rijst gegeten. Van $r$ bestaat geen nasaleering (waarover nader in hoofdstuk V), $n$ is nasaleering van $d$, de uitspraak van den wortel moet dus in den grondtaal (of in die gouwspraak waarvan $\mathrm{nab}$ afkomt), $\mathrm{d}$ a b geweest zijn (met palatale $d$ ). Bekend is dat $d$ en $r$ in de zelfde taal wisselen, Jav. $r$ a t u maar kaḍaton naast karaton, Jav. da anghyang - schutsgeest, Soend. parahijangan - de Preanger, het verblijf der rahi $\mathrm{j}$ a ng - geesten. Waarschijnlijk bestond deze wisseling reeds in de grondtaal, vgl. nog Tag. tu nd uk $=\mathrm{turuk}$ - steken, als met een naald; de wijdverbreide wortel $\mathrm{d} u \mathrm{k}$ gaat zeker op de grondtaal terug; daar $d$ en $r$ in het midden van een woord in het Tag. niet wisselen, moet $\mathrm{ruk}$ ook uit de grondtaal zijn meegenomen.

кӖв, ㄷ̆в. Soend. nĕn ĕ b - afkoelen, overnachten, zich naar een koele plek begeven om uit te blazen, Soend. r ĕ r ĕb - rust houden onder weg om als het dag is, de koelte van den avond, als het nacht is, het opkomen van de maan of het daglicht, in het algemeen de een of andere omstandigheid af te wachten, aan den tocht bevorderlijk om dan weer op stap te gaan, overnachten ${ }^{1}$ ), Jav. 1 ěr ě b, $\mathrm{r}$ ĕr ě b - ergens rust houden, K.I. overnachten, 1 ĕ rě b is dissimilatie van rĕrĕb. Zelfde geval als voren. Synoniem is Soend. nonob, ongetwijfeld teruggaande op een zuiveren wortel rob, die mij niet bekend is.

RIH, NIH. Bat. Kar. nihnih - in termijnen, bij beetjes af doen (ĕr nihnih), rihrih = ĕrnihnih, ngĕririh - telkens een beetje in de kookpot doen.

SAJ, NAJ. Soend. nahna j - moede, uitgeput, afgemat; sa saj - afgemat, Mal. manai en putjat manai - bleekwit, cf. Soend. luse en lungse - afgemat. In het Soend. beantwoordt aan den tweeklank a i beurtelings a j en e, bv. gaw e - werk, Mal. ga wa i, s a mpaj - hangen over (een lijn of stok), Mal. sampai; beide vormen van één woord in: b a ngke - lijk, kreng, s a wan b a n g ka j - stuipen krijgen van wege een lijk (nl. der overleden moeder), Mal. bangkai.

SANG, NANG; SING, NING. Soend. $\mathrm{n}$ in $\mathrm{g} n$ a $\mathrm{n} g$ - ongelijk, bv. v. grootte,

1) Wb. Oosting s.v., Coolsma is onvolledig en minder juist. 
niet bij elkaar passend, Soend. sing - ieder, iedereen, elk afzonderlijk, Jav. Soend. s a n g, bijvorm v. één, gesloten vorm naast het pers. lidw. si en relativum.

SAP, NAP. Bat. Kar. na p n a p - geheel verdelgd, weggevaagd ${ }^{1}$ ), Tag. s a p s a p - schillen, Bis. hout van de bast ontdoen, Soend. s a s a p - met den grond gelijk maken, bij den grond afslaan, gelijk of vlak maken.

SAR, NAR. Mal. n a n a r - verward, zinneloos, Soend. s a s a r - dwalen, ronddwalen, niet wel bij het hoofd zijn, Jav. geheel van de wijs, verkeerd.

SĔP, NĔP. Tont. ně'nĕp - bedorven palmwijn, doch num ě'nĕp bij zeer kleine beetjes eenig vocht opzuigen en inslikken, Tb. n ĕpn ě p - doorslikken, inslikken, Tont. s ě's ěp - opzuigen.

SOR, Nor. Bat. Mand. nornor - goed bevloeid, vol v. water, Tont. so'so' - vloeien, Soend. sor u.b., bv. sor, sor, tja ian - ga voort er water op te gieten.

Sот, кот. Tag. nut not - gerafeld, versleten, ook: de riemen losser maken, Bis. Hil. n ot n ot - idem, Jav. s ot - los, vrij, Soend. u.b. van loslaten.

$\mathrm{su}$, NU. Indon. susu - vrouwenborst, Mlg. $\mathrm{nunu}$ - idem. Voor wortel s u in Mlg., zie blz. 292.

SUP, Nu(P). Sam., Mao. nun u - duiken, F. n un uva - duiken naar (V. G. V 58), Jav., Mal., Soend. sus u p - ergens in, onderdoor, doorheen kruipen, Mad. s o s op - zich verschuilen, zich dringen in, Bat. Mand. susup - ondergedoken, ondergedompeld, Mak., Boeg. s o s o' - doorkruipen, Bar. s u s u - binnendringen, binnenkruipen, Tag. Bagobo so sop - idem.

TAK, NAK. Tag. na knák - ontsteking, verzwering, Bis. $\mathrm{naknak}$ schudden, heftig bewegen, Jav. ț a k - klanknabootsing van kloppen, Bat. Mand. mat u ta kta k - klappertanden, Mal. bĕ r děta k kloppen, v. h. hart, dit laatste zou ook van den verwanten wortel t ěk kunnen zijn. De beteekenis van het Tag. woord moet aan het kloppen der wonde ontleend zijn.

TAS, NAS. Tag. n a s ná s - versleten, Bis. helder daglicht, Jav. t a t a s - geheel door (gesneden, gebroken, gestoken enz.), geheel weg, afgedaan, Ilk. n a snás - schoon door wrijven (ziet dus op het degelijke wrijven), Soend. t a t a s - geheel door enz., vandaar: open, klaar en duidelijk, de beteekenis van Bis. nas ná s sluit daarbij aan.

1) Ook s a p s a p - wegvagen (Neumann, Karo-Bataksche Spraakkunst blz. 74 (Verh. Bat. Gen. LXIII, 4). 
TĔG, NĔG, zie blz. 343 .

TĔNG, NĔNG. Tb. n ěng n ĕng - suizen, blazen, Tb. t ĕng t ĕng - een soort kleine bij.

TĚL, NĚL. Bat. Mand. nol nol - stijf op iets gericht, v. d. blik, tol tol - strak aangetrokken, stijf gespannen.

TER, NER; (TAR, NAR). Tont. n a'ne r - bij een zacht vuur roosteren, t a 't e r - dichterbij brengen, inz. tot het vuur.

TES, NES. Mal. nenes - doorsiepelen, v. vochten, (als gw. opgevat), Soend. te s, u.b. vóór: vallen van druppels, Jav., Soend. te tes druppel.

TING, NING. Tag. n ing n ing - gloeien, Jav. t ing, ět ing - lantaarn. I TIS, NIs. Tb. $\mathrm{n}$ i in is - druppelen, O. Jav. tit is - druppel, t a r it is - biggelen, Tont. titis - afdruipen.

II TIS, NIS. Jav. $\mathrm{n}$ is $\mathrm{n}$ is - in de koelte, $\mathrm{t}$ is $\mathrm{t}$ is - koud.

To, No. Tont. no no - koken. Wortel is to $(\mathrm{t} u)$, waarvan Day. $\mathrm{t}$ in oaangebrand, Mak. ti'no' - gaar, rijp. [De beide hamza's zijn vreemd, 't infix is in !] Tag., Bis. luto - koken; Tb. dutu koken, rijpen. Zie verder boven blz. 294 s.v. $\mathrm{t}$ i n o.

(ток), NOK; TUK, (NUK). Soend. na rok nok - uitkomen v. d. haren v. baard, knevel en de schaamdeelen, Tont. t u't u' - vuurvonk, Jav. ět uk - bron, oorsprong. Met verwante wortels: Soend. ma t a k - oorzaak, b a těk - een wapen uit de scheede trekken, Jav. w a těk - aard, Soend. m ěl ět e k - opkomen, boven den horizon verschijnen.

Tu, Nu. Bis. Seb. n ù n ò - neerdrukken, Bis. Hil. nô nô - verpletteren, drukken tegen, Bis. Sam. Leyte nônô - neerdrukken, een dier met een wapen dooden, Bkl. no no - niet heelende wonde; Jav. t ut u - stampen, v. rijst.

TUH, NU(H). Sam. nui - toenemen, Jav. $t u t u h$ - toenemen, Sam. Mao. nun u - in menigte bijeen zijn.

TUNG, NUng. Bat. Kar. n ung n ung - trachten uit te vorschen, bv. wie iets gestolen heeft, Soend. $\mathrm{t} \mathrm{ung} \mathrm{g} \mathrm{ung}$ - einde, eindpunt, Mal. it un g - berekening, Soend. kun t ung - peukje v. é. sigaar, rest v. e. fakkel e.d. - In den wortel t u n g ligt de beteekenis ,naar het eindpunt toe'".

I TUT, NUT. Bis. nunót - volgen, Ilk. nun ot - geduld, gelatenheid, de wortel t ut is als zoodanig in het Jav. in gebruik: volgen. Afgeweken zijn: Tag. $\mathrm{n} \mathrm{u} \mathrm{not} \mathrm{-} \mathrm{verzachten} \mathrm{(men} \mathrm{zou} \mathrm{verwachten}$ zachtmoedig, volgzaam), Png. no not - zich herinneren, denken, Ibg. no not - overdenking, gedachte. 
II tUt, NUt. Van een ander tut, aanwezig in Soend. but ut - versleten, Bat. Mand. n u n u t - versleten. De geredupliceerde of herhaalde wortel komt niet voor.

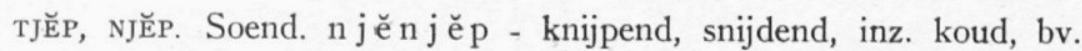
wanneer men de hand in ijskoud water steekt, $\mathrm{n} \mathrm{j} \mathrm{ĕn} \mathrm{j} \mathrm{ĕ} \mathrm{pa} \mathrm{n} \mathrm{-} \mathrm{de}$ koorts hebben, $\mathrm{t} \mathrm{j}$ ĕ $\mathrm{p}$, u.b. vóór : $\mathrm{k}$ a ra s a t i i s - koud aangevoeld, Mal. t j ĕt j a p - met de punt van de tong proeven, Jav. t jĕt j ěp - de lippen ergens even aanzetten (om te drinken), Soend. een geldstuk op een wond leggen om de bloeding te stuiten;

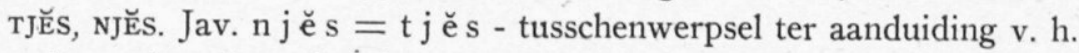
door plotselinge koude aangegrepen worden; $\mathrm{n}$ j ĕn $\mathrm{j}$ ěs - koud, koel (voor het gevoel) P., t j ĕstj ěs a n - huiverig, rillerig.

TJIR, NJIR. Jav. n j i n j i r - zacht op het gevoel, Soend. 1 ö t j i r - glad, bv. v. vel.

TJUR, NJUR. Day. n j u n jur - gesmolten, Jav. zacht, pap geworden, mollig, Bat. Mand. hantjur - diarrhee, Soend. hantjur bereide verf, fijne metselspecie, Soend. a n $\mathrm{j}$ u r - gesmolten, week v. gemoed.

TJONG, NJONG. Mal. n j on j on g - vooruitstekend (bovenlip), Soend. t jong, u.b. vóór: $\mathrm{nj}$ ĕmbah (ziet op het opsteken der met de palmen tegen elkaar gelegde handen), Soend. $\mathrm{tj}$ on $\mathrm{gtj}$ ong - steken, pikken.

I WAK, MAK; WĔK (WÖK), MĔK. Soend. mak mak měk mĕk - belust, begeerig (eten, kleeren), wa kw a k wökw ök - idem.

II WAK, NGAK. Day. ngakngak - snateren (meerv.), Jav. ngak ngak (gans) en wakwak (an), Sas. nga' - taling.

Aan w beantwoordt de nasaal $\mathrm{m}$, hier vindt men $\mathrm{ng}$, $\mathrm{w}$ is dus na de nasaal uitgevallen evenals in weta n - ngetan. Geheel overtuigend is het geval niet daar er ook wortels $\mathrm{kak}$ en $\mathrm{gak}$ zijn. Allen zijn geluidnabootsend en niet goed uit elkaar te houden, bv. $\mathrm{g} \mathrm{a} \mathrm{k}=\mathrm{kak}$, een krassend geluid, in: Jav. g a g a k - kraai, raaf, Soend. g a g a k, g a a k, k a a k (beide laatsten met vocaalsplitsing), Bat. Mand. ka k, Bat. Kar. kāk, doch Bal. gowak. Ka k wordt voorts gezegd van kakelen v. hoenders $=\mathrm{kok}$, bv. Mal., Tag. kakak, Day. ook: gagak, als zij een ei gaan leggen, O.Jav. $\mathrm{kakak}$ en angak, maar ook van lachen: Jav, t jakakak, Soend. tjatjalakatakan (met verandering van $k$ in $t$ ), Day. kakak, Bat. Mand. hakkak, Sas. kakak, doch Boeg. Mak. ka'ka' - kwaken van eenden.

Bat, Kar. bak, dus = wa k, is een geluidnabootsing (dravend 
paard), Soend. wak is u.b. vóór: dibölah - in tweeën gedeeld, i.c. door openscheuren, O.Jav. $\mathrm{ngak}$ is een klanknabootsing van het geluid van rollende wagens, $\mathrm{ngakngak}$, idem v. e. draak, Tb. ng a kng a k - een soort zeemeeuw, vermoedelijk dezelfde als Tont. nga'ngak Tons. ngakngak - naam v. e. roofvogel genoemd naar zijn geluid: ngak! ngak!, Bat. Kar. ng a k - klanknabootsing: pats!, Bat. Kar. n g a kn g a k - een keel opzetten, kan van kak zijn; Day. ng a k wordt van kwaken van eenden en babbelen van kinderen gezegd.

WEK (век), мек. Mal. m e me k - drijnen, v. kinderen, Soend. w e k wek - kwekken, een bek opzetten, doch: wakwak wekwek snateren, v. eenden, Bat. Mand. be k be k - al maar door praten, een brutalen mond zetten.

wок, мок. Jav., Mal. momok - spook (naar het geluid dat zij maken ?), Soend. w ok, u.b. vóór : di b ě d a h - doorgebroken, w a k wok vóór: patingkorejak, van duiven (koeren), v. ganzen (snateren).

WAL, MAL. Day. ma ma $1=$ bawal (met prefix ba-) gekneusd, Jav. wa wa 1 - uit elkander scheuren, bv. een kokosnoot.

WANG (BANG), MANG; WĔNG (BĔNG), MĔNG; WING (BING), MING. Mal. ma mang - schemeren voor de oogen, verbijsterd, Soend.m a n $\mathrm{g}$ mang - twijfelen, bing bang - in twijfel, Bat. Kar. mamang - weifelen, Mal. b i m b a n g - ongerust, bezorgd, Tont. r i m b a i m b a n $\mathrm{g}$ - twijfelend, in twijfel, Bar. s a w a n ga - onzekerheid, vermoeden zonder zeker weten. Cf. K. B. Wb. s.v. wang I, Jav. w a $\mathrm{ng}$ w a n $\mathrm{g}$ - twijfelmoedig, aarzelen, w in g w a ng - afwijkend, niet vast, twijfelmoedig, Jav. ma n $\mathrm{g}$ m a ng - twijfelmoedig, O.Jav. mingmang, N.Jav. mimang - in de war gebracht door te stappen over dooreengroeiende boomwortels (Wb. s.v.), cf. Soend. kata li mbĕng - in de war gebracht door het stappen over zekere liaan.

Soend. mĕlĕ n g m ĕng - onduidelijk, niet zichtbaar in de details, iets als in een nevel zien, Tb. $\mathrm{r}$ ĕ $\mathrm{mbĕ} \mathrm{ng}$ b ĕn $\mathrm{g}$ - donker, Tont. ri mbě i m b ěng - duister, donker.

Daar Tont. rimbaimbang en rimběimbĕng ongetwijfeld samenhangen is het duidelijk dat de oorspronkelijke beteekenis van w a ng (bang) en nevenvormen ,donker, duister” is en ,twijfelen" een afgeleide beteekenis.

WAR, MAR. Jav. ma ma r - schemeren, v. d. oogen, zoodat men niet duidelijk zien kan, Soend. haliw a w a $\mathrm{r}$ - een weinig beginnen te 
schemeren, schemerdonker, sa ma r - verborgen aan iemand. WIS, MIS. Jav. $\mathrm{mi}$ m is - geweer- of kanonkogel, ook: kleiballetje voor een blaasroer, Soend. $\mathrm{m}$ i m is - hagel, Tb. w is w is - suizen, v. d. wind. Het woord $\mathrm{m}$ i $\mathrm{m}$ is is natuurlijk ouder dan de bekendheid met kruid en lood, de naam ziet blijkbaar op het suizen van het kleiballetje uit het blaasroer en moet later op andere projectielen zijn overgebracht.

WONG, MONG. Jav. mongmong - verzorgen, Jav. wong wong beschermen, toezien op, Soend. mongmong - zijn eigen zin doen (C. ngamongmong) doch ook: vertroetelen, mong mong diri - zijn eigen zin doen, lett. zichzelf verzorgen, verwennen.

WOR, MOR. Jav. momor - dooreengemengd, Jav. wow or - idem.

't Spreekt welhaast van zelf dat de beteekenissen van wortel en nasaleering daarvan elkaar vaak niet geheel dekken. 't Is een universeel verschijnsel dat de beteekenis van een woord in verschillende talen pleegt uiteen te loopen. Zelfs zeer concrete begrippen als: huis, akker, namen van gewassen, ontkomen daaraan niet. Bovendien leidt verschil in klankverloop tot diffenrentieering van beteekenis (V. G. IX 257 v.v.). Maar in beginsel - dit moge uit de hier gegeven voorbeelden duidelijk zijn geworden -, zijn een wortel en zijn nasaleering gelijkwaardig.

Van $l$ en $r$ bestaan geen genasaleerde omzettingen, evenmin van $j$, waarvan het zelfs twijfelachtig is of er een met deze semi-vocaal beginnende wortel bestaat.

\section{Grondwoorden met vóór-syllabe.}

De derde wijze van vorming van grondwoorden bestaat in het voegen van een willekeurige, open syllabe vóór den wortel. Als zoodanig kunnen alle aksara's optreden met uitzondering van $j a$ en zij kunnen dragers zijn van alle vocalen, bovendien kunnen vocalen worden voorgevoegd. Bij de Soend. umpak basa is dit anders. De monosyllabische umpak basa zijn wortels, zij kunnen op dezelfde wijze, door vóórvoeging van een willekeurige, open syllabe, worden verbreed. 't Verschil is echter dat bij een grondwoord de vóórvoeging een nieuw begrip schept, terwijl de verbreeding - uit den aard der zaak kan zij 't zelfde foneem zijn als de vóór-syllabe die het grondwoord vormt. - de beteekenis der umpak basa dezelfde laat, haar alleen intensiever maakt, bv. g ĕt jok $=\mathrm{t} \mathrm{j} \mathrm{ok,} \mathrm{u.b.} \mathrm{v.} \mathrm{pikken,} \mathrm{maar}$ 
g ĕt o k gw. van „kloppen op”, van wortel to k waarin de beteekenis „,kloppen, slaan tegen” ligt; $\mathrm{d}$ j ĕ blu s $=\mathrm{b} 1 \mathrm{u} \mathrm{s}$, u.b. met beteekenis , ergens ingaan, indringen", doch d j ĕp i t - nijptang, bankschroef, van wortel pit waarin de beteekenis ,drukken, knijpen” ligt. Men vindt de zelfde syllaben vóór wortels van uiteenloopende beteekenis zonder dat zij een anderen invloed op den wortel uitoefenen dan in samenstelling daarmee een woord te vormen. Een eigen beteekenis heeft de vóór-syllabe niet. Dit is geheel anders als bij de formatieven, deze drukken hun stempel op het woord waaraan zij verbonden worden bv. in het formatief k a - ligt de beteekenis ,geslaagd". Plaatst men dit vóór verschillende begrippen, bv. Soend. $\mathrm{k} \mathrm{a} \mathrm{b} \mathrm{a} \mathrm{w} \mathrm{a} \mathrm{-} \mathrm{meegenomen,}$ $\mathrm{k} \mathrm{a} \mathrm{buru}{ }^{\circ}$ - achterhaald, kat u $\mathrm{lis}$ - geschreven, enz. dan komt in alle deze gevallen tot uitdrukking dat de handeling inderdaad haar beslag heeft gekregen, is geslaagd. Dat is hetgeen men door gebruikmaking van het prefix heeft willen zeggen. Bij de vóór-syllabe is van iets dergelijks geen sprake. Een enkel voorbeeld zal voldoende zijn.

Met vóór-syllabe tě-zijn in het Jav. samengesteld: těka komen, tot aan, van af; t ĕ b u - suikerriet; t ěr a ng - helder; t ĕ b a k - slaan op, gegrepen, neergeslagen; t ěk ěk - beetpakken; t ěk ěm toegesloten hand. - těka $=\mathrm{t} \check{\mathrm{e}}+\mathrm{ka}$, vgl. sang ka, sa ka dat ook ,,van af" beteekent, k a Mal. Soend. - naar;

de wortel van těrang is in het Oud-Jav. over als rang, ḍang doorschijnend, doorlicht, cf. Soend. he rang - helder, Tb. rung d a n $\mathrm{g}$ - rood, gloeiend;

těbu, Mon $\beta$ ãu, Khmer ābāu;

t ĕ b a k, in den wortel b a k ligt de beteekenis ,,tegen iets aankomen, werpen tegen, treffen, slaan ${ }^{1}$ ), Soend. kobak - spel waarbij moentjangnoten e.d. in een kuiltje worden geworpen, Jav. o mbak - golf, $\mathrm{ta} \mathrm{mbak}$ - schutsweer, waterkeering;

t ě k ěk, k ěk is Soend. u.b. vóór : vastpakken, aangrijpen enz.; Jav. b ěngkĕk - bijeengebonden pakje;

t ě k ĕ m, de wortel kĕm staat gelijk met k ĕp, beteekenende ,,vasthouden, grijpen, omsluiten, vast aaneen", Jav. t ing k ěm - mandje met vier sluitkleppen, Jav. bu ng k ěm - iemand den mond dichthouden.

Deze afleidingen met voorgevoegd $\mathrm{t} \breve{\mathrm{e}}$ - hebben niets gemeen in den trant der hoogergenoemde $\mathrm{ka}$ - vormen, het voorvoegsel heeft dus geen eigen inhoud en slechts door de vereeniging met een bepaalden

1) Boven blz. 324 s.v. p a k, b a k. 
wortel ontstaat een woord waarin men de beteekenis van dezen terugvindt.

Langs den omgekeerden weg komt men tot hetzelfde resultaat. In den wortel k a p en varianten k ě p, kö p, k e p, k i p, k u p, k o p, liggen de beteekenissen zooeven bij kĕm genoemd, bv. B.M. kulika p schutbladeren, Soend. dakĕp - de handen over elkaar geslagen, Soend. kököp - overdekken, bedekken, toedekken, Soend. rekep - vast gesloten, B.M. k a li k i p - vleugel, Soend. 1 in g k u p - gesloten, dicht, Soend. la k o p - klamp. In vele talen komt een woord met dezen wortel samengesteld voor, dat ,grijpen" beteekent, bv. Jav. Soend. ta ngkěp, Tag. dakip, Bis. dakop, Tb. sikop, B.M., Ponos. si ngkap, Bent. ra ku p, de vóór-syllaben zijn verschillend maar de beteekenissen der woorden zijn gelijk, de vóór-syllaben hebben geen eigen beteekenis.

Verschillende vóór-syllaben kunnen bij eenzelfden wortel geplaatst worden, vormen dan verschillende woorden met verschillende beteekenis. Zij détailleeren het begrip van den wortel dat altijd ruim en vaag is. Met wortels vergeleken verfijnen en preciseeren grondwoorden de taal.

Hier volgt een reeks grondwoorden met voorbeelden van alle aksara's en alle klinkers die als vóór-syllabe optreden; van elke aksara één voorbeeld, er zouden er zoovelen te geven zijn als het aantal klinkers dat in verbinding met één aksara optreedt, bedraagt. De voorbeelden zijn aan het Soendaasch ontleend omdat deze taal over wortel-umpak basa beschikt, waarvan de beteekenis aan de woorden waarbij zij gebruikt worden, te toetsen is.

k ě -, k ě bul - opstijgen (rook of damp), opstuiven (stof), wortel is bul, u.b. bij ngukus - wierook branden, nga mbul - boven drijven;

g a -, g a 1 u r - achtergelaten spoor, wortel 1 ur, u.b. bij diting g a lkö n - achtergelaten, dia lu r - spoor nagelaten;

t ju-, t junduk - aangekomen, wortel duk, u.b. bij ka aluna 1 u n - (aangekomen) op de aloenaloen;

d j a -, d j a mbul -kuif op den kop, zie kĕbul;

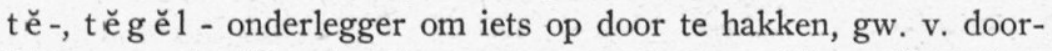
hakken, wortel gěl, u.b. bij pot ong - gebroken, dit ug ěl - afgeslagen, afgesneden;

d ě-, děng ek - schreeuwen, gillen, wortel ngek, u.b. bij t a rompet - (het geluid van de) trompet; 
pa, patjok - pikken (als een kip), wortel tjok, u.b. van patjok;

bo-, botjor - lek, lekken, wortel tjor, u.b. bij ditjaian water op gegoten, ook: (afstroomen van water);

h u -, hulĕng - in gepeins verzonken, peinzen, wortel lĕng, u.b. bij: kapowekan - (als het iemand duister voor de oogen wordt), de kluts kwijt raken, kapi juhan - in zwijm vallen, ngahulĕng, als hulĕng, tö e mut - buiten kennis geraken, $1 \mathrm{ijör} \mathrm{-} \mathrm{duizelig}$ worden, t unduh - slaperig worden, kat orekan - verdoofd;

ro-, r o n tok - zich met kracht op iets of iemand werpen, wortel t ok, u.b. bij toktok - tikken, kloppen, kĕtok - kloppen met de hand, afslaan van het hoofd;

si -, silěp - uit het gezicht zijn, uit het oog verdwenen zijn, in iets op- of overgegaan, wortel lĕp, u.b. bij: tölöm - in het water zinken, ka lĕbuh - vergaan, v. e. schip, tö da ta ng - niet gekomen, k a lĕm - zinken, wegzinken, di s ěla pkön - ergens tusschen gevoegd, ng a 1 ěl ěp - wegzinken;

1ĕ -, lě g u r - snorken, wortel g u r, u.b. bij h u r u ng - branden, sönö ngagudag - het vuur brandt hevig, mirun sönö - vuur aanmaken;

w ě -, w ě d a r - losgaan, vrijlating, wortel d a r, vgl. o e d a r - losgaan, da da r uitgespreid, in extenso mededeelen;

a -, a ba r - glans, uitstraling, wortel ba r, u.b. vóór ng a mpa r uitspreiden, een mat bv., la jarna -het zeil werd ontrold;

ě -, ěle b - rijzen, stijgen, inz. van water, wortel leb-, u.b. vóór: pin u h - vol (niet alleen met een vloeistof);

e -; e b o g - zich nederleggen, wortel bog, u.b. bij hetzelfde;

$\mathrm{i}-, \mathrm{i} b \mathrm{e} \mathrm{r}$ - bode, gw. een persoon of bericht vooruit zenden, wortel bĕ r, u.b. bij : h i b ĕ r - vliegen, n a r a d j a n g - zich op iemand storten, ngodjaj patarik-tarik - om het hardst zwemmen, di pěnta ng - spannen v. e. boog (waarbij te denken dat de pijl wegvliegt), nubruk - zich op iemand storten;

$\mathrm{u}$-, u b ĕ $\mathrm{r}$ - nazetten, najagen, wortel b $\mathrm{c} \mathrm{r}$, zie boven;

o-, obrol - al maar uitgeven, wortel brol, u.b. bij ng a d j u r u - bevallen;

ö-, öntöp - zitten, als een vogel op een tak, wortel töp, u.b. vóór öntöp.

$\mathrm{Bij}$ grondwoorden waarvan de tweede lettergreep met $r$ of $l$ begint, moet men er op bedacht zijn dat zij ook wortels met een infix : vocaal 
$+r$ of vocaal $+l$ kunnen zijn, als in hoofdstuk II beschreven. Is die tweede lettergreep een bekende wortel en heeft het grondwoord een verwante beteekenis, dan heeft men kennelijk met een grondwoord der derde categorie (wortel met vóór-syllabe) te doen, zoo bv. is Jav. Mal. Soend. těluk - bocht, baai, inham $=t \breve{e}+1 \mathrm{uk}$, want $1 \mathrm{uk}$ is een wortel met beteekenis ,krom, gebogen”: Soend. hĕluk het hoofd nederbuigen, Jav. pěluk - omvat, omhelsd, Mal. ka luk - bocht, kromming, krul in figuren, Day. ka lok - krom gebogen, Tag. pilok - omdraaien, bv. het scherp v. e. mes, Tag. 1 u ók golf, baai, Bat. Mand. haluk - omhelzen, ergens de armen omslaan. - Doch Soend. p ulung - bijeengaren, v. d. grond opnemen, a n a k pulung - aangenomen kind, Oud-Jav. pulung - verzameling, is niet met een wortel l $\mathrm{ung}$ in verband te brengen, hier is de wortel pung met infix - ul-, zooals blijkt uit Soend. gampung - aren lezen, Soend. g ĕ m p un g - zich verzamelen, Soend. i m p un g - druk bezoeken, kaimpungan - aangehangen worden, door de menschen, impun - bij elkander, Soend. pung pung - in menigte komen, ook Mal. k a m p ung - verzameling v. woningen, gew. Soend. plaats in het huis waar men tesamen zit, behooren hiertoe.

Een ander punt van verschil tusschen grondwoorden - er is hier steeds sprake van die der derde categorie - en verbreede umpak basa is dat bij de eersten de vóór-syllabe een nasaal kan zijn, bij de laatsten is dit nimmer het geval.

Bezien wij de met nasaal $(m, n, n g, n j)$ beginnende grondwoorden nader, dan blijkt een belangrijk gedeelte geen grondwoord te zijn. Om dit aan te toonen zal de staat van zaken in het Maleisch worden nagegaan (woordenboek van Ronkel).

Met een nasaal beginnende vreemde, vooral Sanskrit- of Arabische woorden doen hier niet ter zake, omdat het om Indonesische worrden gaat, men kan het aantal met nasaal beginnende grondwoorden er stilzwijgend mee verminderen.

Voor alle deze met nasaal beginnende grondwoorden geldt verder dat er onder zijn die, naar de wijze in het vorige hoofdstuk beschreven, door reduplicatie of herhaling van genasaleerde wortels gevormd zijn, zij gaan op een zuiveren wortel terug.

Overigens zijn de volgende opmerkingen te maken: 


\section{a. met $\mathrm{m}$ beginnende grondwoorden.}

Een belangrijk aantal namen van boomen en andere planten, ook wel van dieren en enkele andere zaken begint met $\mathrm{ma}-, \mathrm{ma} \mathrm{r}-, \mathrm{m} \mathrm{a}^{\mathrm{ns}}$. Dit is niets anders dan het bekende actief-prefix, dat in deze samenstelling in alle talen voorkomt, in de Filippijnsche talen treedt het bij plantennamen zeer op den voorgrond. De taal behandelt ze als grondwoorden, maar het is duidelijk dat het eigenlijke grondwoord het woord ontdaan van dit prefix is, bv. maranti, de Cl. $3114^{1}$ ), ma r li ma u - lemoen, citroen, ma m pěla $\mathrm{m}$ - de Cl. 2169, zijn van de grondwoorden ranti, li ma u, pěla m - smoutig, Jav. pělĕm.

Namen van dieren, met ma - beginnende, zijn o.a. maraga i hop (vogel), gw. ragai, marsudji, een zeevisch. gw. sudji, Soend. sudji - stekel, Jav. sudjen - pen om iets aan te rijgen.

Mal. banalu of binalu - de Cl. 2096, luidt Bat. bandalo, Lamp., M. K. bindalu, gw. is dalu, er bestaat een tweede Mal. naam manalu. Dit is vermoedelijk een analogie-vorming. Zoo iets komt meer voor: $\mathrm{mangkudu}=\mathrm{bangkudu}$ - Ind. meekrapboom, de Cl. 2343, mangkuwang = bangkuwang - knolgewas, de $\mathrm{Cl}$. 2532. Ongetwijfeld is de tweede vorm de oorspronkelijke, b a n g k u d u = Soend. t ja ng kudu, wat beantwoordt aan een niet meer bekend Jav. wangkudu, het Jav. heeft wel mangkudu, wederom vermoedelijk analogisch gevormd. B a $\mathrm{ngk} \mathrm{uw}$ a $\mathrm{ng}$ is wijd verspreid (Soend., Day., Mlg., Tag.); van Mal. mangkuwang geldt m.m. hetzelfde.

Eenige woorden zijn actieve werkwoordsvormen waarvan $\mathrm{ma}$ - is afgevallen, in het Maleisch komt dit weinig voor, in het Javaansch is het regel; bv. ma ung - onaangenaam riekend, van ma ma ung, gw. baung, gesloten vorm van bau, cf. Jav. ambu - reuk, ngambung - ruikend kussen; - měnang - winnen, van m a m ĕna ng, gw. wĕn a ng, Jav. w ĕna ng - macht en recht hebben over iets; - mĕng ung - mijmeren, van ma mĕng ung, gw. běng ung, Soend. bĕng ong - met open mond versteld staan te kijken; - měnt jak - zwaarddans, pĕnt jak - idem, het eerste staat voor ma mĕ $\mathrm{t} \mathrm{j} \mathrm{a} \mathrm{k} \mathrm{en} \mathrm{beteekent} \mathrm{dus} \mathrm{eigenlijk} \mathrm{,,den} \mathrm{zwaarddans}$ uitvoeren"; - mumbung - tot overloopens vol, van mamu$\mathrm{mbung}$, gw. bumbung, cf. Soend. k a b ěmbĕng - niet tot braken, tot afgaan, tot baren kunnen komen; - maling - dief, van

1) F. S. A. de Clercq, Nieuw plantkundig woordenboek van NederlandschIndië. - Amsterdam 1909.

D1. 102. 
mamaling (de actieve werkwoordsvorm kan ook nomen zijn, zie boven blz. 282), gw. paling - Soend. diefstal; - mint a - verzoeken, is van maminta, gw. pinta, O.-Jav. pinta; - mukah overspeler met een gehuwde vrouw, overspel, van ma mukah, gw. pukah, Soend. pukah - losgaan, scheiden; - mogok - staken, is van mamogok, gw. pogok, Jav. pogok - ongehoorzaam zijn aan een bevel van de overheid, staken, mogelijk is dit woord uit het Javaansch overgenomen.

Eenige der genoemde woorden zouden in stede van met prefix $m a{ }^{n}-$, met infix - $\mathrm{um}$ - afgeleid kunnen zijn, bv. měnt ja k voor pumĕntjak, doch aangezien - um - als formatief in het Maleisch reeds in een ver verleden verloren is gegaan, is een afleiding met $\mathrm{ma}^{\mathrm{n}}$ - waarschijnlijker. Hoe dit zij, voor het gw. maakt het geen verschil. Zoo kan ook mohon - beleefde ontkenning, uit mamohon - smeeken, bidden, gw. pohon, verkort zijn, doch 't kan ook staan voor sumohon, met weglating van de eerste lettergreep, van een verloren gw. sohon, Soend. suhun - op het hoofd nemen, waarvan in het Soend. panuhun - beleefde afwijzing; - mong gol knoestig, is van mamonggol, gw. bong gol, cf. Jav. bonggel, b ong gol - stengelknol, (dikke) ondereinde v. e. plant, cf. Soend. bĕnggul - bult; - mongkok - boven de omgeving uitsteken, gw. bongkok, cf. Jav. běngkak - gezwollen; - m ĕngka 1 nog niet rijp, v. vruchten, cf. Jav. bungkul - bloemknop; mĕg a t - stilstaan, v. e. tol, gw. pěg a t, Jav. Soend. pĕg a t - gebroken, dat echter ook beteekent ,,in den weg treden, versperren; mutu - stom, van mamutu, gw. butu, Jav. buntu - doodloopend, ook: verstopt; - mant jung - spits, puntig, pant jung slip v. e. kleed, punt, sleep, Soend. pant j ung - uitsteken, vooruitsteken, bv. een groote neus.

Zekere - $\mathrm{um}$ - vormen zijn: $\mathrm{minum}$ - drinken, gw. in u m, in vele talen bewaard; - mangkar - halfgaar, halfrijp, Bat. Mand. angkar; - mati - dood, gestorven, is van pati - dood (subst.); - mĕring - mager als een dakspar, gw. ěring, Soend. ěr eng panlat; - mimpi - droom, eigenlijk: droomen; gw. i mpi, Soend. impi - droomen; m u da - jong, onrijp, licht v. kleur, moet van een gw. u da zijn, cf., met prenasaleering, Soend, ngor a - jong, Tb. ngura - jonge sirih; - mětah, in: putih mětah - spierwit, vermoedelijk gw. wět a h, cf. Jav. w ut u h - in zijn geheel, Soend. wötöh - gaaf; - mipis - dun, is van ipis, Soend. ipis - dun, een nevenvorm is tipis; - malang - wat dwars is, van palang 
- dwarsboom of a lang - dwars; - mambang - soort geesten, spoken, is v. a mbang - tegenhouden, Jav. a mbĕng - wacht houden op een plaats om den toegang te beletten; - ma mp u n $\mathrm{g}$ - licht, als puimsteen, is van ampung - licht, op het water, als kurk; - mĕkar - nog niet ontwikkeld, v. vruchten = s u m ěk a r, Jav. su měka r - opzwellen, gaan bloeien (V.G.V. 116), gw. sěkar; - makin, mangkin - zooveel te, des te, ook sěmakin, š̌mangkin, is van sakin, sangkin, met - uminfix, Jav. mangkin, sĕmangkin, Soend. sumingkin, gw. singkin; - měnda p - bezinksel, eig. bezinken, is van ěnda p bezinken; - m ĕ n da k - bukkend naderen, is van pĕ ndak, Jav. pěḍak, pĕḍĕk - dichtbij; - miring - hellend, is van iring, iringan - schuins achter, Jav. (zij) kant, dii r ing a ke - hellend, scheef gezet; - m u d j u r - rechtuit, is van $\mathrm{udjur}$, Soend. udjur - in het lang, recht op aan, Jav. udjur richting, lengte (uitgebreidheid); - mulas - koliek, is van pulas, Jav. mulĕs - buikpijn hebben, pulěs - in elkaar draaien; muntah - braken, is van untah, Soend. utah, of van buntah, Jav. w utah; mondok - kort en breed, is van poridok, Soend. pondok - kort; - mara - voorwaarts, is van para, O.-Jav. pa r a - gang, komen, gaan; - ma ng u t - suffen, mijmeren, is van a n g u t, cf. Soend. a ng g ut - zich nu voorover, dan achterover buigen, ung g u t - knikkebollen; - ma mp u s - dood, gw. a mpus, Jav. a m pus - uitgewischt, gedelgd, pupus - dood; - mĕnung in gepeins verzonken, van een niet bekend gw. h ěn ung, doch vgl. Jav. mĕn ěng - zich stil houden, v. ěn ěng, Soend. hĕnĕng.

De volgende woorden zijn wortel-actieven, ma- vormen direct van een wortel afgeleid (zie boven blz. 279 v.v.): $\mathrm{m}$ a k a n - eten, van wortel ka n - eten; - mabuk - dronken, van buk dat ,hard slaan” beteekent, cf. Soend. ba buk, met prefix ba -, in het wilde er op in houwen; - masak - gaar, rijp, Soend. a sak - idem, wortel sak; - masam - zuur, Soend. a šm - tamarinde, doch has öm - zuur, O.-Jav. a söm - tamarinde, ha sĕm-a s ěman - zuur (subst.) J., wortel is sĕm, söm; - masin = a sin - zout, ziltig, brak, wortel-sin; - masuk - binnengaan, vermoedelijk $\mathrm{ma}+\mathrm{suk}$; - madjun - gekneed, deeg; van denzelfden wortel Soend. Jav. pandj u n a n - pottenbakker, eig. kleikneder, vgl. Bar. ewa ndapamont ju - alsof het gekneed is, (mo)montju - pottenbakker, Soend. tukang andjun - pottenbakker, Mal. madjun moet oorspronkelijk ,kneden, de pottenbakker" beteeekend hebben; 
- měntah - rauw, onrijp, wortel t a h, Soend. a ta h - idem; ma sih-nog, meer, is van wortel sih, ook aanwezig in Jav. is i h nog; $\mathrm{m}$ a 1 a m - nacht, wortel 1 ă m, Indon. 1 ĕ m, beteekenende ,het binnenste, het diepe” en hieraan wordt tevens de beteekenis „donker” verbonden. - Van den gelijkwaardigen wortel lĕp komt ma la p smeulen; - ma mpat - vast in elkaar, in pat, p ĕt liggen o.a. de beteekenissen ,op iets drukken, dicht op iets zijn, bedekken”', bv. Soend. $\mathrm{t}$ u p a $\mathrm{t}$ - de dopjes op de schil van de manggistan (waaraan men het aantal partjes tellen kan), $\mathrm{r}$ a pĕt - goed aansluiten; - $\mathrm{ma}$ sing-masing - ieder afzonderlijk, is van sing, Soend. sing ieder, iedereen, alleman, elk afzonderlijk; - $\mathrm{mampu}$ - in staat zijn tot iets, bij machte zijn, van $\mathrm{mpu}$ - meester; - mas s i - erg in de war, v. h. haar, wortel s a i - uitgeput (boven blz. 327).

Voorts is nog mantuwa - schoonouders, afgeleid van tuwa (V.G. IV 278), mampělai - bruid, bruidegom, is van pělai achterlaten, in bewaring geven, terughouden, maruwap - uitwasemen, is van u wa p - wasem; marsik - schel, v. geluiden, droogkrakend, wortel sik, cf. Jav. wisika n - (nacht)wind, bisik fluisteren; morong - pot met handvatsels, Jav. morong en porong; mĕling - onverschillig, onoplettend, nalatig, wortel ling. De variant lĕ $\mathrm{ng}$ is in het Soend. u.b. vóór: de kluts kwijt zijn, weg zijn in gedachten; man $\mathrm{gkuk}$ - kopje, is van kuk, zie boven 282; malu - beschaamd, cf. Jav. ba 1 o en balu (Pigeaud) - verhinderd, belemmerd, van de kook, de beteekenis ,bedremmeld, beschaamd" staat hier niet ver van af, de wortel is $1 \mathrm{u}$, Mal. Jav. ng ĕ $1 \mathrm{u}$ - hoofdpijn hebben, Mak. ngallo - idem. De gesloten vorm is $1 \mathrm{ung}$, Soend. ling 1 ung - vergeetachtig, p a l ung - onverstandig, dwaas, silung - niet in de haak. Vgl. boven blz. 292 s.v. 1 u mó, of dit denzelfden wortel bevat lijkt mij onzeker; de beteekenis wijkt af. Andere gevallen zijn in hoofdstuk II behandeld ${ }^{1}$ ).

't Aantal met $m$ beginnende woorden waarvan na dit vluchtig onderzoek het grondwoord nog niet kan worden aangewezen, bedraagt slechts een fractie van het totaal en zou bij diepergaand onderzoek ongetwijfeld verder dalen.

1) $\mathrm{mata}-\operatorname{oog}$, is vermoedelijk t a met prefix ma-, letterlijk: oog zijnde, het ziende, vgl. Siameesch t à - oog, t a w a n - zon, letterlijk: oog van den dag, vgl. Mal. mata hari, Soend. panon powe, Mak. mata a 11 o, Boeg. m a t a ěs s o. (K. Wulff, Chinesisch und Tai, blz. 210. - Historisk-filologiske Meddelelser Danske Videnskabernes Selskab XX, Kopenhagen 1934). 


\section{b. Met $\mathrm{n}$ beginnende grondwoorden.}

Van met $n$ aanvangende grondwoorden vallen te noemen: $\mathrm{naik}$ stijgen, staat voor manaik, gw. daik, Tag., Bis., Bkl. dahik stijgen; - nakal - stout, ondeugend, baldadig, van manakal, gw. dakal, Jav. ḍangkal - weerbarstig, eigenzinnig, ongehoorzaam; - namnam $=\mathrm{njamnjam}$, zie boven blz. 317 . In het Maleisch wisselen $n$ en $n j$ aan het begin van een woord; - na m pa l, n a p 1 - eetbare aarde, mergel, is van m a n m pal, man a pa $1, \mathrm{gw}$. t a p a 1, Soend. t a p ěl - kleverig, de naam doelt dus op kleiachtige aarde; - nanti - aanduiding v. d. toekomenden tijd, mananti wachten, gw. a n ti, Jav., Soend. a n t i - wachten, de $n$ is onregelmatig voor $n g$; - n a ung - lommer, schaduw, beschutting, man a ung $\mathrm{i}$ - beschutten, gw. is s a ng, Soend. sa ung - hut, loods (op bouwland); ook: kap; - nasi - gekookte rijst, staat voor in asi, cf. Mak. Boeg. a s e - padi. Voor het gebruik van in - op deze wijze vergelijke men Tag. sinampaga - een juweel gelijkende op sampaga - een jasmijnsoort; g in ulang - groenblauw, gulang - groenten; k in a r a y u m - lange, dunne rijst, ka ra y u m - naald; (i) n a si wil dus zeggen ,,wat op paddi gelijkt maar toch niet hetzelfde is"; - nala jan - visscher, is van manala jan, gw. sala $\mathrm{i}$ - visch boven het vuur rooken, het suffix - a n schijnt hier gelijk aan het in Mal. gebruikelijke - i; nibung, Filippijnsche talen a n ibung - een palmsoort, het gw. is diw ung blijkens Soend. handiwung. Day. ha ndiwong, Lamp. ha nibung. Boeg. a n riwu, in onbruik, te lezen: a nriwung; de nasaleering $n$ is uit prenasaleering ( $n d)$ ontstaan. De wijde verbreiding wijst erop dat de genasaleerde en de geprenasaleerde uitspraken reeds in de grondtaal naast elkaar moeten hebben bestaan —; nilai - taxeeren, gw. onzeker, doch zeker niet met nasaal beginnende; - nila m - een vogel, is van tila m, Jav. kat i la ng, met een meer voorkomende wisseling van $m$ en $n g$ als sluitconsonant; - nipis - dun, kan staan voor manipis, Tont. heeft o.a. manipis, maar kan ook ontstaan zijn uit geprenasaleerd tipis (ntipis); - nira - ongegist palmsap, vermoedelijk staande voor s in ir a waarvan si - is afgevallen. Wij zagen boven dat ook su-bij - u m - infix wel eens afvalt, gw. sir a $=$ met omzetting der klinkers s a ri, Boeg. sari - palmwijn; - nodja - een verfstof leverende struik, uit manodja, Mak. an rudja, gw. dodja.

Er zijn slechts zeer enkele $n$-woorden die nog verklaring behoeven. 


\section{c. Met ng beginnende grondwoorden.}

Deze zijn gering in aantal, ruim 20 , en hiervan behoort de helft tot de herhaalde of geredupliceerde, genasaleerde wortels (Hoofdstuk III).

$\mathrm{Ng}$ a n g u, waarvan mang a $\mathrm{g} \mathrm{u}$ - brullen, loeien, is vermoedelijk van angu; - ngangut, waarvan mangangut - mommelen, is wellicht van een gw. angut, genasaleerde wortel ngut van gut, cf. Soend. gugut, sanggut - bijten; - nge jong, waarvan mangejong - miauwen van katten, gaat terug op e jong, Soend. he jong en ejong - de schreeuw v. katachtige dieren, mejo ng in vele talen „kat”, Soend. „tijger”, doch gewestelijk „kat”, Tont. ng e ong, Bat. Kar. ng e u v. e. open vorm e u, Tont. nga ong het gemiauw der kat, Soend. ma ung - tijger, is van gw. a ung, waarnaast ha ung - gebrul v. e. tijger, Tont. heeft nog $\mathrm{mba}$ ong zeker geluid van de kat, gaat terug op wa ong ${ }^{1}$ ); - ng ĕra m brommen, van mang ĕr a m, gw. gěr a m, waarvan volgens den tegenwoordigen regel ma n g g ĕr a m - grommen, Soend. g ĕr a n g g ĕr u n g - grommen (meerv.), Mal. - $m$ wisselt weder met - $n g$ als slotconsonant elders, evenals boven nila m-katilang; - ngěran boos, spijtig, wrevelig, gw. van hetzelfde mangěram dat ook ,,boos” beteekent, gw. g ĕ r a m - woedend, toornig, boos, $n$ en $m$ kunnen aan het eind van een woord wisselen; ng a ri j a p - wemelen, gw. ri j a p, Soend. $\mathrm{rijab}$ - in menigte; - ng ĕring - het geluid v. bronzen en koperen muziekinstrumenten, d.w.z. dat geluid makende, is van ring = ding, Soend. wortel, hetzelfde uitdrukkende; - ngi a u - een miauwend geluid, gaat terug op i a u.

\section{d. Met nj beginnende grondwoorden.}

$\mathrm{n} \mathrm{jamuk} \mathrm{-} \mathrm{mug,} \mathrm{staat} \mathrm{voor} \mathrm{namuk}$ dat niet schijnt voor te komen, het woord vertoont de bekende klankverwisseling $n-l$ : Boeg. na mo', Mak. 1a mu', Jav. Tag. la muk enz., Bis. bo no $=$ bolo - kapmes; - n ja ring - duidelijk, helder v. stem, schel, schijnt van manjaring te zijn, gw. saring, Mak. sa'ring, ta'sa'ring - ontwaken, Soend. n ja ring - ontwaken, wakker zijn, ook van het gemoed, v. d. hersens gezegd; - n j a n j i - zingen. Als voren, $\mathrm{nja}=$ $\mathrm{na}, \mathrm{n} \mathrm{j} \mathrm{i}$ is geassimileerd $\mathrm{ni},{ }^{*} \mathrm{n}$ a $\mathrm{n} i$ is een open vorm naast $\mathrm{nan} \mathrm{g}$ $\mathrm{ning}$ (Jav., Soend.) en dit is de genasaleerde vorm van dangding, in het Soend. melodie, uitbrengen van muzikale klanken,

1) Anders Bat. Mand. maung-aung - schreeuwen v. pijn of angst. 
zie boven blz. 317 s.v. dang; - n jĕn j a k - vast, diep, v. d. slaap

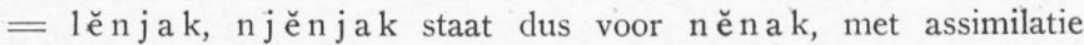
van $n$ van $\mathrm{nak}$ aan de beginconsonant; Mal. ${ }^{*} \mathrm{n}$ ĕn a k is geredupliceerde, genasaleerde wortel van den zuiveren wortel tĕg, waarvan tětěg, Soend. vast, stevig, Jav. vast, onbewegelijk blijven liggen. - Een zelfde geval is $\mathrm{n} \mathrm{ja} \mathrm{n} \mathrm{j} \mathrm{u} \mathrm{k} \mathrm{-} \mathrm{suf,} \mathrm{kindsch,} \mathrm{dit} \mathrm{staat} \mathrm{voor}$ ${ }^{*} \mathrm{n}$ a n u k, weder met assimilatie, nan u k beantwoordt aan tatuk, cf. Jav. ng a ntuk, a ntuk - slaperig, dommelig, Soend. a n tuk op zijn, niet meer kunnen, ng a ntuk - slaperig, a ntukna - ten slotte; - njut - een zachte beweging of een kleine ruk aan iets, gaat terug op djut, zie boven blz. 318 s. v. djot; $-\mathrm{njilu}=$ ng il u - eggig, slee, zoor, v. d. tanden. Dit woord luidt in Bat. Kar. en Bar. ngilu, in Tb., Tont., Bis., Mag., Bkl. ng ilo doch in Pmp. lin ju, Jav. 1 in u. Of nu Mal. $n \mathrm{j}$ il u een omzetting is van $\operatorname{linju}$ dan wel omgekeerd, laat zich niet uitmaken; de wisseling van $n j$ en $n g$ behoeft geen bezwaar te zijn daar zij ook in andere talen voorkomt; - n j i u r - de kokospalm, Tag. n i y u g, Maori n i, Bal. n j u h, Sas. njur, Mad. njor, Day. ěnjoh, Saleyer andjorro, in dit laatste is de slot - o steunvocaal, a n- = Indon. ěn - is voorslag, het gw. is dus djur (djor), genasaleerd beantwoordt Day. ěn joh volkomen aan het Saleyersch; $\mathrm{nj}$ i u r is een bijvorm van $\mathrm{njur}$. Ik zie een bevestiging van deze afleiding in Jav. $\mathrm{dj}$ a n u r - jong kokosblad, d.i. d j u r met infix - a n -, lett. wat tot de kokospalm gerekend wordt; - njiru, niru - zeef, wan, Day. njiro - korf, Tont. ni'u, Bis. nigo, doch Bat. Tob. anduri, met omwisseling van $i$ en $u$ (V.G. V 70), Bat. Dai. anderu, B.M., Ponos. digu, Atj. d jö'è è. De grondvorm is dus d jiru maar de genasaleerde vorm moet reeds in de grondtaal bestaan hebben daar hij zoo wijd verbreid is. Ter onderscheiding spreek ik van prenasaleering als een consonant door haar homonyme nasaal wordt voorafgegaan, van (volledige) nasaleering als de consonant in haar nasaal is opgelost.

De meeste Indonesische talen prenasaleeren thans niet meer (Maleisch, Bataksch, Soendaasch, Dayaksch, de Filippijnsche talen) zoodat aan de talen die i.c. $d$ of $d j$ hebben, niet is na te gaan of de grondtaal het woord geprenasaleerd uitsprak; in Bat. anduri kan een prenasaleering verscholen liggen, maar de $n$ kan ook bij het voorvoegsel behooren. In allen gevalle bestonden er in de grondtaal een genasaleerde uitspraak en een niet-genasaleerde, t.w. geprenasaleerd of zuiver of beiden. 
Een soortgelijk onderzoek als hier voor het Maleisch werd ingesteld, zou men ook voor andere talen kunnen ondernemen en tot hetzelfde resultaat komen. In het Soendasche woordenboek van Coolsma komen met nasaal beginnende $\mathrm{zg}$. grondwoorden, die ten rechte actieve werkwoordsvormen zijn, bij tientallen voor : $m$ ě nd ě k - iemand te voet vallen, is v. pěndĕ $\mathrm{k}$; $\mathrm{ng}$ a d o n - ergens zonder genoodigd te zijn met een bepaald doel heengaan, is van adon; $\mathrm{ng}$ a ng g r ĕs of ng a ngr ĕs - droevig aangedaan zijn, is van a n g grěs (angrĕs); njahngöj $j^{1}$ ) is omzetting van $n j a n g h \ddot{j}$, gw. sanghöj, waarvan njanghöjkön, pass. disanghö jkön - iets boven op iets hoogers leggen of steunen, bv. een krokodil op een boomstam; nalaktak - overal anzitten, is $\mathrm{v} . \mathrm{talaktak}$ enz.

Jav. ng ě $1 \mathrm{u}$ - hoofdpijn, drukkend gevoel op het hoofd, dat in verscheidene talen, ook in het Maleisch, steeds genasaleerd voorkomt, moet in de grondtaal reeds de genasaleerde uitspraak hebben gekend, cf. Samoa ngalulu (n g a lu + ulu) (V.G. V 120)

Merkwaardig is Tb. nawu, Sang. nawo, Ibg. nábu, Mak. $\mathrm{n}$ a u n $\mathrm{g}$ - vallen, neerstorten, alle deze vormen zijn sec. grondwoorden, de substantiefvorm is $\mathrm{tab} \mathrm{u}-\mathrm{ban}$, onder den ban, niet meer als zoodanig onderkend. Zie verder V.G. V 75.

Alles wijst erop dat oudtijds in het Austronesisch een wortel en een grondwoord met vóór-syllabe niet met een nasaal konden beginnen. Een zuivere wortel kon worden genasaleerd en hiervan door herhaling of reduplicatie een grondwoord worden gevormd (Hoofdstuk III), nasaleering der vóór-syllabe is tot enkele gevallen beperkt, uit prenasaleering ontstaan. Men kan zelfs verder teruggaan, tot het Austrisch, want ook de Austro-Aziatische talen bieden voorbeelden van nasaleering der vóór-syllabe: Mon. $\mathrm{mrāk}-$ pauw, Bhn. mra, doch St. brak, Indon. mĕrak. Daar $m$ niet in $b$ overgaat, moet $\mathrm{brak}$ de oudere vorm zijn en is dus $\mathrm{m}$ ĕ $\mathrm{rak}$ een genasaleerd, uit pre-nasaleering ontstaan $\mathrm{brak}$; in den wortel rak ligt de beteekenis ,een luid geluid maken”, Filippijnsche talen i y a k - schreeuwen ( $y$ beantwoord aan $r$ ), Jav. Soend. s u ra k - schreeuwen, juichen, Sul. sualak - schreeuwen ( $l=r$ elders), Soend. harak - krakeelen - voorts Mon. ǵ a blu - betel, Khm. mělūw, Bhn. bölou, St. $\mathrm{m} 1 \mathrm{u}$.

1) $\mathrm{De}$ in het $\mathrm{Wb}$. gegeven verklaring $(\mathrm{P})$ is niet juist. 
V.

\section{Prenasaleering.}

In de grondtaal moet prenasaleering van de beginconsonant of beginvocaal van een woord zeer gewoon zijn geweest. $\mathrm{Zij}$ bleek reeds uit enkele genasaleerde woorden welke wij boven noemden en die alleen uit prenasaleering te verklaren zijn. Doch er zijn meer bewijzen voor aanwezig.

Bij woorden die met een klinker aanvangen, is prenasaleering (met $n g$ ) gelijk aan nasaleering, er ontstaat een nieuwe klank: nga, ngi, enz., niet slechts een klank met een voorslag, die weer kan afvallen, zij is vast en blijvend, ook in talen die niet meer prenasaleeren. Voorbeelden: Bis. Tag. ng a la n - naam, Ibg. ng a g a n, Tont., Tb. $n g$ a r a n, Sang. a r eng, Mlg. a n a r a nă, Soemb. ng a ra, Soend. $n g$ a $r$ a $n$ en a r a n, O.-Jav. ng a ra n, ha ran, ar a n, N.-Jav. a ra n, beide uitspraken, met en zonder nasaal, moeten in de grondtaal bestaan hebben. Evenzoo: Mal. idung - neus, Jav., Soend. irung, Day. urong, Mlg. uruna, Tont., Tb. ng irung, B.M. ng i u ng, Bent. irun, Tag., Bis. ilung, Ibg., Bat. igung, Sang. irung, Soemb. urung. Samoa is u. F. u $\delta$ u - neus, landtong, kaap; Tag. ngipin - tand. Bis., B.M. ng ipon, Ibg. ng ipan, Pamp. i p a n, Sulu ipun, Tont. i p̌ng, Bat. i pon, Niasch i fö, Kisar nihin, Kei nifān, Samoa nifo, Tb. ipěn - tandvleesch; Mal., Jav., Tag., Bis. a 1 u n - golf, Samoa ngalu; - Mad. ngòwíqgeluid v. d. buffel, Soend. ow e. Alleen geprenasaleerd: Bar. ng u ra - jong, Soend. ngora, Mad. ng oda (h), Bat. Kar. ng uda, doch van den zuiveren vorm komt Mal. muda $(\mathrm{um}-+\mathrm{uda})$, Tag. mura; - Day. nupi - droomen, Soend. impi, Jav. impen (met suffix - a n), het Day. vertoont $n$ in plaats van $n g$, de wisseling van $u$ en $i$ komt in het Dajaksch meer voor.

Meermalen komen in één taal niet- en wel-geprenasaleerde vorm naast elkaar voor, bv. Soend. a ing $=\mathrm{ng}$ a ing - ik, ewa en ngewa (dipikangewa) - een afkeer hebben van; Day. kuk en ng u k - het geknor van zwijnen; Mak. a re en ngare - wellicht; a seng en ngaseng - alle; Jav. a re en ngare - laag, vlak en open land; Tont. o' a j ěm en ngo' a j ĕm - het geluid van geeuwen; Mlg. nif y en if $\mathrm{y}$ - tand. Daar de tendentie tot prenasaleeren in de afzonderlijke talen kan hebben nagewerkt, ook in die het thans niet meer doen, is bij dubbele uitspraak in een zelfde taal niet met zekerheid te zeggen of zij beiden uit de grondtaal dateeren. 
Men zou daartoe moeten weten of het woord in de grondtaal aanwezig was. Wanneer èèn taal beide vormen heeft en overigens alleen de zuivere uitspraak voorkomt, bv. Bat. Mand. utok en unok, elders ut ĕk, dan is het waarschijnlijkste dat un ok door het Bat. zelfstandig gevormd is, maar dan zou daaruit tevens volgen dat voor het taalgevoel zuivere wortel en geprenasaleerde wortel gelijkwaardig waren, dat dus hetgeen in de grondtaal gold, in de talen die haar loten waren, bleef doorwerken. Als werkhypothese kan men dus stellen: in woorden die in een enkele taal geprenasaleerd voorkomen, in afwijking van andere talen, is de prenasaleering van lateren datum. Zoo ook wanneer, een enkel maal, prenasaleering en nasaleering naast elkaar bestaan, bv. Jav. $\mathrm{m}$ bu n g en $\mathrm{m}$ ung - slechts, van een vermoedelijk zuiver w ung. Doch wanneer men vindt Soend. $\mathrm{g}$ a $\mathrm{n}=\mathrm{n} \mathrm{g}$ a $\mathrm{n}$ slechts, en het $\mathrm{F}$. toont $\mathrm{ng}$ a, dan moeten beide vormen in de grondtaal bestaan hebben, cf. Mal. d j a n g a n (V.G. V 58). - Zoo moet ook Jav. ng ělu - hoofdpijn, drukkend gevoel op het hoofd, dat in alle talen waarin het voorkomt, genasaleerd is, reeds in de grondtaal geprenasaleerd zijn geweest, de grondvorm is ě $1 \mathrm{u}$ (boven blz. 340).

Tegenover Jav. $w$ kan Soend. $t j$ staan, bv. Jav. wa ring i n, Soend. t j a ring in, Soend. t j a i, O.-Jav. wa i, enz. Men vindt echter enkele malen in het Jav. $b$. N.-Jav. vertoont wel eens $b$ waar Oud-Jav. $w$ heeft, bv. wagus - bagus, wudjuk, Soend. idem, N.-Jav. b u d j uk. Doch tegenover O.-Jav. ba h ĕm - kies, staat Soend. t ja höm - mond, bek, Mal. b a ham - kauwen met gesloten lippen, Tont. wa'ang - tand, Tag. Bis. bag ang, Bat. bor ham; O.-Jav. $\mathrm{b} a \mathrm{~h}$ ĕ $\mathrm{m}$ moet teruggaan op $\mathrm{w}$ a h ĕm en daarvan de geprenasaleerde vorm zijn, waarvan vervolgens de prenasaleering is afgevallen ( $\mathrm{m} \mathrm{ba}$ h ĕm $>$ b a h ĕm). O.-Jav. wa la ng = b a la ng - sprinkhaan, toont de beide vormen, N.-Jav. heeft alleen walang. - Van N.-Jav. b a n g k a ng - zeeschelp, Soend. t j a n g k a n g - schelp, schaal, bolster, en van N.-Jav. b a p a n g - armen zijwaarts horizontaal uitstrekkende, Soend. t j a pa n g - zijwaarts uitstaande, bv. buffelhoorns, zijn geen Oud-Jav. termen bekend; de oude uitspraak blijft dus onzeker. Doch er blijkt toch dat het Oud-Jav. een zuivere en een geprenasaleerde uitspraak van de $w$ gekend heeft.

In het Nieuw-Javaansch is de prenasaleering nog niet geheel verdwenen. $\mathrm{Er}$ is nog altijd een neiging te prenasaleeren doch het geschiedt willekeurig. Er zijn gevallen waarin de niet- en wel-genasa- 
leerde vormen naast elkaar voorkomen, bv. Oud-Jav. pu, mpu heer, andere waarin men oude prenasaleering heeft laten vallen, bv. Oud-Jav. ng kān a - daar, thans kana; nduk - toen, thans duk - ten tijde van. Daartegenover staan woorden waarin zij zeker niet oud kan zijn : $\mathrm{m}$ b ot ě n - niet, neen, voor b o t ě n, m b e s u k - morgen, voor be suk, in plaatsnamen vóór een muta: ng Gĕnding, $\mathrm{nDj}$ a p ra, nDara, mBandung. In dienstbrieven van 100 jaar geleden in 't archief van Madjakěrta vond ik steeds Antang, Awi, Rawa geschreven, ongetwijfeld overeenkomstig de toenmalige uitspraak, thans zegt men Ngantang, Ngawi, Ngrawa. $\mathrm{Ng}$ kan hier niet de prepositie ing zijn, want men spreekt de nasaal onder alle omstandigheden uit, ook in den Nominatief.

Het Gajō'sch bezit een aantal geprenasaleerde woorden, meestal éénlettergrepige woordjes: $\mathrm{ng}$ g - gaat niet door, ng ki p - boordevol, somtijds ontstaan doordat de eerste lettergreep is afgeworpen: $\mathrm{ntah}$ - drukt onzekerheid uit, Mal. ěn tah; ntang = těntang - de juiste richting; echte prenasaleering van de beginconsonant is bv. $\mathrm{ntj}$ a ra $=\mathrm{tj}$ a ra - zooals. Beide uitspraken kunnen naast elkaar staan. Naast nggö vindt men ngö (z.v.a. Mal. sudah), naast ndòh (ouderwetsch) vindt men nò - partikel van beleefde aansporing, naast mbal mal - de gesloten hand, enz., dit is geen in nasaleering overgegane prenasaleering maar moderne uitstooting van de muta na de nasaal (cf. ba mang voor ba m bang).

Het Bat. prenasaleert een enkel maal, bv. Kar. mbulu - haar. In het Fidji worden $b, d$ en $g$ steeds geprenasaleerd tot $m b, n d$, $n g g$ of $n g k$. In den tongval der bergbewoners van Viti Levu gaat volgens Gatschet (Abhandlungen philol.-hist. Classe der Kön. Sächsischen Gesellschaft der Wissenschaften III en IV, Leipzig 1860, 1873) deze regel volstrekt niet altijd door en hoort men bat i en $\mathrm{mbati}$, bitu en mbitu (V.G. IV 250). Naast met $k$ beginnende woorden staat een aantal woorden dat met $n g k$ begint (V.G. V 42 v.v.).

Uit de genoemde feiten mag besloten worden dat prenasaleering in de grondtaal zeer frequent was en dat zij naast de zuivere uitspraak der beginconsonanten en -vocalen voorkwam. 't Onderscheid was fonetisch. Bij grondwoorden die door affigeering van wortels ontstaan zijn, dus bij grondwoorden der eerste categorie, heb ik geen sporen van prenasaleering kunnen vinden. $\mathrm{Zij}$ komt bij grondwoorden der tweede categorie evenmin voor, behoudens een paar op zichzelf staande gevallen. Het Fidji heeft ngkungku + gebald, v. vuist, 
vormelijk Tag. $\mathrm{kim-kim}$. Een ander $\mathrm{ngkungku}$ is: hoef v. e. dier. Dit is een gewijzigde uitspraak van $\mathrm{k} \mathrm{u} \mathrm{k} \mathrm{u} \mathrm{-} \mathrm{nagel,} \mathrm{ten} \mathrm{einde} \mathrm{de}$ twee beteekenissen door verschil in klank te onderscheiden. In den tongval van Lau wordt voor ,hoef” ook k uku gezegd (V.G. V 62).

De gevallen waarin de prenasaleering tot nasaleering geleid heeft, zijn niet talrijk.

Wat het Maleisch betreft, zijn er boven een paar genoemd. Bij onderzoek in andere talen zijn er nog wel enkelen te verwachten, zoo beantwoordt aan Jav. w ungka 1 - steen, Soend. mung ka l; tegenover O.Jav. gan di - zeker werpwapen, staat F. ng a di - een soort v. knods; palu Indon. - hamer, Ilk. malo - houten hamer, knods; Soend. manan = batan - meer (minder) dan; Bis. mantás - knap = Bkl. pantas - wijs; Tag. nakau - stelen (men zegt $\mathrm{magnakau}$ ) is van $\mathrm{takau}$.

Welke consonanten geprenasaleerd werden, is niet met zekerheid te zeggen; voor zoover nog prenasaleering bestaat, betreft zij vooral de mutae, $k$ en $p$; het Gajō'sch gaat het verst en kent haar ook van $t, t j$ en van $s$. Ook prenasaleering van $w$ heeft zeker bestaan, evenals van $h$ : O.-Jav. ng hing - maar, slechts. De prenasaleering van klinkers was $n g$. Vermoedelijk waren $l$ en $r$ de eenige klanken die niet werden geprenasaleerd.

Niet alleen het woord, ook de syllabe, dat is dus in de grondwoorden der derde categorie de wortel-syllabe, wordt geprenasaleerd en de prenasaleering is hier over het algemeen goed bewaard omdat zij door de voorgaande lettergreep beschut werd.

In het Fidji wordt de tweede lettergreep niet geprenasaleerd, de prenasaleering is daar afgevallen met uitzondering van eenige gevallen vóór $k$, bv. 1 a $\mathrm{ng} \mathrm{k} \mathrm{a} \mathrm{-} \mathrm{wijd} \mathrm{uiteen,} \mathrm{Tb.} 1$ ĕ $\mathrm{ng} \mathrm{k} \mathrm{a} \mathrm{-} \mathrm{schaarsch,}$ zelden, Jav. la ngka - zeldzaam; s a n g ka i, woord gebruikt bij het optellen v. vaartuigen, vermoedelijk een oudere uitspraak van $\delta$ a k e - bestijgen, aan boord gaan. Tag. s a ka i, Tb. s a ke (V.G. V 68). Aangezien het woord wel wordt geprenasaleerd, zelfs in sterkere mate dan in de Indonesische talen, moet het wegvallen in de 2 de syllabe met het vocalisch worden der taal samenhangen. Er zijn echter vocalisch geworden talen, zooals het Bare'e, die prenasaleering handhaven.

In de Filippijnsche talen komt prenasaleering der 2de lettergreep algemeen voor, doch in iets mindere mate dan in de westelijke talen, bv. Tag. ha ti d, Mal. ha n ta r, O.-Jav. a tĕr, N.-Jav. a n t ĕr en a tĕr - geleiden; Tag. s a l a páng, Mal. sa ra mpang - harpoen; 
Tag. t a k ob - deksel, Mal. t a ng k u p - vast tegen elkaar gesloten; Tag. ubod - palmriet, kernhout, Mal. umbut enz. Zij schijnen dus af te stammen van een dialect der grondtaal waarin minder geprenasaleerd werd.

In een zelfde taal kan een woord met zuivere en geprenasaleerde consonant der 2de syllabe voorkomen. In zoo'n geval is de herkomst moeilijk te bepalen. 't Kan zijn dat beide uitspraken op de grondtaal teruggaan, 't is evengoed mogelijk dat de prenasaleering spontaan in de taal is ontstaan. Zoo lijkt Jav. $\mathrm{k} 1 \mathrm{ombot}-$ strootje, naast $\mathrm{k} 1 \mathrm{o}-$ b o t modern, in het Javaansch dat neiging tot prenasaleering bewaard heeft, allerminst onwaarschijnlijk. Tegenover prenasaleering in de eene taal staat zuivere uitspraak in de andere en omgekeerd.

Wanneer een woord in een reeks van talen prenasaleering der tweede syllabe toont, mag worden aangenomen dat deze op de grondtaal teruggaat, bv. g u n t in g - schaar, Tag., Bis., Bkl., Pang., O.-Jav., N.-Jav., Soend., Mad., Tb., Tont., Bar., Soemb., Mal., B.M., Boeg., Mak., Bal., Sas., Day.; pandan - Pandanus, Mal., Bat., Mlg., O.-Jav., N.-Jav., Soend., Mad., Bal., Sas., Sideisch, Soemba. Omgekeerd, als men vindt $\mathrm{Tb}$. lĕp ĕt - vouwen, en verwante vormen zonder prenasaleering in Mal., Soend., Bis., Day., Mlg., Boeg., OudJav., doch in N.-Jav. lě mpit, dan is het duidelijk dat deze vormen op een grondvorm met zuivere consonant teruggaan en de prenasaleering van het N.-Jav. waarschijnlijk modern is.

Prenasaleering van de 2de syllabe was dus in de grondtaal bekend, haar beteekenis was en is fonetisch. Dit is alles als met de beginconsonant van het woord.

Een groot verschil is het volgende. Naar wij zagen komt het slechts zelden voor dat de prenasaleering der begin-consonant van het woord in volledige nasaleering overgaat (n jiru e.d.), daarentegen begint de wortelsyllabe even vaak met de zuivere consonant als met haar nasaleering. Alle wortels, in den ruimsten zin, komen genasaleerd voor. Dit komt volkomen overeen met hetgeen in het derde hoofdstuk omtrent woorden die door herhaling en reduplicatie van wortels gevormd zijn, werd geconstateerd. nl. dat de wortels in hun nasaleeringen kunnen worden omgezet. 't Een bevestigt het ander. De omzetting van zuivere in genasaleerde consonant geschiedt niet over prenasaleering als tusschenstation maar rechtstreeks.

De Austro-Aziatische talen bieden ook voorbeelden van nasaleering der wortel-syllabe, bv. Bhn. mömang - donker, St. kömang, Bhn. St. mang - nacht, deze woorden gaan op een wortel bang 
terug, zie boven blz. 316 s.v. bĕng, mèn g; Khm. kā pōr - kalk, St. $\mathrm{k}$ ö $\mathrm{m}$ u or.

't Komt wel voor dat het verschillend klankverloop tot differentieering van beteekenis heeft geleid. Zie voor dit verschijnsel in het algemeen, V.G. IX 257. In zoo'n geval moeten beide uitspraken in de taal oud zijn.

Voorbeelden van zuivere en geprenasaleerde begin-consonant in het zelfde woord:

Mal. rukup $=$ rungkup - schuin tegen elkaar gezet, Tag. $1 \mathrm{ukob}$ - bescherming.

Mal. lega r - ruimte om zich te kunnen verroeren = lenggar - vrij in zijn bewegingen of Soend. long ge $r$ - los zitten.

Jav. at jar $=$ antjar - recht toe recht aan gaan.

Jav. a dj ir $=$ andjir - staak als merkteeken, Soend. adjir. Jav. a tĕ r = a ntĕr - geleiden, Tag. hati d, Soend. a n tör.

O.-Jav. suduk = sunduk - steken (gw.), N.-Jav. suduk iets waarmee men steekt.

Jav. puḍat $=$ puṇdat - afbetaald, Soend. pudat; Day. $\mathrm{kadut}=\mathrm{kandut}$ - bundel, Mal. ka r ung - grove zak, kan d ung zak, baarmoeder.

Jav. g ĕpang = g ĕmpang - verdelgd, te niet gegaan.

Jav. d jěblong = d j ěm blong - ingezakt, v. d. grond, Soend. d j ĕm bl o ng, openbarsten, v. d. grond; Mal. tĕbu - suikerriet, maar ba mbu.

Jav. a w ur - strooien, a mbur - zaaien i. e. kweekbed.

Soend. luse $=1$ ungse - afgemat.

Jav. ḍihin $=$ ḍinghin, uitgesproken ḍingin - eerder.

Jav. gaṭ ĕng = g a ṇț ĕng - strak.

Op dezelfde wijze vindt men ook van taal tot taal verschillen. Als voorbeeld geven wij hier een overzicht van eenige van den wortel $p$ it en varianten afgeleide grondwoorden.

In dezen wortel met varianten pat, pět ( $p o ̈ t)$, pet, put, pot ligt, afgezien v. homonymen, de beteekenis ,drukken, knijpen, ergens de hand op leggen", wat eenerzijds overgaat in ,toedekken, bedekken”, anderzijds in „omvatten, pakken, grijpen, wegnemen”. (St: p ĩ t - nemen, grijpen).

Wortel pat: Soend. rapat - goed aansluiten; Soend. 1 a mpat besmeren; Jav. kipat - een snelle beweging met hand of voet maken om iets dat eraan zit, eraf te slaan, fig. zich v. e. zaak af- 
maken; Mal. t u mpat - verstopt, v. e. holte, opgepropt vol;

Wortel pĕt (pöt): Jav. p ěpět - verstopt, gestremd, Soend. idem - vast gesloten; Jav. ḍ a p ĕt - goed tegen elkaar sluiten; Jav. 1 a m pĕt - dichten (dam, dijk); Soend. r ĕ m p ĕ t - dichtbegroeid ${ }^{1}$ ); Day. rapět - nauw aaneen, samenkleven; Soend. 1öpöt - rijst in pakjes v. pisangblad gekookt, Mal. lě p a t - kleefrijst in een blad gekookt; Bis. kapot - met de hand grijpen; Tb. empět - om het lijf slaan;

Wortel pet: Soend. t jepet - een kleinigheid wegkapen; Soend. hompet - tusschen den arm en het lijf knellen; Jav. dipet goed sluiten; Jav. s o mpet - achterbaks houden; Mal. t e pet opplakken v. e. pleister; Tb. k a mpet - leunen;

Wortel pit: Soend. pipit - met de hand plukken; kĕmpit onder den arm houden; Tb. impit - onder den arm dragen; Jav. t japit - knijpen; dĕmpit - nauw, ergens tegenaan gedrukt zitten; Mal. a pit - geklemd; dimpit - dicht opeen, op elkaar gedrongen; Day. ga pit - houtblokken tegen de kanten v. e. aan land getrokken boot opdat deze vastligt; Bat. Mand. s o m pit . nauw, eng; $\mathrm{Tb}$. a mpit - meteen meenemen;

Wortel put: Soend. kěput - geheel bedekken, geheel omringen; sumput - zich verbergen; Jav. d juput - nemen, wegnemen; a mp ut - bespringen, beslapen; Mal. liput - overstelpen, over iets heen gaan, overdekken; d j ĕm put - nijptangetje, een klein greepje v. iets nemen (met de vingers); Bug. s a m p u' - sarong; Day. k a put - dicht begroeid, donker; Tb. da p u t - kleven, plakken; zie ook blz. 326 s.v. II p u t;

Wortel pot: Soend. $t \mathrm{jĕpot} \mathrm{-} \mathrm{zich} \mathrm{vasthechten,} \mathrm{vastzuigen;}$ $\mathrm{k}$ ĕ $\mathrm{m}$ o t pi pi - kuiltjes in de wangen, lett. ingedrukt v. wangen; Jav. k ěmpot - holte, deuk; k a m pot - vijf bossen pas geoogste padi; o m pot - zich schuil houden;

Voorbeelden van den genasaleerden wortel:

mat - Mal. s ěmat - vaststeken, vastspelden, Day., Jav. idem, Soend. sömat; Jav. t u mat - gaan zitten op (P.); Tb. ri mat aanstampen, vast maken;

mĕt - Jav. a mĕt - een dracht padi, Bis. k a mot - hand, Ibg. k a mót - handvol;

$\mathrm{m}$ i t - Soend. d ěm i t - bedektelijk, zekere geesten, Mal. i k, in geheimzinnige taal; Jav. li mit - platgetrapt; Mal. ga mit - even met den vinger aanraken; Day. ka m it - grijpen;

1) De verklaring in het $\mathrm{Wb}$. is minder juist. 
$\mathrm{mut}$ - Jav. ĕmut - in den mond houden (om op te zuigen, te sabbelen); Mal. kĕmut - zich samentrekken, zich sluiten; Bat. Mand. d jĕ mu t - diefachtig;

mot - Jav. d j ĕmot $=d j$ ĕmut - wegnemen; Soend. $t$ j o mot - tusschen de vingertoppen nemen; Tont. s a mat $=$ naar zich toe strijken (halen), zóó dat er niets meer achterblijft.

Dezelfde wortel komt voor met zwakkeren eindconsonant $(k)$ :

Wortel p a k: Soend. t j ĕ pak - neerdrukken, platdrukken; r u m pa k

- loopen tegen iets, Tont. aankomen tegen; Jav. a m pa k-ampak - mist, nevel, in de bergen; Jav. Tag. enz. ta pak - spoor, voetindruk; Mal. dampak - tegen elkaar aanbonzen; Soend. dupak - bonzen tegen; Mal. kĕpak - vleugel;

Wortel pěk (pök): Soend. römpök - afsluiten; rupĕk - benauwd, beklemd, Jav. su m p ěk - idem; Day. s u pek - ingedrukt; Tont. p ě 'p ěk - bedekken ;

Wortel pek: Soend. e pek - buikband; Jav. ěpek = ěm pek nemen, wegnemen; Mal. kepek - ingedrukt; Tont. s ěpek - de vlakke hand op iets leggen;

Wortel pik: Soend. hömpik - iets nederdrukken door er wat op te leggen; Jav. ampik-a mpik - afsluiting, v. driehoekige opening aan twee zijden onder zadeldak; ěpik - wederrechtelijk iets afnemen van; Mal. kěpik - gedeukt.

Wortel p uk: Soend. i puk - zaden uitleggen (in den grond drukken); Jav. djupuk $=\mathrm{djuput} \mathrm{-} \mathrm{nemen,} \mathrm{wegnemen;} \mathrm{Mal.}$ t a mpuk - bedekking; Jav. djipuk $=d j i p i k$ - wegnemen, weghalen;

Wortel pok: Soend. popok - bedekt, bedolven; Jav. depok= d e m pok - plat op den grond zitten; Mal. e pok - taschje met deksel; rom pok - boordsel v. e. kleed;

Ook van deze reeks bestaan genasaleerde wortels:

$\mathrm{m}$ a k: Jav. $\mathrm{tj}$ ěmak - aanraken, aanvoelen; $\mathrm{d} \check{\mathrm{e}} \mathrm{mak}$ - met de hand pakken; Mal. g a m a k - g a m a k - de hand aan de kris slaan (om die een weinig uit de scheede te trekken); Tag. hamak verlagen (neerdrukken);

m ěk: Jav. di m ěk - voorzichtig met de hand pakken;

$\mathrm{mek}$ : Jav. a mek = a met - nemen; ĕmek - betasten; Tont. me'mek - iets drukken zóó dat het zacht wordt (door herhaaldelijk drukken, de herhaling van den wortel werkt hier dus als een meervoud);

$\mathrm{m} \mathrm{i} \mathrm{k}$ : geen voorbeelden; 
m uk: Jav. d j i m uk - wegnemen; Mal. t jĕ m uk - dop, v. peulvruchten;

mok: Soend. emok - zitten, v. vrouwen, in beleefde houding, het bovenlichaam rustende op den arm, de beenen zijwaarts naar achteren uitgestrekt (een neergedrukte houding); Jav. d ěm o k= děme $\mathrm{k}$ - voorzichtig met de hand pakken; $\mathrm{dj}$ ěmok $=\mathrm{dj}$ ĕ mot - wegnemen; Mal. romok - stil ineengedoken zitten.

Uit deze voorbeelden zal het duidelijk zijn dat de wortelsyllabe met zuivere en geprenasaleerde beginconsonant wordt uitgesproken, voorts dat zuivere en genasaleerde wortel gelijkwaardig zijn. Tot slot laat ik ter illustratie van het laatste nog eenige voorbeelden volgen :

BAS, MAS. Bat. Mand. $\mathrm{ta}$ ba $\mathrm{s}$ - uitgeput, $\mathrm{v}$. d. grond, $\mathrm{ta} \mathrm{m}$ a $\mathrm{s}-i d e m$; BEL, MEL. Jav. t jomel - kletsen, mopperen, Soend. terembel maar doorpraten;

RĔNG, MĔNG. Tont. lě mĕng - begraven, Tag. libing - idem; BENG, MENG. Jav. ta men $\mathrm{g}$ - schild, t e b e n $\mathrm{g}$ - beschutting, scherm; BĔR, MĔR. Tb. r u m ěr - zitten, r u r u m ĕr, Tond. r ĕ r u m b ĕ r - de billen, F. rubu (rubo) - the seat, dij;

BI, ME. Soend. Jav. bibi - tante of behuwdtante, jonger dan vader of moeder, Mal. tante, Sang. m e me - moeders jongere zuster; Bu, mu. Sam. namu, na na $m u$ - reuk, geuren, Jav. a mbu - reuk; BUK, MUK (WUK). Mal. mabuk - dronken, a muk - amok maken, de vorm is actief maar is thans gw., de grondbeteekenis van beide woorden is dezelfde, want in $\mathrm{buk}=\mathrm{muk}$, O.-Jav. w ū k, ligt de beteekenis ,hard slaan, woedend aanvallen”, Mad. (ng) abhuk schuimbekken, van woede;

I DANG, NANG. Jav. pa ḍ ang - licht, Gaj. sidang - helder, opgeklaard, Jav, kunang-kunang - vuurvlieg, Soend. ba r a n a n $\mathrm{g}$ - schijnen, glinsteren, n j e nang - schitteren;

II. DANG, NANG. Soend. malandang - de persoon die het ud junga n (schermspel) leidt, Jav. la nang - man, mannelijk; DĔK, NĔK. Soend. $t \mathrm{j}$ i n ěn ěk - verkorten, $t \mathrm{j}$ i n d ĕk - in het kort; DӖT, NĚт. Tb. pěnět - sluiten, F. b́onot-a - afsluiten, Soend. pöndöt - sluiten;

DENG, NENG. Soend. kel e n e n g - klingelen, g a n de n g - geraas makende;

DIS, NIS. Jav. a n is - weg, verdwenen, Soend. 1ĕ di s - schoon op;

D1. 102. 
DONG, Nong. Soend. t e t e n o ng - soort mand, e n d o n g - knapzak, gend ong - soort mand;

Dos, Nos. Jav. blonos = blondos - kaal, berooid; DUNG, NUNG. Tag. 1 ind ong - beschutting, Bis. la nd o n g - schaduw, Ilk. 1 in ong - schaduw, Soend. sa 1 in d u ng - schuilen;

DJEng, NJENG. Soend. běn j e n g - zacht a. iets trekken, a n d j e n g wrikken;

DJET, NJEt. Jav. p e n j e t - plat drukken, p e d j e t - hard knijpen, indrukken;

GA, NGA. F. ranga - hoog, Maori ranga, Sam. 1 a ng a - opheffen, Soend. t a nggah - omhoog zien, het hoofd opheffen, Soemb. d j a n g g a - hoog;

GAH, NGAH. Soend. dangah - houding waarbij hoofd en bovenlijf rechtop gehouden worden, $\mathrm{t}$ a $\mathrm{ng} \mathrm{g}$ a h - opwaarts zien;

GAS, NGAS. Jav. a ng a s - weifelen, wankelen, v. moed, g a g a s - ontroeren, door een gedachte gekweld ( $\mathrm{k} \mathrm{a} \mathrm{g} \mathrm{a} \mathrm{g} \mathrm{a} \mathrm{s);}$

I. Gat, NGat. Bat. Mand. ragat - heel erg, meer dan gewoon, $\mathrm{r}$ a ng a $\mathrm{t}$ - erg, bovenmate, sa g a $\mathrm{t}=\mathrm{s}$ a ng a $\mathrm{t}$ - idem;

II. GAT, NGAT. Soend. pěg a t - knappen, afbreken, r ěn g a t - barsten, scheuren;

GĔS, NGĔS. Soend. pi n g g ěs - knakken, knappen, rĕng ěs - oud hout uitkappen;

GIS, NGIS. Soend. in g g i s - beangst, g i g is - vervaard, bang, Indon. t a ng i s - weenen(?), Jav. b ěng is - nijdig (= bewogen in ongunstigen zin), Soend. lĕngis - ontroerd; puringis - er bevreesd uitzien;

GOR, NGOR. Jav. b ĕg o r - het geluid v. h. slaan op een bekken of v. h. brullend geluid v. e. reus, Soend. s ěng or - snauwen;

GUL, NGUL. Jav. dĕng ul - overeind komen te staan, zich vertoonen, Soend. t ung g u 1 - omhoog rijzen, v. e. heuvel;

GUNG, NGUNG. Jav. b a n g u n g u $\mathrm{ng}$ - brommen, Soend. g ung, u.b. vóór: de gong werd geslagen, d ěg u n g - stel hangende bekkens; GUR, NGUR. Jav. a n g u r - liever, Soend. a n g g u r - idem; GUS, NGUS. Bis. pu n g ó s - band om haar op te binden, Ilk. pung g o s iets met een band vastbinden;

GUT, NGUT. De beteekenis van den wortel $\mathrm{g} u \mathrm{t}$ is : ,een rukkende beweging maken", de afleidingen loopen nogal uiteen. Mal. ung g u t - met een ruk aan iets trekken, ang g u t - stampen, v. e. schip, s ĕnggut - knikkebollen, angut (mangangut s.v. ngangut) - mommelen, rěngut en rungut - pruttelen, brommen, 
mopperen, van sungut: běrsungut-sungut - idem, ook: mompelen, Soend. sung u t - mond, Soend., Jav. a ng g u t - zich vóór- en achterover buigen, met het hoofd;

HAH, NGAH, HOH, NGOH. Soend. ha r ung a h ha reng oh $=$ ha r u ha h

ha re hoh - hijgen;

JAK, NJAK. Day. a $\mathrm{njak}=\mathrm{a}$ ja $\mathrm{k}$ - volgen, achternagaan;

JANG, NJANG. Day. ma n ja n g - bloemtros van kokos- en pinangpalm, Jav. ma ja n g - bloemtros van de pinangpalm;

KAL, NGAL. Jav. banga 1 - weerspannig, dangka 1 - weerbarstig, eigenzinnig, Mal. nak a 1 - ondeugend, baldadig;

KAR, NGAR. Soend. a n g a r - schraal, v. e. sawah, t j ĕng ka r - idem; KAS, NGAS. Jav. bung kas $=$ bunga $\mathrm{s}=\mathrm{w}$ ĕka s - einde;

Kat, NGat. Jav. d j ĕng a $\mathrm{t}$ - het hoofd opheffen, Soend. $\mathrm{t} j \mathrm{ĕn} g \mathrm{~kat}$ - idem;

KĔR, NGĔR. Jav. s in g ĕ r - bekwaam, bedreven, handig en vlug, Soend. a n g k ĕ r - vurig, vlug v. geest, opgewekt;

KIR, NGIR. Jav. da ng i r - omgewerkt, losgemaakt, d j ungkir onderste boven;

KIS, NGIS. Day. mang k is - schreeuwen, juichen, Indon. t a $\mathrm{ng}$ is - weenen, behoort hier of bij gis, boven blz. 354. De wortels kis en $g$ i s zijn verwant.

кон, кGон. Soend. lengoh - onbevracht, niets bij zich hebbende, kongkoh - afzonderlijk, op zichzelf ;

$\mathrm{KU}$, NGU. Jav. sangu - teerkost voor de reis, F. $\delta$ a ngk u (of $\delta \mathrm{anggu}$ - iets wat men vrienden aanbiedt bij hun vertrek; KUK, NGUK. Soend. b ěk u k = b ěng u k - met krommen neus; KUNG, NGUNG. Soend. ng ung - geruisch in het oor, kung - geluid v. e. kleine gong;

KUT, NGUT. Soend. kukut - van jongsaf als het zijne aannemen, mensch of dier, a nak kukut - geadopteerd kind, Mal. pungut - oprapen, inzamelen, a na k p un g ut, vondeling;

paI (Paj), MaI. Day. kima i - wenken, Iwt. pa j pa j - idem, Soend. g u p a j - idem, enz. Vgl. boven blz. 304.

PAK, MAK. Jav. dala makan - voetzool, Jav., Mal. ta lapakan, Soend. ta la pak, Tag. t a 1 a mpak - idem;

PANG, MANG. Soend. sĕmang - bezorgd, s a lĕmpang - bezorgd, zorgwekkend;

PAR, Mar. Soend. sa limar - zitbank i. e. prauw, Jav. dampar laag tafeltje, bankje; 
PAS, MAS. Mal. ramas - kneden, Soend. ha mpa s - uitgeperste substantie, Mal. a mpas - drab, bezinksel;

PES, MEs. Soend. děmes - een platten neus hebben, dĕmpes - laag bij den grond wegschuilend;

PUD, MUD. Soend. 1 a m u d, vlies, 1 a $\mathrm{m} \mathrm{p} \mathrm{u} \mathrm{d} \mathrm{-} \mathrm{met} \mathrm{een} \mathrm{laag} \mathrm{bedekken;}$ PUNG, MUNG. Soend. mala $\mathrm{ngmang}$ mulungmung - geheel onwetend, v. niets afweten, wortel $\mathrm{mung}$; malang pang $\mathrm{mulung} \mathrm{pung}$, Wb. idem, is de actieve vorm van pal a n g p a ng pulung pung, wortel pung. Malangmang is herhaling met klinkerverandering van mulungmung, doch de genasaleerde vorm mang van wortel pang komt in dezelfde beteekenis als pung voor, Tag., Pmp., Bik. mang mang - dwaas, onwetend; REH, NEH. Soend. sa neh - zacht, minzaam, sa reh - zachtmoedig, minzaam; s a n e h beantwoordt aan sadeh, welke uitspraak dus in de grondtaal naast $\mathrm{s}$ a r e h bestaan moet hebben, zie over de wisseling van $d$ (palataal) en $r$, boven blz. 327 .

SANG, NANG. Soend. 1 e $\mathrm{n}$ a $\mathrm{ng}=$ schoon, rein, le sa $\mathrm{ng}$, glad;

ŚEH, NEH. Soend. a ne h - eigenaardig, ge seh -- verschillend, afwijkend;

SĔK, NĔK. Jav. b u n ě k - zich beklemd, benauwd gevoelen, s ě s ĕk nauw, klemmend;

TAL, NAL. Day. $k$ in a 1 - prop v. kokosvezel op een geweer of kanon, Jav., Mal., Soend. ěn a 1 - prop op een vuurwapen, Jav. enz. ta ta 1 - spaander, Tag. idem - spaander, splinter, Sas. idem - gespouwen en daarna platgeklopte bamboe tot beschot; ĕ n a 1, k i n a 1 zijn van andere projectielen op moderne vuurwapens overgebracht;

TӖK, NӖK. Bat. Mand. u tok - hersenen, merg v. beenderen, u n o k - merg of binnenste v. stengels enz., Jav. u t ĕk - hersenen, Boeg. u t ĕ ' - merg;

TĔR, NĔR. Tag. ki n i g - beven, Jav. g ĕt ě r - trillen; TIK, NIK. Jav. ba lĕnika n - bij kleine deelen, p lĕ n i k - spikkel, țik - tik, Soend. sa ötik - een weinig, lötik - klein;

ток, Nок. Soend. montok - er flink uitzien, denok - er knap uitzien;

TU, NU. Jav. b a n o n - baksteen, w a t u - steen; b a n o n beantwoordt aan w a t o n - steenachtige grond, al wat tot hechtheid om iets gemaakt is;

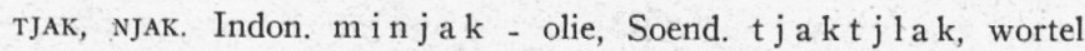
t j a k, - druppel. Onzeker; 
TJANG, NJANG. Soend. k ĕ n j a n g - aanhalen, aantrekken, k e n t j a n g - strak, stijf aangehaald;

In $\mathrm{t} j \mathrm{ar}$ en varianten ligt de beteekenis ,ergens uitspruiten, uitstorten, vooral van vloeistoffen, met als gevolg verspreiding, oplossing ;

TJAR, NJAR. Soend. bĕnt ja r - uiteenspringen, uiteenbarsten, zich verspreiden, aan gruis vallen, Jav. $\mathrm{u} \mathrm{n} \mathrm{j} \mathrm{a} \mathrm{r} \mathrm{-} \mathrm{in} \mathrm{de} \mathrm{hoogte} \mathrm{spuiten,}$ v. water, Mal. pa n t j a r - met een straal uitspuiten, Bat. Mand. h a n t j a r - diarrhee, Bat. Mand. a n j a r - verspreid door elkaar liggende ;

TJĔR, NJĔR. Soend. t jĕr, u.b. vóór: vloeien, v. e. vloeistof, Jav. $\mathrm{k}$ ĕ $\mathrm{j}$ j $\mathrm{e} \mathrm{r}$ - vocht door persing uit en in iets druppelen, Bal. b a n j ĕ h - etter, lijkvocht;

TJER, NJer. Soend. t je r, u.b. vóór: kiih - wateren, Mal. t jet jer uitstorten bij kleine hoeveelheden, Jav. k et je r - bij kleine hoeveelheden hier en daar vallen, een weinig gestrooid of gestort, Day. b u n j e r - gruis;

тЈӧн, кјӧн. Soend. k a n t jö h - instorten, v. e. zieke, ö n jö h - op instorten staan, neerstorten. Cf. Boeg. ta'n $\mathrm{junju}$ - vooroverhellen ;

тנек, NJek. Jav. be n jek - zacht, pappig, Soend. be t jek - week, modderig ;

TJuk, nנuk. Day. pun j ok - punt, spits, Jav. put j u k - idem; WAH, ман. O.-Jav. $\mathrm{d}$ j $\breve{\mathrm{m}} \mathrm{ah}=\mathrm{dj}$ ĕwa_h - gevolg, tengevolge, Mal. d j ĕ m a h - later, hiernamaals, ooit.

De resultaten van het onderzoek kunnen als volgt worden samengevat:

I. Formatieven welke afleidingen vormen of vormden van grondwoorden, dienden in een ouder stadium der taal op dezelfde wijze om afleidingen van wortels te maken; deze afleidingen zijn thans als regel grondwoorden.

II. Wortels en hun nasaleeringen zijn gelijkwaardig; er bestaan geen nasaleeringen van $r$ en $l$.

III. In de grondtaal bestond tweeërlei uitspraak van de beginklanken van een woord. Met behulp van affixen van wortels afgeleide woorden en woorden die door herhaling of reduplicatie van een wortel waren gevormd, waren hiervan uitgesloten (1e en 2e categorie). 't Verschil in uitspraak was een fonetisch verschil. De klanken $r$ en $l$ werden niet geprenasaleerd. 
IV. De beginconsonant van een wortel welke de tweede syllabe van een grondwoord uitmaakt, d.z. de grondwoorden der 3e categorie, kwam ook geprenasaleerd en, op grond van II, genasaleerd voor, wederom met uitzondering van $l$ en $r$, in beginsel zonder onderscheid in beteekenis.

Leiden, 24 Augustus 1942.

\section{NASCHRIFT.}

Nadat bovenstaand artikel geschreven was, kreeg ik kennis van het posthume werk van Dr. K. Wulff: „Über das Verhältnis des Malayo-Polynesischen zum Indo-Chonesischen" - Kopenhagen 1942 (Danske Vidensk. Selsk., Hist. fil. Meddelelser XXVII 2). De geleerde schrijver heeft zich tot taak gesteld in deze verhandeling aan te toonen, dat de Austronesische talen eenerzijds, Tai-Chineesch anderzijds in woordenschat en woordbouw zóó fundamenteel overeenkomen, dat dit slechts uit genetische verwantschap beider taalfamilies (,Sprachgruppen”) te verklaren is, m.a.w. dat zij loten zijn van één stam. Hij acht den band nauwer dan die tusschen Tai-Chineesch en Tibeto-Barmaansch, tesamen Indo-Chineesch genoemd (o.c.p. 4).

Wulff heeft een lijst van 145 woorden opgesteld, waarin op de overeenkomst van Austronesisch met Chineesch en Tai, soms ook met Tai alleen, wordt gewezen. Er is bij zoo'n lange lijst ongetwijfeld reden tot twijfel op enkele punten, doch dit tast de strekking van zijn betoog niet aan: de overeenkomst is inderdaad op overtuigende wijze aangetoond. 't Stemt weemoedig hem deswege slechts na zijn dood te kunnen eeren.

In het algemeen - over één belangrijke uitzondering komen wij beneden te spreken - staat tegenover een tweelettergrepig, Austronesisch woord in het Chineesch een mono-syllabe, welke dan met de tweede lettergreep van het Austronesische woord m.m. blijkt overeen te stemmen. Deze syllabe is in sommige gevallen de wortel, in andere niet.

Wij hebben boven gezien dat in de Austronesische talen drie categorieën van grondwoorden te onderscheiden zijn. $\mathrm{Zij}$ zijn allen in de woordenlijst vertegenwoordigd. 
1e Categorie: Austronesische grondwoorden door affigeering van wortels gevormd en hun Chineesche equivalenten.

a. Grondwoorden bestaande uit prefix + wortel.

No. 8. Oud-Jav. k a r ĕ m, Soend. k a r ĕ m [en k a l ĕ m] - zinken, gezonken, Mal., Bat. Kar., Atj. ka ram - idem, enz. - Schr. vermeldt nog Oud-Jav. k ĕ m, k ö m - in het water liggen, N.-Jav. k u m - baden, duiken in [ten rechte ,het in het water zijn, b.v. om te weeken"], Soend. kööm - onder water plaatsen [of zijn], maar dit is een andere wortel. Wortel van $\mathrm{k}$ a r ĕm is $\mathrm{r} \breve{\mathrm{m}}$, gelijk aan 1 ĕ m, r ěp, 1 ěp (V. G. IV 316, V 46), waarin de beteekenis ,in het inwendige, het binnenste, wegzinken e.d." ligt. Ka r ěm (k a l ě m) is samengesteld uit het perfectief prefix ka + wortel $\mathrm{r} \breve{\mathrm{m}}(1 \mathrm{ĕm})$.

Het Chineesch heeft ، $\gamma$ âm - onderduiken, te vergelijken met den Austronesischen wortel.

No. 70. N-Jav. ta ṇ ḍ̆s, Soend. ta nděs - in het water grond raken, op een bank of droogte blijven vastzitten, v. e. vaartuig, [Bat. Kar. t a nděs - geleund staan tegen (zie W.b.) ${ }^{1}$ ), Bat. Toba en Mand. tandos - ergens tegenaan stootende], Gayo töndös aangekomen, het eindpunt bereikt hebben. - De verder aangehaalde woorden doen niet ter zake.

Samengesteld uit prefix $\mathrm{ta}+$ geprenasaleerden wortel d ĕs, waarin de beteekenis "tegen iets aankomen, langs iets schuren”, e.d. ligt. Vgl. Soend. rinděs - gaan over iets of iemand, b.v. een rijtuig, Bat. Mand. a ndos - tegen, andos potang - tegen den avond, op iemand leggen (mangandoskon), Day. handas - iets iemand opdringen. Met verwante wortels, das: Jav. ka ṇ ḍas den ondergrond, bodem, raken, in graven, putten, stranden, vastloopen, Soend. k a nd a s - vastraken, aan den grond raken, stooten, stranden, Mal. kandas - aan den grond geraakt, op iets als een onderlaag liggen, Day. kandas - zich tegen iets wrijven; wortel dis: Jav. u dis - ergens tegen aan kruipen (insect).

Het Chineesch heeft $d^{\prime}$ ât - doorgaan, doordringen, aankomen.

Vanuit het Austronesisch bezien is niet uit te maken of Chin. ، $\gamma \mathrm{a} \mathrm{m}$ en $\mathrm{d}$ 'ât een prefix hebben gedragen. Sinologen als Karlgren en Maspéro nemen aan dat prefixen in het Chineesch hebben bestaan, doch zij verschillen van gevoelen over de vraag of op geprefi-

1) „Karo, bat. (t a n dos) - aankomen, bereiken”, is niet juist. 
geerde woorden syncope of elisie is toegepast. Karlgren meent het eerste, dus , $1 \mathrm{a} \mathrm{n}$ is ontstaan uit ouder * $\mathrm{k} 1 \mathrm{a} \mathrm{n}$, Maspéro houdt het ervoor dat elisie is toegepast: $\left.{ }^{*}{ }^{\prime} \mathrm{k} 1 \mathrm{an}>{ }{ }^{\prime} \mathrm{kan}^{1}\right)$.

De woorden welke het Chineesch met het Austronesisch gemeen heeft, zijn steeds afgekapt, op dien grond lijkt het waarschijnlijk dat het met de prefixen ook zoo gegaan is, 't is moeilijk in te zien waarom men bij prefixen een anderen weg zou hebben ingeslagen.

't Teloor gaan der prefixen makkte aan dit deel van den opbouw der taal een einde.

\section{b. Grondwoorden bestaande uit een wortel met infix.}

No. 58. Oud-Jav. 1 a m u k - bedekt, als de maan door een dunne wolk (K. B. Wb.), N.-Jav. waas, wazig, Soend. nevelachtig voor het gezicht, [Mlg. 1 a mo'kă - rot, behoort hier niet toe, evenmin momokă - rot; met Jav. la muk correspondeert Mlg. la 'mokă - vermoeid, slaperig. - Bat. Toba da $1 \mathrm{~m} \mathrm{uk}$ - murw, week, d a $1 \mathrm{mak}$ - smeren, Bat. Kar. samak - besmeren, Bat. Kar. de mak - met vuil bespat, zijn van een anderen wortel ( $\mathrm{puk}, \mathrm{pak}$ )].

$1 \mathrm{a} \mathrm{muk}$ Is met infix - a m-gevormd van wortel $1 \mathrm{uk}$, zie boven blz. 296.

Met verwanten wortel 1 ěk: Jav. u lěk - walm, wělěk - rook, warreling in de lucht.

Het Chineesch heeft $\mathrm{m}$ â $\mathrm{k}$ - voorhangsel, scherm, bedekken; $\mathrm{m}$ ĕ k - donker, stil; - met ander karakter : inkt, zwart.

Hieruit blijkt dat het Chineesche woord een brokstuk is van een ouderen vorm, door afwerping van de eerste syllabe ontstaan; het gaat terug op een oorspronkelijk door infigeering tweelettergrepig gemaakten wortel. Doch door de wijze waarop het archaisch-Chineesche woord ${ }^{2}$ ) tot een mono-syllabe is teruggebracht, waarbij een deel van het infix is behouden; is het verband met het Austronesisch verbroken en heeft het infix opgehouden formatief te zijn. Het kan in archaisch-Chineesch niet een enkele consonant zijn geweest. Immers, boven (hoofdstuk II) is gebleken dat het infix - um-, van -a m-, - $\mathrm{im}$ - en - ĕm-onderscheiden is, het is dus steeds vocaal $+\mathrm{m}$. Wij weten niet door welken klank in archaisch-Chineesch de Austro-

1) K. Wulff, Chinesisch und Tai p. 8 v.v. (Dansk Vidensk. Selsk., Hist. fil. Meddelelser XX 3) - Kopenhagen 1934.

2) Onder ,archaisch-Chineesch" wordt hier uitsluitend het Austronesische bestanddeel van het pre-Chineesch begrepen, ik geef den naam voor beter. 
nesische $l$ van 1 a m u k gerepresenteerd werd, er is geen reden een anderen klank aan te nemen, in allen gevalle moet hij op denzelfden klank teruggaan, aangezien hij deel van den wortel uitmaakte en de gelijke beteekenis uit de gelijkheid of de gelijkwaardigheid van wortel voortvloeit.

No. 59. Mal. fum ut - kroos, mos, schimmel, Soend., Bat. Mand, Gayo, Ilk., Pmp., Bis. idem, Mlg. 1 o m ot ră, Bkl. 1 o m o t. [Hiertoe behooren wel de aangehaalde woorden Bat. Toba $1 \mathrm{imut}=$ Bat. Mand. $1 \mathrm{umut}$, ook Day. $1 \mathrm{imut}=1 \mathrm{omot}$, Pol. $1 \mathrm{imu}$, met wijziging van den klinker (V. G. V 90), doch niet Oud-Jav. $1 \mathrm{i} \mathrm{m} \mathrm{u} \mathrm{t}$ - nevelwolk, Tag. Bis. $1 \mathrm{imot}$ - vergeten, daar men hier met een ander infix - i m-te doen heeft, evenzoo Bat. Toba la mot - week, breiig, met infix - a m-; voorts is Bat. $\mathrm{mu} \mathrm{m} \mathrm{ut}$ - bedorven, versleten, van wortel but, zie boven blz. 317 en Soend. t ja r e mot - vuil, besmet (niet alleen van het gezicht) van een wortel pot].

Chin. $\mathrm{mu}$ ât - zwak van oogen, kleurenblind, Tai noir $\mathrm{m} \overline{\mathrm{u}} \mathrm{t}$ enz. - donker, wordt door Wulff met Austronesisch $1 \mathrm{umut}$ gelijkgesteld. Mocht dit juist zijn - zeker lijkt het niet daar de beteekenissen elkaar niet dekken - dan ware dit een tweede voorbeeld van afwerping der 1e lettergreep met een deel van een infix, want Austro-

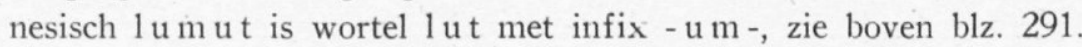

No. 23. Mak. ma e - herwaarts (gaan), derwaarts (gaan), Boeg. ma i - herwaarts, Ibg. u m a y - gaan, komen, Favorl. ma i - komen. [Tont. a i - herwaarts, is niet een valsche stam, zooals Wulff meent, maer inderdaad de stam, het infix - $\mathrm{um}$ - is vóór een klinker prefix, waarbij $u$ meestal afvalt, Ibg. heeft den volledigen vorm. Vgl. nog F. ma i - komen, vóór aanvullend werkw.; herwaarts, zoo het op een werkwoord volgt, $\mathrm{Tb}$. a i - komen, hierheen -waarts].

De afleiding blijft door wegvallen van $u$ éénlettergrepig en wordt vandaar juist zoo in het Chineesch teruggevonden: $m$ " $\bar{a} \mathrm{i}$ ' - reizen, voorbijgegaan, overtreffen.

No. 24. Bis. t in a y - ingewanden [ook Ibg. s in a y behoort hier toe], Tont. tin a'i - buik [ook: ingewanden], Mlg. tsin a i - ingewanden, [Day. kanai, knai - buik, is anders samengesteld].

Met infix - in - afgeleid van tay (ta i) - faeces, Tont. gaat, blijkens de hamza, op den nevenvorm ta hi terug. Wulff noemt deze afleiding, maar acht haar onwaarschijnlijk, zij laat zich echter geheel 
uit het infix verklaren, zie voor soortgelijke afleidingen in het Tag. en elders, boven blz. 341 vv.

Het Chineesch heeft $\mathrm{nuâ} \mathrm{i}^{\prime}$ inwendig. Vgl. voor de beteekenis: Jav. d j ĕr oa n - ingewanden, van d j ĕro - binnenin.

No. 131. Oud-Jav. kalung - halsketen, omhangen, enz. Schr. wijst erop dat dit woord met het infix - a 1 - van een zeer verbreiden wortel kung is afgeleid. Daarin ligt de beteekenis „,boogsgewijze, gekromd", vgl. boven blz. 306 .

Het Chineesch , $1 \mathrm{u} \dot{\mathrm{n}}$ - halster, is weder door afkapping der !e syllabe en met verbreking van het infix tot een mono-syllabe gereduceerd.

No. 129. Oud-Jav., Soend. kurung - kooi, opsluiten, enz.; van denzelfden wortel met infix - $\mathrm{ur}$-.

Chineesch , $1 \mathrm{u} \dot{\mathrm{n}}$ - kooi, traliewerk, is weder de 2de syllabe, $r$ en $l$ vallen in het Chineesch samen in $l$.

No. 130. Oud-Jav. gurung gurungan - strot, Tag. golong golongan, Pmp. gulung gulungan - keel, Pol. koro-koro - hals, keel (waarschijnlijk, W.) [Soend. g ĕng g ĕr o ng - keel, vertoont een ander infix en ook de wortel is wel verwant, maar niet dezelfde].

Afgeleid met infix - u r- (Filippijnsch - u1-) van een wortel g u n g, beteekennende ,gedraaid, krul, om en om”, zie uitvoerig, beneden blz. 367 .

Chineesch ،1 ù - keel, op dezelfde wijze ontstaan als No. 129.

Men ziet uit deze voorbeelden dat de in de Austronesische talen bij wortels voorkomende infixen: vocaal $+m$, vocaal $+n$, vocaal +1 , vocaal $+r$ ook in archaisch-Chineesch bestonden. $Z$ ij vielen aan het mono-syllabisme ten offer.

\section{2e Categorie. Austronesische grondwoorden door herhaling of} reduplicatie van een wortel gevormd.

In de Woordenlijst komt een aanmerkelijk aantal van zulke woorden voor. Daartegenover moet het Chineesche woord aan den enkelen wortel gelijk zijn, er is, van Austronesische zijde bezien, niet aan vast te stellen of het herhaald dan wel geredupliceerd is geweest: 
O.-Jav. ka ng kang - bestendig, Chin. „kân - hard, vast, duurzaam, enz.

$\mathrm{Er}$ is een omstandigheid die voor de waarschijnlijkheid pleit en dat is deze dat in het Chineesch ook een genasaleerde wortel optreedt, terwijl bekend is (boven hoofdstuk III) dat grondwoorden der $2 \mathrm{e}$ categorie door herhaling van den zuiveren èn van den genasaleerden wortel gevormd kunnen worden.

No. 4. Chin. ni iet - bijten, knagen $<$ ni iat. Dit beantwoordit aan een Austronesisch grondwoord dat door herhaling van ngit, genasaleerden vorm van wortel $\mathrm{g}$ it gevormd is, zie hiervoor boven blz. 321 s.v. g it.

3e Categorie. Austronesische grondwoorden uit een wortel met vóór-syllabe bestaande.

Hiervan geldt hetzelfde als van de woorden der $2 \mathrm{e}$ categorie, dat aan het Chineesche woord, gelijk aan de 2e syllabe van het Austronesische grondwoord, niet te zien is of er een vóór-syllabe is afgevallen; tegenover wortel met vóór-syllabe komt dus de Chineesche mono-syllabe $=$ wortel te staan.

De woorden dezer categorie bestaan veelal uit vóór-syllabe + genasaleerden wortel, zie boven hoofdstuk V. Wanneer in zoo'n geval het woord met een Chineesche mono-syllabe, welke met den nasaal aanvangt, correspondeert, kan men veilig aannemen, dat dit laatste ook een vóór-syllabe heeft gehad. Omgekeerd, toont het Austronesische woord een zuiveren wortel, dan heeft het Chineesche woord dien ook, b.v. No. 1 Oud-Jav. i kět - binden, Chin. ki et - binden, knoopen.

Voorbeelden van genasaleerde wortels:

No. 60. Oud-Jav. $1 \mathrm{i}$ m u n - donker, onduidelijk, N.-Jav. nevel, Bat. Kar. niet recht zichtbaar, Soend. ha lim un - nevel [ha is een oud voorvoegsel, naww verwant aan ba, thans nog levend in het Dayaksch, de beteekenis is possessief], Mal., Bat. Toba hal im u n a n - naam van een onzichtbaar makend middel [Bat. Mand. - naam van een duisterniswekkend formulier, ook in het Soendaasch is (a dji) halimunan een spreuk die den prevelaar voor anderen onzichtbaar maakt], Bat. Toba le mu n - verhelen, loochenen, Bat. Kar. himun - nog donker maar reeds een beetje gaande dagen, Bat. Toba samon - nevel. [Bat. Toba Mand. lamun - rijp, van 
vruchten, 1 a m u n 1 a m u n - bleek van gezicht, behooren niet hier; mon mon - snot, is van een anderen wortel, zie blz. 325].

Het Chineesch heeft 'muân $<\mathrm{mw}$ ân - vertroebeld v. gezicht, verhelen; ، $\mathrm{mị} \mathrm{ĕn} \mathrm{-} \mathrm{herfsthemel,} \mathrm{treurig,} \mathrm{droevig.}$

m un Is genasaleerde wortel bun (w un), cf. Jav. ĕbun - dauw, mist, Soend. ibun - dauw, morgennevel, Mal. ĕmbun - dauw, nevel, r a bun - rook, v. e. geneesmiddel, Soend. raw un - allerlei dingen die een stinkenden rook teweegbrengen verbranden om geesten of ongedierte te verdrijven, Day. ambon - dauw, nevel, Oud-Jav. aw un - aw un - nevel, Bis. gabun - damp, doom, Tb. awun rook, damp, Tag. a mbun - fijne regen.

No. 63. Oud-Jav. r ĕmöng, - bewolkte lucht, wolken, N.-Jav. r ĕm ĕn g - schemering, schemerig, beneveld, door de wolken bedekt, van de maan, Soend. dampig, wazig, donker [in deze beteekenissen in beide talen steeds herhaald], Mal. r ěmang - schemerig, triest, Mak. r a mmang - wolk, Boeg. r ĕ mmang - idem, Ilk. le m meng - verborgen plaats, Soend. m ělěng měng - onduidelijk, niet zichtbaar in de details, iets als in een nevel zien.

De wortel is bĕng, zie boven blz. 316 .

Chin. ‘mùn - nevel, regen; met ander karakter: donker, triest; ‘m i è - donker, triest, nevelig.

[Van deze woorden zijn te scheiden: Soend. malangmangmulungmung - onwetend, Tag., Pmp. [ook Bkl., Png.] mang mang - dom, vergeetachtig, zij zijn van de wortels pang, pung, boven blz. 356. De Chineesche verwanten zijn ، $\mathrm{mu} \dot{\mathrm{n}}<\mathrm{mu} \dot{\mathrm{n}}-$ dom, 'mie $\dot{n}<$ mie $\dot{n}-$ onwetend. In het Chineesch zijn de woorden door elkaar geloopen.

Ook de Austro-aziatische talen vertoonen den genasaleerden vorm: St. kömang - donker, mang - zwart, Bhn. mömang - donker, mang - nacht $\left.{ }^{1}\right)$.

In de tot nu besproken gevallen stond steeds tegenover een tweelettergrepig Austronesisch een éénlettergepig Chineesch woord, met afwerping van de eerste lettergreep van het Austronesische woord, gelijk aan de tweede daarvan. Hierop bestaat één groote uitzondering: wanneer n.1. de $2 \mathrm{e}$ lettergreep aanvangt met $h, y(j)$ of $w$

1) P. W. Schmidt S. V.D., Grundzüge einer Lautlehre der Mon-Khmer Sprachen blz. 71 - Weenen 1905. 
wordt in het Chineesch de 1e lettergreep niet afgeworpen, maar heeft er samentrekking tot één syllabe plaats, dus Mal. djahit - naaien, Chin. t'üät - tesamennaaien, verbinden; Mal. siyap - gereed, klaar, Chin. si e p - overeenstemming, harmonie, aanpassen, tesamen; Oud-Jav. bwang - opjagen, wegslingeren, wegwerpen, Mal. bu wang, Chin. püa ń ' loslaten, laten gaan, ontslaan, wegzenden, verbannen. De woorden van deze soort vormen ruim $1 / 5$ van de geheele lijst. Zij zijn dus in archaisch-Chineesch tweelettergrepig geweest. Verscheidene ervan bestaan uit een van een infix voorzienen wortel, zooals Wulff terecht opmerkt, de aard dezer infixen dient echter nog nader te worden onderzocht.

In de volgende gevallen bestaat het woord zeker uit een wortel met vóór-syllabe, t.w.

No. 30. Oud-Jav. puhun - oorsprong, het eerste, Mal. pohon - boom, oorsprong, oorzaak, enz., Tag. p u h u n a n - principaal, kapitaal, enz.

[Van denzelfden wortel: ruhun gw. van Jav. rumuhun vroeger, Soend. karuhun - de voorouders, a dat buhun - oude adat, Tag. a hon - uitgang, opgang. - Varianten zijn: hin, Jav. dihin, rihin - vroeger, vooraf; han, Soend. bahan - iets voor iets, stof tot iets, Jav. bouwstoffen, Soend. la ha n - stuk grond waarop iets verbouwd zal worden. In h u n en varianten ligt dus de beteekenis ,begin, oorsprong”. Het Chineesch luidt “p u ĕn < pwěn.

No. 41. Bat. Toba ri j a k- schertsen [Bat. Mand. luidkeels lachen, Bat. Kar. golven, brekers aan het strand], Bat. Toba turijak luide lachen, Mak. riya' - opschudding maken, Ilk. riak - luid spreken [Soend. rijak - rochel], Siam. riek' - aanroepen, aanspreken, noemen, Tho ri a k ${ }^{\prime}$ - aanroepen, noemen; Mal. tĕri ja k - roepen, schreeuwen, is t ě $+\mathrm{rij}$ a k of t $\breve{r}+\mathrm{ijak}$, cf. Tag., Bis. Pmp., Bkl. i y ák - schreeuwen, schreien; Pmp. ga li y ak - schreeuwen, sec. gw. van gi yak, Jav. gi jak - gejuich, Soend. kejak . schreeuw (vogel).

De wortel jak $=\mathrm{rak}$; $j$ en $r$ (beide $r$ 's) is een bekende wisseling in de Austronesische talen; in het B.M. wisselen $j$ en $r$ zeer gemakkelijk en komen zij naast elkaar voor, b.v. dajag = da rag - geel; jojok $=$ rorok - inproppen, enz. ${ }^{1}$; Tont. $\mathrm{kajot}=\mathrm{karot}$ schrap; Soend. $1 \mathrm{umpujuk}=1 \mathrm{umpuruk}$ - ineenzakken; Tag. d a y a $\mathrm{mi}=$ Soend., Mal. d ja ra m i - padistroo, padistoppel; Tag., 
Bis., Ibg., B.M. ugat, Lamp. oya, Gajo u jöt, Pmp. uyát, Jav. o j o d, het woord omvat de beteekenissen ,,ader, spier, vezel, zenuw, wortel"; Tag. pug ò, Mal. Jav. pu j u h - kwartel. - De gutturale $r$ gaat in Pmp., Gajo, Lamp. als regel in $j$ over (als slotklank $i$ ) b.v. Mal. para u - heesch, Tag. paga u, Pmp. pay a u (payo), Gajo pa jo; Tag. gamut - wortel, Pmp. ya mút; Mal. ekor - staart,

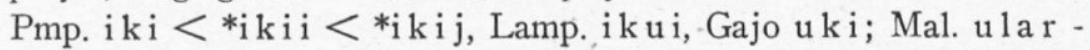
slang (= Jav. ulĕr), Lamp. ula i.

Met wortel rak zijn gevormd: surak - schreeuwen, juichen (Indon.), Oud-Jav. k ě r a k - geraas maken, schreeuwen, Boeg. k ĕ r r a' - schreeuwen, Austron. mĕrak - pauw, naar zijn schreeuw.

Varianten zijn: rek, Soend. berek - leven maken, kerek snorken; r i k, Soend. t j ö r i k - schreien, B.M. k u r i k - gillen, Soend. ta rik - snel, vlug, doch ook hard, van geluid; ruk, Soend. dě dĕr uk - soort tortelduif, naar haar gekoer, Mal. d ĕ r oek - dof krakend geluid; rok, Soend. korok - snurken.

$\mathrm{Nu}$ de verwantschap der Austronesische talen en het Chineesch door Wulff is aangetoond, is het gewettigd ook Tai in het onderzoek te betrekken. Ik meen dat niet beter te kunnen doen dan door hem zelf aan het woord te laten. In zijn verhandeling: „Chinesisch und Tai” zegt hij o.a. het volgende: „Het Siameesch kent wortelwoorden met en ,,zonder infix $r$ en $l$, b.v. $\mathrm{krik}^{\sim}$ - tikken, $\mathrm{kik}^{\sim}$ - tikken, gichelen;

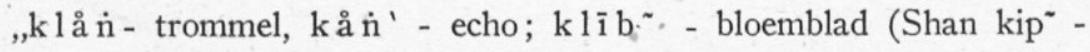
,uieschil), kī b : - hoef, vgl. kā b - schoep, scheede, bloemblad, Chin. k a p - beschuttend omhulsel, schoep, - - 2)" [Vgl. Austron. wortel k a p, k a b waarin de beteekenis ,omvatten” ligt.]

Het Siameesch bezit zulke wortels zonder nevenvorm met infix, met nevenvorm, ook wel alleen met infix. Geheel hetzelfde verschijnsel doet zich bij de Soendasche umpak basa voor (deze Bijdragen dl. 102, blz. 81 v.v.). De overeenkomst gaat nog verder. In het Siameesch worden beginconsonant van den wortel en geinfigeerde $l$ [of $r$ ] somtijds door een vocaal gescheiden - in het algemeen geschiedt dit na palatalen en dentalen vóór $l$ - 't Soendaasch toont dezelfde neiging, of liever ongeneigdheid twee-consonanten op elkaar

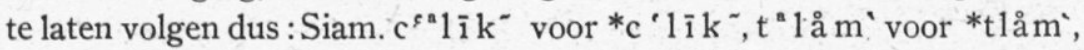
ook $s^{*} 1 \mathrm{ak}^{\sim}$ voor $* \mathrm{~s} 1 \mathrm{ak}, \mathrm{d}^{* \mathrm{n}} 1 \mathrm{u}$ ọ ñ voor $* \mathrm{~d}^{`} 1 \mathrm{u}$ ọ $\dot{\mathrm{n}}$; Soend. bara 1

1) Dunnebier, Spraakkunst van het Bolaang Mongondowsch, Bijdragen Kon. Inst. 85 blz. 308 .

2) o.c.p. 193 v.v. 
voor bral, pĕrak voor prak, djilig voor djlig. Vgl. nog Siam. b'rā i - stralend, lichtend, b 'ue i - zonsopgang, b' ue i b 'u n - stralen, lichten, Soend. braj, u.b. vóór: tembong t jaha jan a - de glans werd zichtbaar, börang - de dag brak aan, t j a a ng het werd licht, enz., ba rabaj $=^{*}$ baj met reduplicatie en infix - a r - - lichtflikkering.

Het blijkt door vergelijking met het Siameesch ook mogelijk wortels van Austronesische woorden op te sporen. Ook hiervan een paar voorbeelden.

De wortel van Soend. pělak - planten, kan zijn lak en pak 't eerste komt niet in aanmerking, de wortel pak is o.a. aanwezig in Soend. t a pak - spoor, Jav., Soend. t umpak - zijn op iets anders, Soend. t jĕp a k - platdrukken, s ep a k - schoppen (vele talen) en vele anderen, dit alles past niet geheel voor ,planten”. Het Siameesch levert de ,missing link”, want dit heeft pak - inplanten, ergens indrijven, pl $\mathrm{uk}^{-}$- planten, inplanten, oprichten ${ }^{1}$ ), Soend. pĕlak is dus van wortel $\mathrm{pak}$ en merkwaardigerwijze heeft het Soendaasch hier dezelfde beteekenis als het Siameesch, in de Austronesische talen is zij, eenigszins anders, ,ergens op drukken, ergens een indruk op nalaten", wat ook uitkomt in Soend. i p u k, met verwanten wortel, - zaden uitleggen.

Als tweede voorbeeld noem ik Jav., Soend. g u l u n g - opgerold, niet met een wortel $1 \mathrm{ung}$ in verband te brengen. Doch Siameesch heeft naast $g^{£} 1 u_{\dot{n}^{\prime}} \mathrm{g}^{\prime} 1 \mathrm{i} \dot{\mathrm{n}}^{\prime}$ - wankelen, $\mathrm{g}^{\prime} 1 \ddot{\mathrm{u}} \dot{\mathrm{n}}$ - rollen, $\mathrm{g}^{\prime} 1 \bar{o} \dot{\mathrm{n}}$ -

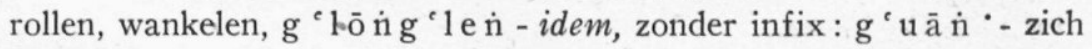

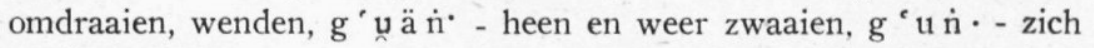
om iets winden, de wortel is dus $g^{\text {' }} \mathrm{u} \dot{\mathrm{n}}^{\cdot}$ enz. $^{2}$ ).

In de Austronesische talen bestaan nu een zeer groot aantal, door infigeering van dezen wortel afgeleide grondwoorden, bv. Jav. Soend. gulung - opgerold, Mak. oprollen, Mlg. holona, horona oprollen, Tg. golong - omdraaien, Ilk. gulung g ulung - armband, Day. ga long - bundel rotan, Bat. Mand., Kar. g a lung rol, bos, Bat. Mand. g e l u n g - ter zijde rollen, g o l u n g - oprollen; Boeg., Mak. g a l ung - sawah, d.w.z. een stuk grond waar een dijkje rond omheen loopt, zooals blijkt uit ga l ung a ng t u dang - in een vierkant of cirkel zitten, $\mathrm{g}$ a $\mathrm{l} \mathrm{u} \mathrm{ng}$ is ook een van een rand voorziene bladzijde schrift, Jav., Soend. g ěl ung - haarwrong, Mal, halve, 
cirkelvormige bocht, Boeg. g ĕl1 ung - gekruld, de beteekenis van den wortel is ,gedraaid, krul, om en om".

Verwante wortels zijn: gang, göng(g ĕng), ging, g eng, gong, bv. Jav. (g ě)gělang - armband, gěla ngan - ring, Mal. gĕlang - armband, voetring Soend. gölang - idem, Bat. Mand. golang - armband, Bat. Kar. gĕlang - armring, Boeg. gěllang - enkelring, Soend. golang wentelende, aan komende rollen, Day. gelang - padiaar, gilang - rond, gespannen omhoog staan (zonnescherm), Bat. Mand. ga la ng a n - een met rotan omvlochten flesch, g u la ng rollende, Bat. Kar. bij een steilte neerrollen, Tag. ga láng - rol, armband, katrol; - Jav. g a lĕng a n, Soend. g a 1 ĕng - sawahdijkje; beide beteekenissen, Soend. g a lĕng - de omsluiting, Boeg. galung - het omslotene, zijn vereenigd in Mal. galanggang (herhaalde wortel met infix - a 1-) dat 1. ronde vlakte, 2. kring om iets, beteekent, Soend. göröng - aardworm; - Mal. giling oprollen, door rollen malen (p a n g g i 1 i n g a n - molen), Bat. Mand. iets overrijden, fijn wrijven, met rolsteen, Soend. rol, cylinder, Day. giling - omgedraaid, tesamengerold, ga ling a n - windhaspel, Tag. giling - malen, Bat. Kar. fijn wrijven, in een mortier, Jav. guling, Soend. guguling - rolkussen, Mal. guling - rollen, Soend. galing - gekruld, Boeg. giling - draaien, guling - rollen; - Mal. g e l e n g = g i ling, Soend. omdraaien (rad), rijden over, Bat. Mand. zich wentelende; - Boeg. g olong - vastbinden, van zeilen aan een mast (eig. ze erom rollen), Soend. g olong - rol, kluwen.

Van deze woorden bestaan weer frequentatieve vormen: Soend. gereleng - rollen, kronkelen (een beek), gorolong - voortrollen, g u rul ung - voortrollen, enz.

In het begin zijner verhandeling maakt Wulff de opmerking dat de grammatische bouw van Tai-Chineesch zoo eenvoudig en ongecompliceerd is dat de grammatische overeenkomsten met de Austronesische talen daardoor veel te algemeen zijn om als bewijs te dienen (o.c. p. 5). Hij heeft zich daarom ertoe bepaald overeenkomsten in den woordenschat aan te wijzen; zooals wij reeds zeiden komt hij tot een aantal van 145 woorden die Chineesch en Austronesisch zijn.

Er blijkt echter - en de door Wulff zelf bijeengebrachte gegevens leveren daartoe de stof - dat de grammatische overeenkomst inderdaad aanwezig is. De 1e en de 3e categorie van Austronesische grond- 
woorden keeren in archaisch Chineesch terug, voor de 2e categorie is dit niet aan te toonen omdat herhaling en reduplicatie c.q. moesten afvallen, er is echter ook niets dat ertegen spreekt. De verkeerbaarheid van wortels in hun nasaleeringen is aan Austronesisch en archaisch Chineesch gemeen. Beiden komen dus zeker tot op groote hoogte, mogelijk geheel, in grammatischen bouw overeen. Uit den aard der -zaak geldt dit alleen voor het Austronesisch bestanddeel van het preChineesch.

Immers, het Chineesch bezit een veel grooter aantal woorden die niets met Austronesisch gemeen hebben. Voorts is de drift naar het mono-syllabisme niet uit de Austronesische talen te verklaren. Een en ander doet ons het Chineesch zien als een mengtaal, het pre-Chineesch heeft een Austronesisch bestanddeel in zich opgenomen, doch het is een bijstroom die zich in den hoofdstroom heeft uitgestort, elders ontsprongen. De door Wulff uitgesproken meening dat de Austronesische talen en Tai-Chineesch twee verschillende leden van één en denzelfden taalstam (,,Sprachstamm”) zijn (o.c. p. 4) kan dan ook niet worden onderschreven. Dit doet echter niets te kort aan de groote verdienste van zijn werk: de aanwezigheid van een Austronesisch bestanddeel in het Chineesch te hebben aangetoond.

De vermenging is meer geweest dan het overnemen van een aantal woorden; immers, de geheele, grammatische bouw van het Austronesisch is vertegenwoordigd, waren slechts losse woorden overgenomen, dan had dat niet het geval kunnen zijn.

't Is verder duidelijk dat het mono-syllabisme een verder doorwerken van het Austronesische deel en medewerken aan de ontwikkeling van het Chineesch heeft afgesneden. In hoeverre het klankstelsel invloed van het Austronesisch heeft ondergaan, blijve aan Sinologen ter beoordeeling.

De woordenlijst toont bepaaldelijk een Austronesisch - in tegenstelling met een Austro-aziatisch - beeld. Ik ben daarom geneigd de vermenging latèr te stellen dan het uiteengaan van Austro-aziatische en Austronesische talen.

Leiden, 20 November 1942. 
370 WORTELS EN GRONDWOORDEN IN DE AUSTRONESISCHE TALEN.

\title{
INHOUDSOPGAVE.
}

\author{
Hoofdstuk I.
}

Blz.

Inleiding

Hoofdstuk II.

Affigeering . . . . . . . . . 279

Hoof dstuk III.

Herhaling en reduplicatie. . . . . . . . . 308

Hoofdstuk IV.

Grondwoorden met vóór-syllabe . . . . . . . . . . 332

Hoof dstuk V.

Prenasaleering

Naschrift. 